MARIA ISABEL BLANCO

\title{
Um documentário de afeto: espanhóis na cidade de São Paulo
}

Dissertação apresentada ao Programa de PósGraduação da Escola de Comunicações e Artes da Universidade de São Paulo, como requisito parcial para a obtenção do título de Mestre em Ciência da Comunicação. Área de Concentração: Estudos dos Meios e da Produção Midiática. Linha de Pesquisa: Técnicas e Poéticas da Comunicação. Orientador: Profa. Dra. Marília da Silva Franco 
MARIA ISABEL BLANCO

\section{Um documentário de afeto: espanhóis na cidade de São Paulo}

Dissertação apresentada ao Programa de PósGraduação da Escola de Comunicações e Artes da Universidade de São Paulo, como requisito parcial para a obtenção do título de Mestre em Ciência da Comunicação. Área de Concentração: Estudos dos Meios e da Produção Midiática. Linha de Pesquisa: Técnicas e Poéticas da Comunicação. Orientador: Profa. Dra. Marília da Silva Franco 
ASSINATURAS DOS MEMBROS DA COMISSÃO JULGADORA

Dissertação defendida em:

1 
A meu filho, João Pedro Arruda Blanco, aos meus pais, Cidinha Capellari Blanco e José Luis Blanco Goicoechea, aos meus irmãos e cunhados, Maria Cristina Blanco e Maurício Anaya e Carlos Enrique Blanco e Tânia Blanco, e ao ARUANDA LAB.DOC. 


\section{AGRADECIMENTOS}

À Profa. Dra. Marília Franco, pela orientação viva, pelo amor à construção do conhecimento e pela generosidade ao compartilhá-lo.

Aos Professores integrantes da banca de qualificação, Prof. Dr. Afrânio Catani e Prof. Dr. Eduardo Vicente, pelas críticas pertinentes no exame de qualificação.

Aos amigos do ARUANDA LAB.DOC, pelas reflexões elaboradas e compartilhadas e pelas amizades construídas.

À equipe de produção do exercício prático, pelo rico aprendizado e pela confiança na realização dos sonhos.

À minha família, pelo apoio constante.

Aos imigrantes espanhóis, com quem tenho aprendido muito sobre a vida, em especial a Carmen Acirón Rius, Margarita Riudoms Fernandez, Carmen Baena Fernandez e José Luis Blanco Goicoechea, pelas entrevistas concedidas e narrativas ricas.

Ao Centro Valenciano "La Senyera" de São Paulo, onde comecei aprender sobre os espanhóis.

Ao governo espanhol, por meio do Ministério do Trabalho e Imigração, que concedeu as ajudas para a produção do exercício prático.

Aos colegas profissionais, especialmente da TV Cultura, pelas conversas, preocupação e compromisso com a formação profissional.

Ao Carlos Wagner La-Bella (Waguinho), Ricardo Paoletti, Mariana Brasil e Laine Milan, pela confiança, respeito e oportunidade de crescimento profissional.

Às amigas Silvia Marques, Martha Rejane, Solange Martins e Marina Sú, sempre presentes. 


\section{RESUMO}

O indivíduo contemporâneo é fragmentado e possui múltiplas identidades. Quantas referências culturais uma pessoa pode ter? Como essas diferentes identidades convivem entre si? Esta pesquisa acadêmica teve por objetivo utilizar o documentário como meio constituinte e significante para a reflexão sobre a construção das identidades culturais de imigrantes espanhóis na cidade de São Paulo. Para tanto, produzimos um exercício prático em formato de documentário, acompanhado de uma análise que contempla a reflexão sobre o método de produção construído durante a realização do exercício. A reflexão foi feita a partir de aproximações de métodos de produção do antropólogo David MacDougall e dos realizadores Eduardo Coutinho e Trinh T.Minh-há. Do mesmo modo, servimo-nos de alguns postulados de coleta de depoimentos da História Oral, propostos por José Carlos Sebe Bom Meihy, e dos acercamentos às memórias pessoais estudados por Ecléa Bosi. Levou-se em consideração, ainda, a hipótese elaborada no contexto do laboratório Aruanda lab.doc. Esse grupo de pesquisas, que reflete sobre as diferentes formas de produção de audiovisuais de não-ficção, postula como hipótese que não há uma metodologia única ou unificadora para o documentário, na medida em que ele tem como princípio fundante o compromisso com o real. Isso obriga ao realizador que haja adaptações dos métodos planejados às condições de realização impostas pelo mundo histórico.

PALAVRAS-CHAVE: Documentário (filme). Método de produção audiovisual de não-ficção. Imigração. Identidade cultural. Linguagem audiovisual. Espanha. 


\begin{abstract}
The contemporary man is a fragmented being with multiple identities. How many cultural references can a person have? How those different identities interact? In this academic research, documentary film was used as means of constituency and significance of the construct of the cultural identities of Spanish immigrants in the city of São Paulo, Brazil. In order to achieve that, a practical exercise in a documentary film format was conducted, and a written discussion of the method of production elected for the practice was elaborated. The reflection is based on parallels with production methods from the anthropologist David MacDougall and the filmmakers Eduardo Coutinho and Trinh Minh-ha. The analysis also profits from the Oral History collection by José Carlos Sebe Bom Meihy and from Ecléa Bosi's approach to personal memories. Another source for this research was the set of hypothesis bring about in Aruanda lab.doc meetings. Aruanda is a research group, concerned with reflecting on the various forms of audiovisual production of non-fiction and documentary films. We share Aruanda's main research hypothesis is that no single or unifying methodology can account for a documentary film, due to the fact that the foundating principle of documentaries is the compromise with the world's concrete realities, which requires adaptations of the planned methods to the conditions imposed by the historic world.
\end{abstract}

KEYWORDS: Documentary film. Audiovisual non-fiction production method. Immigration. Cultural identity. Audiovisual language. Spain. 


\section{Caminante}

Caminante, son tus huellas el camino, y nada más; caminante, no hay camino, se hace camino al andar. Al andar se hace camino, y al volver la vista atrás se ve la senda que nunca se ha de pisar.

Caminante, no hay camino, sino estelas en la mar.

(Antonio Machado) 


\section{SUMÁRIO}

INTRODUÇÃO: O FAZER DOCUMENTAL

\section{CAPÍTULO 1 - REFERENCIAIS TEÓRICOS E DOCUMENTARISTAS DE}

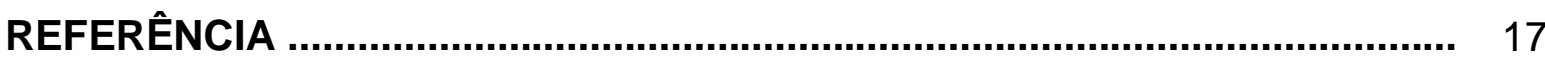

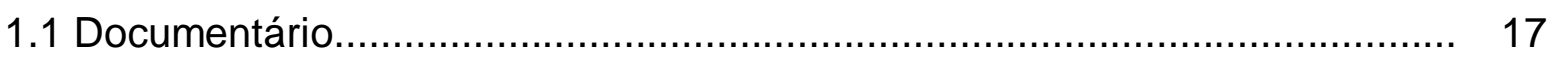

1.2 Relevância da imigração espanhola na cidade de São Paulo ..................... 20

1.3 Modelos de aproximação e proposta estética ........................................... 22

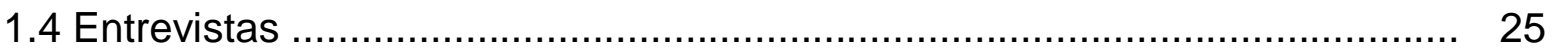

1.4.1 História oral como método de fundamentação ……................................ 25

1.4.2 Conceitos de fundamentação para entrevistas ....................................... 28

CAPÍTULO 2 - DUPLA PERSONALIDADE DO DOCUMENTÁRIO: A DO

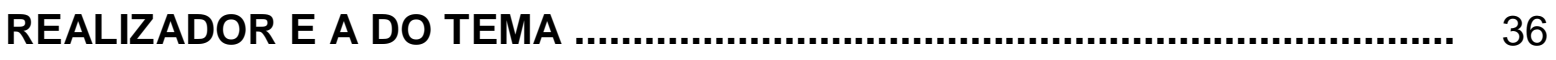

2.1 Abordagem pessoal ................................................................ 36

2.2 A viabilização da produção ........................................................... 39

2.3 Documentário: assistir, discutir, estudar, ensinar e, acima de tudo,

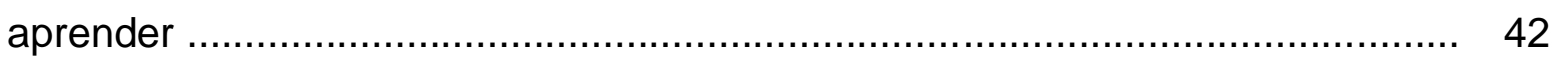

2.4 Vínculo ideológico com o documentário ................................................. 46

2.5 Desafios a serem enfrentados ........................................................ 48

2.6 Da Espanha e dos espanhóis ........................................................... 50

2.6.1 A maneira rude do ibérico ........................................................... 50

2.6.2 A Espanha revisitada ............................................................... 52

CAPITULO 3 - ENTREVISTADOS E DIRETORA - A APROXIMAÇÃO .......... 55

3.1 A construção dos vínculos com a comunidade valenciana .......................... 60

3.2 Momento significativo da participação política e aprendizagem do exercício

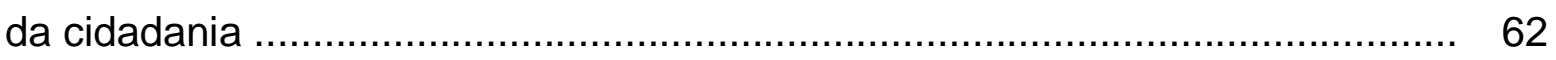

3.3 Início do processo de pesquisa dos personagens ..................................... 64

3.4 Escolha dos personagens - início da construção do discurso em formato

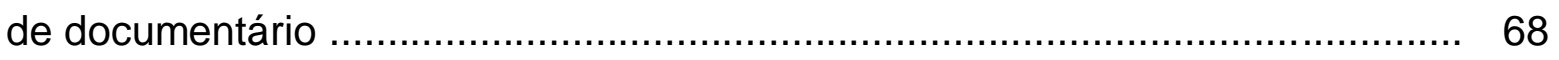

3.5 Percepção de se trabalhar com colaboradores - pré-entrevistas ................. 70 
3.6 Meus embates interiores

3.7 Perfis dos entrevistados escolhidos ..................................................... 78

3.7.1 Carmen Baena Fernandez ................................................................ 78

3.7.2 Mari Carmen Acirón Rius .................................................................... 83

3.7.3 Margarita Riudoms Fernandez ...................................................... 87

3.7.4 José Luis Blanco Goicoechea ......................................................... 89

CAPÍTULO 4 - O MÉTODO DA PRODUÇÃO …........................................... 91

4.1 Etapas do processo de produção e a ética do processo ............................ 91

4.1.1 Gerenciamento da produção ........................................................... 91

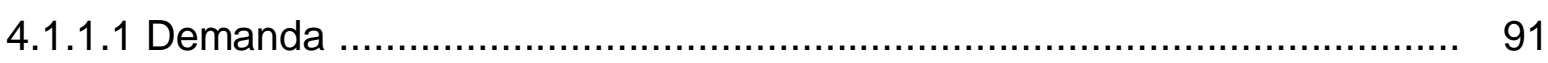

4.1.1.2 Financiamento ........................................................................ 91

4.1.1.3 A formação da equipe ................................................................. 92

4.2 Procedimentos de produção ………………...................................... 96

4.2.1 Pesquisas preliminares ................................................................ 96

4.2.2 Roteiro de gravação .................................................................. 100

4.2.3 Gravação das entrevistas ............................................................. 103

4.2.3.1. Primeira gravação - Mari Carmen Acirón Rius .................................. 106

4.2.3.2 Segunda gravação - José Luis Blanco Goicoechea ........................... 111

4.2.3.3 Terceira Gravação - Margarita Riudoms Fernandez .......................... 118

4.2.3.4 Quarta gravação - Carmen Baena Fernandez .................................. 125

4.2.4. Desenho sonoro ............................................................................ 129

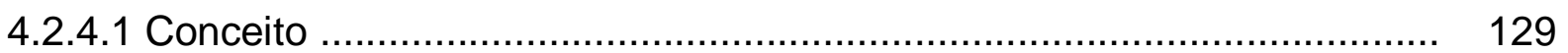

4.2.4.2. Procedimento de composição ........................................................ 131

4.2.5 Edição e montagem ...................................................................... 132

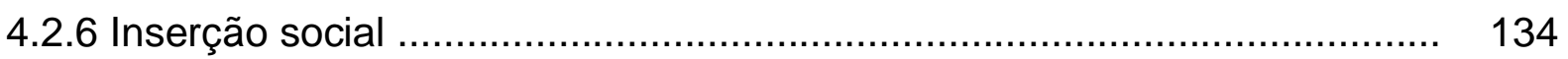

4.2.7 Procedimentos de produção que faltam para finalização do documentário 134

4.3 Interlocução do método documental construído com a experiência profissional de produtora de televisão......................................................... 136

4.4 Coautoria do trabalho coletivo e a relação entre a equipe de produção ....... 144

4.5 Autoria e generosidade - humildade em relação ao tema ........................... 152

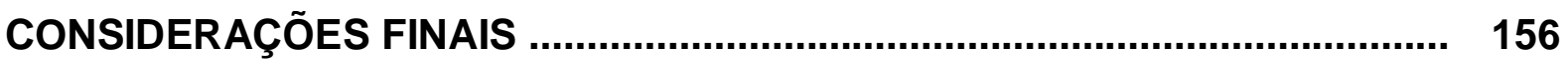




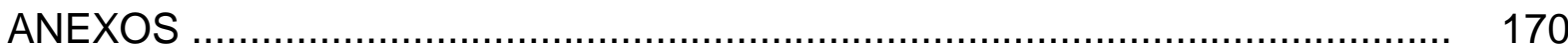

ANEXO A - Questionário de pré-entrevista - Carmen Baena Fernandez ......... 171

ANEXO B - Questionário de pré-entrevista - Mari Carmen Acirón Rius ........... 175

ANEXO C - Questionário de pré-entrevista - Margarita Riudoms Fernandez ... 178

ANEXO D - Questionário de pré-entrevista - José Luis Blanco Goicoechea .... 181

ANEXO E - Questionário das entrevistas para gravação ................................ 184

ANEXO F - Ordem do dia - primeira gravação - Mari Carmen Acirón Rius ...... 186

ANEXO G - Ordem do dia - segunda gravação - José Luis Blanco

Goicoechea

ANEXO H - Ordem do dia - terceira gravação - Margarita Riudoms

Fernandez

ANEXO I - Ordem do dia - quarta gravação - Carmen Baena Fernandez 


\section{INTRODUÇÃO: O FAZER DOCUMENTAL}

Este trabalho propõe a utilização do documentário como meio constituinte e significante para a reflexão sobre a construção das identidades culturais de imigrantes espanhóis na cidade de São Paulo.

A opção por esse objeto e essa forma de pesquisa pode ser explicada sob diferentes aspectos de minha vida. É um desafio e uma proposta de construção de conhecimento nos âmbitos profissional, acadêmico e pessoal.

\section{Profissional}

Profissional porque parto de meu lugar de formação - a produção audiovisual - por meio da qual manifesto todo o meu amor pelo cinema e pela televisão, ambiente onde atuo com toda a minha criatividade e expressão artística.

Atualmente, exerço a função de coordenadora de pós-produção na TV Cultura de São Paulo. Essa trajetória iniciou-se no ano de 1993, quando trabalhei na produtora independente Vídeo \& Companhia Ltda como assistente de produção. A mim cabia a responsabilidade de coordenar a edição dos programas e dar assistência à produção de base da coordenação de produção.

Em 1994, comecei a atuar como pesquisadora audiovisual para o programa Telecurso 2000, hoje renomeado como Novo Telecurso, realizado pela Fundação Roberto Marinho e FIESP (Federação das Indústrias do Estado de São Paulo). Os quatro anos em que exerci essa função foram um período muito proveitoso, pois, no ambiente de uma equipe de produção de ficção (e não-ficção), similar às estruturas de produção de telenovelas, aprendi muito com profissionais experientes. 
Com o diretor Carlos Nascimbeni e com a coordenadora Áurea Gil, pude aprender a pesquisar textos, imagens e sons, a sistematizar as informações para fácil recuperação (constituição de um banco eletrônico audiovisual) e pude perceber as formas de utilizar melhor esses materiais nas gravações e nas edições. Desenvolvemos, portanto, uma metodologia de pesquisa audiovisual que atendesse às necessidades do projeto.

O rigor no trabalho conduzido em cada etapa foi também um aprendizado precioso, de que me utilizo sempre na vida profissional e que também me acompanha nas atividades acadêmicas. Além da pesquisa audiovisual, conheci as sistemáticas e estratégias de direção e produção que se estabeleceram no contexto do trabalho do Telecurso 2000.

Com Nascimbeni, trabalhei por dez anos. Depois de terminar a produção do Novo Telecurso, em 1998, produzimos outras séries mais curtas de programas de teleducação, em que exerci diferentes funções: produtora, assistente de edição, assistente de direção e coordenadora de produção. Sem dúvida, devo a ele muitos dos conhecimentos construídos. Sinto-me orgulhosa e grata por ter compartilhado momentos profissionais de tamanha relevância.

A experiência profissional adquiriu maior amplitude e aprofundamento quando fui trabalhar, a convite de Carlos Nascimbeni, na TV Cultura de São Paulo, em 2001. Por meio da integração profissional entre as áreas de produção e de programação, constatei o que significa a produção ter a responsabilidade de assumir a exibição periódica de um programa. Na televisão, a grade de programação determina o ritmo e o método de produção. Em suma, ela gerencia a produção.

No ano de 2007, ainda na TV Cultura, recebi a proposta de constituir e coordenar o núcleo de pós-produção. O trabalho consiste na criação de sistemáticas 
e fluxos de informações, além da avaliação audiovisual de programas prontos, produzidos por parceiros da TV Cultura.

\section{Acadêmico}

Há alguns anos (2004), quando voltei a estudar como aluna especial da disciplina de pós-graduação da Profa. Dra. Marília Franco - "Audiovisual de nãoficção: na transversal da imagem" -, refleti sobre minha formação e compreendi a riqueza de sua natureza híbrida: aprendi sobre produção com um diretor; portanto, tenho muito de produtora e boa parte da mentalidade de diretora.

$\mathrm{Na}$ graduação em Comunicação Social, especializei-me em jornalismo. Formada pela UFPB (Universidade Federal da Paraíba), tive a oportunidade de ser aluna de Linduarte Noronha e Vladimir Carvalho. Imersa no ambiente da rica tradição documentarista paraibana, tive os primeiros contatos com o universo do documentário paraibano e brasileiro ao longo de todo o curso, pois na universidade havia profissionais que valorizavam e divulgavam a produção desses documentaristas consagrados. Vez por outra, promoviam mostras, debates e projeções da filmografia que fazia parte do acervo do departamento. Sempre que podia, frequentava essas seções; pareciam-me muito mais interessantes do que os conteúdos das aulas sobre o jornalismo funcionalista postulado no curso: os leads e sub-leads.

Mal podia imaginar que aquele período de ávido descobrimento e conhecimento sobre a cultura paraibana e nordestina, apreendida também por meio dos documentários, fosse o início da paixão e da criação de vínculos ideológicos com o próprio documentário. Aqueles anos serviram de fundamentação para o que 
viria a se transformar, vinte anos mais tarde, em meu objeto de pesquisa de mestrado. Na esfera da pesquisa acadêmica, essa experiência significa construir aprendizagem da metodologia de pesquisa científica e da escritura da dissertação.

Esta dissertação contempla a reflexão sobre o método de produção construído. Reflexão iluminada pelas aproximações com métodos de produção de Eduardo Coutinho e de antropólogos/realizadores e pela hipótese elaborada no contexto do laboratório Aruanda lab.doc., grupo de pesquisas, reflexão e produção de não-ficção. Tal hipótese postula que, para o documentário, que tem como condição fundante o compromisso com o real, com o mundo histórico, não há uma metodologia unificadora.

No aspecto prático e profissional da pesquisa, apresenta-se o desafio da produção independente de gravações de entrevistas, em formato de documentário, com o lastro também acadêmico. Todas experiências inéditas, até então, para mim.

\section{Pessoal}

A vivência pessoal entra como elemento significativo e singular na escolha do tema do documentário. Sou filha de pai espanhol e mãe brasileira com ascendência italiana. Desde minha infância, convivo com culturas diferentes e identidades culturais que vêm se construindo ao longo do tempo.

Hoje posso me considerar uma profissional curiosa, que resolveu problematizar questões pessoais estruturando-as em forma de projeto de pesquisa. Tal curiosidade tem me acompanhado ao longo dessa trajetória e se manifesta, principalmente, pelo questionamento de ordem filosófica, psicológica e cultural sobre a vida e sobre as nuances que a existência humana pode adquirir. 
Um dos desafios é transcender a esfera da história pessoal, por meio de um exercício de memória coletiva, e contar parte da história pública de um número significativo de espanhóis que vieram para São Paulo em busca de um sonho, de uma vida melhor.

Essa experiência se realizará por meio de entrevistas com imigrantes espanhóis, daí a produção de um exercício em formato de documentário, articulando e aperfeiçoando minha experiência profissional.

A convivência com culturas diferenciadas tem me propiciado questionamentos que sempre me instigaram: por que as pessoas sentem necessidade de saírem de seus lugares de origem? Por que conhecer outros povos? Como se constroem as relações e negociações com pessoas de culturas diferentes da nossa? E as identidades culturais? Como se constroem?

Com a oportunidade de realizar a pesquisa e a produção de um exercício prático documental, resolvi investigar essas questões tão íntimas, tão caras e tão presentes na minha existência. Devo admitir que as múltiplas facetas desses questionamentos não têm sido de fácil manejo para mim, pois acredito que a questão da construção e articulação das múltiplas identidades na contemporaneidade se apresenta como "a dor e a delícia". Dor devido às dificuldades em lidar com a alteridade e delícia pelas benesses - trocas culturais e enriquecimento humano nessa lida - que essas relações nos proporcionam.

Portanto, sinto-me imersa em uma experiência de deslocamento cultural termo caro aos antropólogos -, ou, se preferirem, na metáfora de uma viagem cultural com diferentes perspectivas: na vida pessoal e na vida profissional. E como uma viajante, ou melhor, caminhante, de acordo com o poeta espanhol Antonio Machado, convido o leitor a compartilhar essa trajetória comigo. 


\section{CAPÍTULO 1}

\section{REFERENCIAIS TEÓRICOS E DOCUMENTARISTAS DE REFERÊNCIA}

\subsection{Documentário}

A tentativa de definição de documentário tem recebido diferentes conceituações, de acordo com Penafria (1999), que vão desde aquelas que o circunscrevem a questões sociais até às que pretendem diferenciá-lo dentro da linguagem cinematográfica. (PENAFRIA, 1999, p. 30). O autor afirma que tais definições de documentário nunca foram pacíficas, por empregar conceitos como os de realidade, autenticidade ou fato.

Bill Nichols (2005) postula que o documentário não é uma reprodução da realidade, mas uma representação do mundo em que vivemos. Para refletir sobre a problemática, propõe uma compreensão por quatro ângulos diferentes: o das instituições, o dos profissionais, o dos textos (filmes e vídeos) e o do público. (NICHOLS, 2005, p. 59).

A partir das perspectivas sob o ângulo dos textos, o autor comenta acerca dos recursos estilísticos das diferentes estruturas narrativas. Ele postula que os documentários apóiam-se muito na palavra dita, expressa por meio de narradores, atores sociais nas entrevistas, ou no que os atores sociais dizem entre si. (NICHOLS, 2005, p. 59).

A ampla utilização da palavra dita (entrevista) como recurso narrativo do documentário no Brasil dá-se a partir dos anos 1960. Segundo D’Almeida (2006), nessa época surgiu um estilo novo, que incorporava as inovações tecnológicas a 
ele. Nesse período, a banda sonora adquiriu a mesma importância da banda visual do filme. (D'ALMEIDA, 2006, p. 02)

No contexto da produção documental brasileira, Eduardo Coutinho valeu-se do novo estilo, privilegiando a palavra dita. Desenvolveu um método de produção a ponto de consagrar-se no manejo da entrevista como princípio fundante da narrativa em Santo Forte (1999).

\begin{abstract}
O filme que só Coutinho podia e queria fazer se baseava essencialmente na fala dos personagens. Suas realizações anteriores levaram-no - por caminhos muitas vezes tortuosos - a essa opção. Por intuição e por reflexão decidiu, em Santo Forte, assumir de vez a depuração gradual de muitos elementos estéticos que havia efetuado ao longo de seus documentários e se concentrar no fundamental: o encontro a fala e a transformação dos personagens. (LINS, 2007, p. 98).
\end{abstract}

Para Coutinho, a entrevista é denominada como fabulação e tem, na escuta ativa, um dos elementos característicos de sua direção.

"Se eu digo que o meu desejo é só escutar, não há filme, não é assim. Se há um lado passivo na interlocução, acabou. Os dois lados (entrevistador e entrevistado) devem estar ativos". (LINS, 2007, p. 109).

D’Almeida (2006) postula que a entrevista é uma técnica, um mecanismo de troca de subjetividades, em que um dos elementos envolvidos, o entrevistador, se "abre" para receber o outro. Segundo ele, o que está em jogo são interpretações da verdade, sentimentos e sensações, visões de mundo diferentes e singulares, não o saber objetivo, positivo e fechado em si mesmo. (D'ALMEIDA, 2006, p. 05).

No contexto desse mecanismo de troca de subjetividades, Coutinho desenvolve o foco de seu trabalho de documentarista na construção dos personagens. Segundo sua concepção, as pessoas são tão naturais quanto artificiais em seu cotidiano. Coutinho questiona o processo que a pessoa desenvolve 
para atingir essa naturalidade e termina por afirmar que se trata da "mentira verdadeira". (LABAKI, 2005, p. 119).

Assim, na concepção de Coutinho, no momento da entrevista, o que lhe interessa, segundo Lins (2007), é a construção imaginária das pessoas a partir do real, cujos aspectos ficcionais são muito mais reveladores do personagem do que uma pretensa adequação ao que a pessoa é "de verdade" no cotidiano. (LINS, 2007, p. 113).

D’Almeida postula a característica própria da entrevista no documentário:

As entrevistas no documentário se configuram como o espaço do drama por excelência. É na imprevisibilidade de um drama sem roteiros, que falas fragmentadas, silêncios expressivos, sensações e sentimentos discordantes, avaliações disparatadas e gestos nervosos geram o sentido. Nas entrevistas não são propriamente as pessoas que aparecem na tela, mas as personagens criadas e delineadas pelo e no encontro com 0 cineasta, em presença da câmera. (D'ALMEIDA, 2006, p. 05).

Concordo com D’Almeida sobre o atributo da entrevista, no documentário, de constituir-se como o cenário onde acontece a construção do personagem em duas perspectivas: da pessoa que se constrói e da que é construída pelo diretor.

Esse exercício prático tem como proposta a gravação de entrevistas, em formato de documentário, com imigrantes espanhóis narrando episódios significativos de suas histórias de vida. O foco do documentário é a reflexão acerca da construção de suas identidades culturais. Tal tema foi estabelecido por três demandas: relevância em minha busca pessoal e de minha identidade cultural; por se constituir em objeto de estudo de mestrado e pelo aprendizado da produção documental em interlocução com a minha experiência profissional.

Proponho a aproximação ao método de produção de Coutinho, na medida em que a constituição do eixo narrativo se estabelece por meio das entrevistas e na medida em que o momento de maior relevância no processo de produção do filme 
documentário, concebido nesse estilo, acontece no encontro - denominado por mim encontro e embate - com o outro.

A escolha de estudar a temática da imigração espanhola deve-se à relevância da participação do imigrante espanhol na constituição socioeconômica da cidade de São Paulo e ao ineditismo da produção documental sobre o tema.

\subsection{Relevância da imigração espanhola na cidade de São Paulo}

A imigração espanhola no Brasil teve dois períodos significativos, segundo Klein (1994). O primeiro, de 1885 a 1930, registra a chegada de cerca de 550 mil espanhóis ao Brasil, com destino às cidades do interior paulista para servirem de mão de obra à cafeicultura.

O segundo fluxo, compreendido entre 1946 e 1970, contou com a chegada de 130 mil espanhóis (KLEIN, 1994, p. 36), cujo destino era a cidade de São Paulo e a região do $A B C$ (São André, São Bernardo e São Caetano), e grande parte desta população veio para atender à necessidade de mão-de-obra da indústria. O grupo de imigrantes espanhóis pesquisado corresponde ao segundo fluxo, pois é composto por imigrantes residentes na cidade de São Paulo.

A dinâmica constante dos fluxos migratórios desde o segundo período até os dias atuais não permite o refinamento de informações estatísticas sobre a quantidade de imigrantes espanhóis residentes no Brasil, principalmente por parte das instituições espanholas, pois as estimativas partem dos consulados para o governo central na Espanha. Nos deslocamentos migratórios, há muitos cidadãos inscritos em determinada zona consular que não comunicam oficialmente sua mudança, quando ela ocorre. Outra situação, mencionada por Arturo Maciera Chao 
(presidente do Conselho de Residentes Espanhóis - CRE -, em São Paulo) são as mortes, que, eventualmente, não são comunicadas aos consulados, fato que contribui para se questionar a credibilidade dos indicadores.

Os espanhóis que compõem tais indicadores são apenas aqueles registrados nos consulados pelo Departamento de Registro Civil. Segundo o PERE (Padrón de españoles residentes em el extranjero) de 1 de janeiro de 2009, há, no Brasil, 78 mil espanhóis de todas as idades ${ }^{1}$. Segundo informações de Francisco José Javier, funcionário do Consulado General de España em São Paulo, há um número expressivo (não estimado) de espanhóis residentes no Brasil, que, entretanto, não possuem registro civil nos consulados. Portanto, não compõem esses indicadores. (informação verbal) $^{2}$

Outro componente a se considerar é a concepção do conceito de cidadania espanhola no exterior, como parte integrante do Estatuto da Cidadania Espanhola no Exterior, Lei no 40/2006, de 14 de dezembro de 2006. O estatuto normatiza os direitos e deveres dos emigrantes espanhóis, atribuindo-lhes o mesmo status de cidadania dos espanhóis que vivem no país. Desde então, o governo espanhol tem sancionado leis que dizem respeito ao direito de cidadania aos descendentes (Lei no 03/2005 de los niños de la guerra e Lei no 52/2007 da memória histórica). Isso significa que, a partir das promulgações dessas leis, tem havido aumento considerável no número solicitações de registros civis de espanhóis na Espanha e no exterior. Tal dinamismo da situação torna difícil o controle, atualização e acompanhamento dos indicadores por parte dos órgãos instituídos.

Além das divergências entre indicadores e do dinamismo social no contexto espanhol, há disparidade entre indicadores espanhóis e brasileiros. Segundo o

\footnotetext{
${ }^{1}$ Dado obtido no site: <http://www.ine.es/jaxi/menu.do?type=pcaxis\&path=/t20/p85001/a2009\&file=pcaxis >. Acesso em: 5 jan. 2009.

${ }^{2}$ Informação fornecida por Francisco José Javier em janeiro de 2009.
} 
Ministério da Justiça, há uma população de 60 mil espanhóis vivendo atualmente no Brasil $^{3}$. Portanto, não há possibilidade de compor apenas um indicador que represente o número real de espanhóis no Brasil.

\subsection{Modelos de aproximação e proposta estética}

Juntamente com as entrevistas, há uma proposta estética para o documentário, que prevê a utilização de recursos estilísticos reflexivos, por meio de gravações das cenas de construções dos personagens e interação com a equipe. Tais cenas têm o objetivo de revelar ao público as nuances acerca dos entrevistados, construindo-se como personagens e sendo construídos por mim no documentário, bem como eventualmente revelar a equipe de produção, de acordo com o método de Eduardo Coutinho.

Propus também uma aproximação ao método de produção de realizadores de documentários antropológicos por meio do tratamento do tema, no que diz respeito à aproximação aos entrevistados/personagens: convivência de longo período com o grupo a fim de estabelecer vínculos, conhecimento e confiança para a realização da gravação.

Outra proposta de aproximação ao método de produção do documentário antropológico é a concepção do documentário em seu aspecto relacional. MacDougall (1995) postula, assim como Coutinho, este aspecto da produção de documentários etnográficos:

\footnotetext{
${ }^{3}$ Dado obtido no site: < http://www.jusbrasil.com.br/noticias/1495507/lula-anistia-estrangeiro-que-vive-emsituacao-irregular >. Acesso em: 21 jul. 2009.
} 
No ethnography film is merely a record of another society: it is always a Record of the meeting between a filmmaker and that society. If ethnographic films are to break through the limitations inherent in their present idealism, they must propose to deal with that encounter. Until now they rarely acknowledged that an encounter has taken place (cf. McCarty's paper, supra). (MACDOUGALL, 1995, p. 125).

O aspecto relacional do documentário tem na entrevista o ambiente que abriga os encontros e embates. D'Almeida concebe essa oportunidade para o estabelecimento do diálogo como alternativa possível, além da relação assimétrica de poder.

É na relação com o outro, no diálogo, que se podem compreender as dimensões simbólicas da ação social e a lógica informal da vida real. Isso implica a articulação ou a confrontação permanente dos horizontes de entrevistador e entrevistado. O resultado é um saber negociado, que integra o saber de um ao saber do outro. (D'ALMEIDA, 2006, p.10).

Coutinho, por sua vez, com a experiência de documentarista e com o método constituído a partir do encontro, assume a reflexão de forma assertiva, no que diz respeito ao momento do encontro do diretor com os entrevistados.

Portanto o fundamental do documentário acontece no instante do encontro ou não acontece. E se não acontece não tem filme. $E$ como você depende inteiramente do outro para que aconteça algo, é preciso se entregar para ver se acontece. (LABAKI, 2005, p. 121).

Trinh T. Minh-há, documentarista e pesquisadora vietnamita, propõe, na relação do diretor com o outro, o "falar de perto" - speaking nearby - em contraposição à postura clássica dos documentaristas, que, segundo ela, "falam sobre" - speak about. Segundo Sklair (2006), "o falar sobre somente compartilha da conservação de sistemas de oposição binária": sujeito/objeto; eu/eles; nós/eles. (SKLAIR, 2006, p. 139). Para Sklair, essa concepção assegura a posição de dominação para aquele que fala, pois vem carregado de camadas de pressupostos, implicações e jogos/demonstrações de poder. 
Propus a aproximação ao "falar de perto", da diretora vietnamita, desde o processo de construção das relações com os entrevistados até o momento das gravações das entrevistas, pois concordo com o questionamento dela acerca da relação assimétrica de poder estabelecida entre diretor e entrevistados.

A transposição audiovisual do "falar de perto" terá, na linguagem da câmera móvel, sua expressão maior durante as sequências denominadas "memória afetiva", em que o entrevistado apresenta pessoas e fotos que fazem parte de sua vida, e na sequência dos "objetos biográficos", que revela as histórias e relações dos entrevistados com esses objetos.

A linguagem compreende movimentos suaves, muitas vezes próximos (em planos fechados e detalhes), ou em panorâmicas, que revelam ambientes, os símbolos culturais e os entrevistados na narração das relações afetivas com os objetos biográficos.

Tenho como hipótese de pesquisa a possibilidade de estabelecer uma relação dialógica entre diretor e entrevistado, plasmada pelo respeito e afeto humanos. Estabelecimento este que se constrói por meio da abertura para o diálogo entre ambos. Conforme D'Almeida,

As tensões do encontro permanecem, mas a assimetria é compensada por uma abertura efetiva para o diálogo, pela disposição da escuta e pela consciência de que a situação está sendo filmada, de que há uma mise-enscène, um contexto e de que haverá uma montagem. (D'ALMEIDA, 2006, p. 10).

O exercício prático produzido teve como proposta a fundamentação da concepção relacional da produção documental, concebida por Coutinho e MacDougall: documentário é o encontro com o outro. De acordo com Coutinho, pretendi utilizar a entrevista como princípio fundante do eixo narrativo. 
A entrevista, concebida por D'Almeida como o espaço do drama e onde o personagem se constrói e é construído pelo diretor, é o momento de maior relevância, em que acontece o encontro entre diretor e entrevistados.

Proponho, segundo D'Almeida, no momento da entrevista, do embate, o estabelecimento de uma relação fundamentada na abertura, respeito e afeto, bem como a construção das relações desde o processo inicial da produção.

A aproximação à concepção de Trinh T. Minh-há se expressará com o "falar de perto", na relação com os entrevistados, e na transposição audiovisual do conceito, nas sequências (memória afetiva e objetos biográficos) da câmera móvel, a fim de registrar momentos da cultura subjetiva dos personagens.

\subsection{Entrevistas}

\subsubsection{História oral como método de fundamentação}

Os métodos de trabalho desenvolvidos em história oral, que conheci por meio da disciplina "História oral, memória e relações disciplinares", ministrada pelo Professor Dr. José Carlos Sebe Bom Meihy, foram adotados como fundamento de meus procedimentos de direção, na elaboração e realização das entrevistas, pois sua conceituação e produção apresentam pontos de semelhança com a natureza do trabalho de produção do documentário proposto.

Há vários conceitos para a história oral, dentre eles pode-se destacar o que a relaciona a uma prática de apreensão de narrativas feitas por meio do uso de meios eletrônicos e destinada a recolher testemunhos, promover análises de processos sociais do presente e facilitar o conhecimento do meio imediato. (MEIHY, 2002, p. 13). 
A opção pela história oral de vida se deu porque ela privilegia o colaborador (entrevistado) na entrevista, que precisa ter liberdade para narrar sua experiência pessoal. Portanto, o conteúdo relevante nas narrativas não se constitui da verdade, mas dessas experiências, cuja versão é tratada sob a perspectiva da moral existencial.

O fato de essa categoria de história oral trabalhar com a experiência de vida, segundo Meihy (2002), possibilita a compreensão do espaço pessoal subjetivo. Portanto, o eixo da narrativa é construído por meio de impressões, sentimentos e sonhos.

O estatuto atribuído para a história oral no contexto da produção do documentário foi o de um método de trabalho, pois conforme Meihy:

"Como método a história oral se ergue segundo alternativas que privilegiam os depoimentos como atenção central dos estudos. Trata-se de focalizar as entrevistas como ponto central das análises." (MEIHY, 2002, p. 44).

A história oral, na fundamentação do método, iluminou a constituição da narrativa do documentário construído por meio de entrevistas. De acordo com os pressupostos da história oral, a entrevista foi tratada por mim sob duas perspectivas: uma que diz respeito à minha relação com os entrevistados e a outra como concepção do momento da entrevista. A relação do oralista com os entrevistados, que a história oral denomina "colaboradores", pressupõe uma relação dialógica e amigável.

Meihy alerta para que o oralista - no meu caso, diretora - tenha uma paciência devocional para se estabelecer a relação entre os dois. Segundo ele, a entrevista é um jogo de poder, mas também deve-se ter o cuidado intimista no momento da gravação e aceitar que, como a história oral opera o tempo todo com a 
alteridade, faz-se necessário reconhecer e aceitar o outro (informação verbal) ${ }^{4}$. Na relação com os entrevistados, há um componente que a história oral tem como matéria-prima: lidar com a história de vida e com colaboradores.

No documentário, os entrevistados narraram suas experiências de vida, seu processo de imigração, adaptação à nova cultura no Brasil e constituição de suas famílias em solo estrangeiro.

Foram processos que implicaram situações vivenciadas no passado e no presente. $\mathrm{O}$ acesso ao passado e ao presente estabeleceu-se por meio de suas memórias e lembranças. Segundo Meihy (2002), a memória, a imaginação e a representação são bases que sustentam qualquer narrativa sobre o passado e o presente.

Assim como a história oral, o documentário trata a memória como via de acesso às narrativas dos entrevistados. Meihy (2002) alerta-nos acerca dos cuidados para operar com a memória, cuja característica é ser fluida e fragmentada:

Ao contrário de Freud, Maurice Holbwachs advoga que toda memória é sempre um produto social. Para ele a memória pessoal é uma retomada de outras memórias, anteriores, projetadas na vida comunitária de uma coletividade. Nesse caso, memória seria sempre uma fração, um fragmento gerado pela memória de um grupo submetido à mesma orientação cultural. (MEIHY, 2002, p. 45).

Portanto, no momento da entrevista foi considerado o trabalho da memória: o processo de seleção do que lembrar implica o que se esquece. A relação do esquecimento com a memória é vital para a compreensão dos resultados propostos pela história oral. (MEIHY, 2002, p. 67). Além desse aspecto, a memória tem características fluidas, conforme acentua Meihy: dinâmica, seletiva e não se repete. Nela estão contidos os sonhos, as fantasias, a criação e as distorções. (informação

\footnotetext{
${ }^{4}$ Informação fornecida pelo Professor Dr. José Carlos Sebe Bom Meihy, na disciplina "História Oral, memória e relações disciplinares", cursada no primeiro semestre de 2007.
} 
verbal $)^{5}$. Essa caracterização iluminou minhas estratégias na interação com os entrevistados no momento das gravações.

Essa concepção do momento da entrevista na história oral é diferente das concepções até então conhecidas por mim, na prática de produtora audiovisual e na formação de jornalista. Prática essa que se restringe à pesquisa superficial sobre o tema e o entrevistado e à elaboração de pauta, que, muitas vezes, conduz ou induz às respostas necessárias preestabelecidas pela linha editorial do programa.

Mas, na história oral, Segundo Meihy, o momento da entrevista significa uma comunhão entre entrevistado e entrevistador. Representa um momento peculiar a ponto de ser consagrado. (informação verbal).

$\mathrm{Na}$ relação com os entrevistados do documentário, as características da comunhão e do respeito, por meio de uma relação dialógica e amigável, se constituíram em princípios de minha postura ética e estiveram presentes durante todos os momentos da interação (embate e encontro). Esses momentos pressupõem o período de aproximação, pesquisa de personagens e gravações das entrevistas.

\subsubsection{Conceitos de fundamentação para entrevistas}

A pesquisa acerca dos conceitos de identidade cultural e cultura fundamentaram a elaboração dos temas e perguntas das entrevistas.

Os temas das entrevistas contemplaram as etapas significativas das trajetórias de vida dos entrevistados: origem dos imigrantes, a imigração, a viagem, da tradição aos novos costumes, questões de identidade cultural e estabelecimento

\footnotetext{
${ }^{5}$ Anotações de sala de aula durante a disciplina ministrada por José Carlos Sebe Bom Meihy, no primeiro semestre de 2007: "História oral, memória e relações disciplinares".

${ }^{6}$ Cf. nota 5 .
} 
da vida no Brasil. Além da formulação dos temas e perguntas para entrevista, a fundamentação teórica orientou-me nos encaminhamentos de assuntos novos, mencionados pelos entrevistados durante as gravações.

O conceito de identidade foi pesquisado sob a perspectiva contemporânea. Castells (2003) concebe a identidade como fonte de significado para os próprios atores (sociais), por eles originada e construída por meio de um processo de individuação. Para Castells, esse processo se constrói no contexto da sociedade cujas relações sociais encontram-se organizadas em rede.

Hall (2000) postula que, no mundo contemporâneo, o indivíduo possui, simultaneamente, várias identidades, promovendo a fragmentação do indivíduo anteriormente concebido como unificado.

Canclini (1999) desenvolve a concepção das múltiplas identidades contextualizando-as nas sociedades contemporâneas, em especial as latinoamericanas. Ele destaca a hibridização da cultura de tais sociedades. Assim, afirma que a identidade, mesmo em setores populares, é poliglota, multiétnica, migrante e composta por elementos mesclados de várias culturas.

Gioielli (2006), por sua vez, concebe como hipótese de seu trabalho a identidade líquida. Segundo ele:

A hipótese com a qual irá se trabalhar ao longo dessa dissertação é a de que, em meio às transformações do mundo contemporâneo, a identidade tornou-se líquida. Marcada por uma instabilidade acentuada tornou-se algo mole, fluido, capaz de assumir qualquer e variadas formas com imensa rapidez. (GIOIELLI, 2006, p. 24).

E essa identidade, denominada líquida, é construída socialmente:

... percebeu-se que toda identidade é produzida socialmente por meio de uma atividade discursiva, imaginária. Trata-se de uma construção cultural. É algo, portanto, que está sujeito aos jogos de linguagem, à mudança e às relações desiguais de poder que marcam a vida social. (GIOIELLI, 2006, p. 71). 
Os autores contemporâneos não concebem o indivíduo como uno, mas como portador de múltiplas identidades. Concordo com Gioielli na menção das identidades culturais como elementos integrantes no contexto da cultura e, por essa natureza, recebem as ressonâncias da dinâmica que a constitui.

Novaes (1993) traz a perspectiva antropológica contemporânea no que diz respeito à interação de diferentes grupos sociais no contexto da cultura dinâmica:

A situação de contato com outros grupos se permite perceber não como a destruição de modos tradicionais de vida, mas como um processo que leva à construção de um novo estilo de vida, com novas estratégias e alternativas, onde a cultura tem uma dimensão essencialmente dinâmica e adaptativa. (NOVAES, 1993, p. 42).

Estou de acordo com Novaes na concepção da cultura como contexto dinâmico. Essa concepção é compartilhada por Noval (1972). Para ele, a cultura vem do passado, vai em direção ao futuro e geralmente é um processo contínuo, apesar das mudanças que sofre. Ele reitera a noção de que a cultura é ensinamento e aprendizagem.

Gioielli (2006) apresenta a concepção de cultura como mediadora da identidade.

\footnotetext{
A cultura, enquanto o conjunto dinâmico de significados sistematizados, socialmente reconhecidos pelo coletivo, torna-se então, a mediação primordial de toda experiência de identidade. É por isso que se pode falar em uma identidade cultural. (GIOIELLI, 2006, p. 116).
}

Concordo com Gioielli ao mencionar a cultura como contexto mediador da identidade, lugar onde é construída socialmente.

Com relação às concepções de identidade concordo com Hall (2000) quando afirma que o indivíduo contemporâneo possui múltiplas identidades. Igualmente, concordo com Gioielli (2006) quando atribui à identidade a característica fluida, líquida, marcada pela instabilidade do mundo contemporâneo. 
Por meio das entrevistas gravadas, tenho constatado, conforme Gioielli (2006), que a cultura é mediadora da experiência da identidade cultural. Os entrevistados narram que, desde sua chegada ao Brasil, vêm estabelecendo negociações de adaptação à cultura brasileira, ao mesmo tempo em que constroem e reconstroem cotidianamente a cultura herdada.

Nas gravações das entrevistas, considerei a memória como a via de acesso às narrativas dos entrevistados. A história oral, por sua vez, constitui-se como método para as gravações das entrevistas e também opera com a memória. Portanto, o conceito de memória iluminou minha atuação como diretora e entrevistadora.

Um aspecto importante no perfil dos entrevistados reside no fato de que são pessoas da terceira idade e convivem no ambiente familiar de suas residências. Desta forma, suas vidas acontecem, em grande medida, no interior das residências. Por isso optei em gravar as entrevistas nessas locações.

O interior do lar das pessoas está configurado de tal forma, que os ambientes expressam muito de suas personalidades, ao abrigarem seus móveis e objetos de estimação. Bosi (2003) nomeia esses objetos como biográficos. Segundo a autora, são objetos que envelhecem com o possuidor e se incorporam à sua vida. Ela acrescenta que são objetos de valor espiritual, não material.

A proposta da gravação das entrevistas nas residências das pessoas teve o objetivo de revelar os ambientes de convivência, a decoração dos interiores, os símbolos culturais existentes e os objetos biográficos. Por meio da narrativa acerca dos objetos biográficos conhecemos parte da história afetiva de cada entrevistado.

Para expressar, do ponto de vista audiovisual, as narrativas afetivas acerca dos objetos biográficos, escolhi a linguagem da câmera móvel, preferencialmente. 
Entretanto, por força das circunstâncias, na gravação da entrevista de José Luis, a sequência dos objetos biográficos foi gravada com a câmera fixa.

De acordo com o perfil dos entrevistados, as memórias narradas têm suas especificidades: são memórias de velhos, conforme nomeia Bosi (1994). Ela menciona a característica própria dessa memória.

Ao lembrar o passado ele não está descansando, por um instante, das lides cotidianas, não está se entregando fugitivamente às delícias do sonho: ele está se ocupando consciente e atentamente do próprio passado, da substância mesma da sua vida. (BOSI, 1994, p. 60).

Considerando que, ao narrar suas memórias, o velho realize o trabalho do narrador, Bosi o considera um mestre do ofício:

Ele tem o dom do conselho. A ele foi dado abranger uma vida inteira.Seu talento de narrar lhe vem da experiência; sua lição ele extraiu da própria dor; sua dignidade é a de contá-la até o fim, sem medo. (BOSI, 1994, p. 90).

Portanto, os momentos das narrações durante as entrevistas não foram momentos de leveza e descanso. Foram carregados de emoções (alegrias e tristezas), de trabalho incessante da memória.

O trabalho do narrar, do contar, representa criação. Segundo Bosi (2003), o narrador realiza uma ordenação pessoal das lembranças que obedece a uma ordem afetiva, não cronológica. Por isso, constatamos, nas gravações, que as narrativas não são lineares e cronológicas.

Identifiquei o trabalho da memória nas narrativas como um movimento de avanço e retrocesso no tempo. Por várias vezes, uma entrevistada iniciava uma resposta e em seguida mudava de assunto. Eu não a interrompia. Ela se desviava da resposta inicial.

Várias vezes, se perdia e se dava conta. Diante da câmera, comentava sobre sua digressão. Outras vezes, se esquecia de fatos que sabia de cor. Por exemplo, 
na primeira vez que respondeu sobre sua viagem, mencionou o nome do navio.

Precisamos trocar a fita e recomeçar a resposta. Durante a segunda gravação, poucos minutos após a primeira, ela disse que se esquecera do nome do navio.

Outro esquecimento aconteceu quando tentou declamar a poesia de que gosta, de Frederico Garcia Lorca, "A casada infiel”. Lembrou-se apenas do início, fez um esforço de memória diante da câmera, mas não conseguiu declamar.

Bosi (2003) menciona que fazem parte da memória os esquecimentos, as omissões e os trechos desfiados de narrativa. Segundo ela, no trabalho da memória, são esses componentes que atestam a autenticidade das narrativas.

\begin{abstract}
Mas, se quisermos nos aproximar da esfera que resiste ao formato social, registremos atentos as hesitações e silêncios do narrador. Os lapsos e incertezas das testemunhas são o selo da autenticidade. Narrativas seguras e unilineares correm sempre o perigo de deslizar para o estereótipo. (BOSI, 2003, p. 63).
\end{abstract}

Nas gravações das quatro entrevistas, pude presenciar as situações descritas por Bosi. E os esquecimentos, lapsos e silêncios foram elementos constituintes da construção dos personagens e da narrativa do documentário no estágio da finalização.

Bosi (1994) menciona que há dois tipos de memória: a memória-hábito, adquirida pelo esforço da atenção e pela repetição de gestos ou palavras e que se dá pelas exigências da socialização, e a a memória pura, que, segundo Bosi, opera no sonho e na poesia, está situada no reino privilegiado do espírito livre.

Minha intenção foi, por meio das entrevistas, acessar os dois tipos de memória. Mas, particularmente, procurei perguntar e buscar maneiras de acessar a memória pura de cada entrevistado. A todos perguntei quais eram seus sonhos e se os haviam realizado. As pessoas que têm acesso mais direto a esse tipo de memória narraram situações únicas. 
Minha intenção foi acessar também as sensações e sentidos dos entrevistados, ao perguntar a eles quais cheiros lembravam a Espanha. Entretanto, nem todos conseguiram ter esse acesso. Uma única entrevistada respondeu, poeticamente, sobre quais são as cores que simbolizam a Espanha para ela.

Em última análise, estava em busca de acessar a cultura subjetiva dos entrevistados. Bosi (2003), citando o conceito formulado por Simmel, delineou que a cultura subjetiva situa-se na sombra quase inalcançada pelo historiador; reino dos sonhos, afetos, imagens, impressões, intuições.

Consegui, em boa medida, gravar momentos das narrativas em que os entrevistados expressam suas memórias puras e suas culturas subjetivas. Como exemplo, há a descrição das emoções positivas que uma das entrevistadas sentiu ao avistar na Baía de Guanabara. Ao descrever a paisagem do lugar, por meio de suas memórias, sua habilidade narrativa se compara ao trabalho de um pintor:

Fita Espanhóis no 12
16’34" (Margarita) - La impresión que Brasil, el primer momento, tienes dos
impresiones que yo "tive" muy fuertes. Una es cuando el navío llega a Baía
de Guanabara. Aquello es la cosa más maravillosa que una persona puede
sentir. Es la emoción más fuerte que se puede sentir en la vida, ver la Baía
de Guanabara, las luces, las sirenas, "as" estrellas, el mar "e você" llegando
a una tierra tan desconocida. Entonces la emoción "é" muy fuerte, y... la...
y... la entrada del navío... "no" Rio de Janeiro "é" muito bonita. "Mesmo que
você esteja...de baixo astral, "consigue" levantar ele". (Um documentário de
afeto: espanhóis na cidade de São Paulo. Direção: Isabel Blanco. Ano
produção 2009).

Por este esforço de memória, percebe-se que o trabalho da narradora, ao narrar suas emoções na chegada ao Brasil, evoca, dá voz, faz falar, diz de novo o conteúdo de suas vivências. Segundo Bosi (2003), enquanto o narrador evoca, está vivendo, atualmente e com uma intensidade nova, a sua experiência. 
Ao compartilhar com os entrevistados suas narrativas, na relação ouvinte e narrador (documentarista e entrevistado) nasce, segundo Bosi (2003), uma relação baseada no interesse comum em conservar o narrado que deve ser reproduzido.

Bosi (2003) reflete acerca da relação construída (encontro) entre o narrador e o ouvinte (documentarista e entrevistado).

Narrador e ouvinte irão participar de uma aventura comum e provarão, no final, um sentimento de gratidão pelo que ocorreu: o ouvinte, pelo que aprendeu: o narrador, pelo justo orgulho de ter um passado tão digno de rememorar quanto o das pessoas ditas importantes. Ambos sairão transformados pela convivência, dotada de uma qualidade única de atenção. (BOSI, 2003, p. 61).

A experiência do encontro e do embate com os entrevistados possibilitou-me os aprendizados construídos, por meio das narrativas acessadas pelas memórias de cada um.

Lidar com a memória é tarefa que exige cuidado e atenção, por sua característica fluida, pois segundo Bosi (2003), a memória oral é fecunda quando exerce a função de intermediário cultural entre gerações. 


\section{CAPÍTULO 2}

\section{DUPLA PERSONALIDADE DO DOCUMENTÁRIO: A DO REALIZADOR E A DO \\ TEMA}

\subsection{Abordagem pessoal}

A questão da alteridade vem me instigando há vários anos, mas, na mesma medida em que ela me instigava, também me desviava desse tema, pois muitos aspectos me assustavam ou me magoavam, por envolverem várias questões psicológicas a serem resolvidas.

Os questionamentos vieram à tona nas conversas de orientação com a Profa. Marília Franco. No início do processo de pesquisa bibliográfica sobre a imigração espanhola, para elaboração do projeto de pesquisa, ela questionou por que eu não falava espanhol e por que negava meu lado espanhol. Disse, ainda, que, ao mesmo tempo em que eu negava esse lado, meu filho (à época - em 2005 - com 16 anos) era um típico espanhol. Todas essas questões eram inconscientes para mim. A partir daquele momento, comecei a compartilhar dessas provocações existenciais.

Também percebi que pesquisar sobre esse tema significaria fazer uma terapia sem terapeuta, pois não teria condições financeiras de arcar com os custos de tal acompanhamento. Mas devo admitir que, se não fosse a confiança na Profa. Marília, não teria optado por esse tema. A partir daquele momento, não sabia por onde iria meu processo de "caminhante". Mas estava tranquila e segura para enfrentar tais desafios, pois me sentia acompanhada por ela. 
Com essa perspectiva de curiosidade, empenhei-me para descobrir esses meandros existenciais, na intenção de elaborá-los psicologicamente. A esse fator, uniu-se a busca de mim mesma, inclusive de minha identidade cultural.

Em 2005, iniciei a pesquisa bibliográfica sobre a imigração espanhola no Brasil. Isso me possibilitou o acesso direto a muitos aspectos de minha história, de minhas raízes. Desde então, alguns momentos têm sido dolorosos, "densos", "pesados", fruto das minhas idiossincrasias escorpianas, pois vivencio tudo muito profunda, visceral, "hispânica", "latina" e "brasileiramente"! Essa natureza não me dá muitas folgas. Mas, por outro lado, aprendo a ponderar e a não sofrer nem me preocupar tanto com questões que, às vezes, não têm respostas imediatas. Em suma: tenho vivenciado uma revolução interior que demanda muito trabalho, empenho e coragem.

Desde o princípio, esta trajetória tem sido recompensadora e reconciliadora, com a cultura espanhola, comigo mesma e com meu pai. Comecei a estudar o idioma espanhol no ano de 2006, pois até então somente ouvia meu pai falar espanhol; eu nunca havia escrito ou falado idioma ancestral. Descobri que meu ponto de vista sobre esse assunto era o ponto de vista de meu pai.

Minha irmã e eu crescemos ouvindo de nosso pai que éramos brasileiras, não espanholas. Esse ponto de vista significou um rechaço dele a mim como espanhola e, por consequência, de mim mesma para o acesso à cultura espanhola. Por isso o bloqueio. Hoje, temos o direito à nacionalidade espanhola, garantida por lei.

Depois de tantas reflexões sobre as identidades culturais, sinto que tenho muitas características da herança espanhola, como também da distante herança italiana. Hoje me sinto parte brasileira, parte latino-americana e parte espanhola. Segundo Stuart Hall (2000, p. 46), o indivíduo contemporâneo foi descentrado e 
convive com identidades abertas, contraditórias, inacabadas e fragmentadas. Como sou aficionada pelo conhecimento e, particularmente, pelo aprendizado e estudo de idiomas, fui descobrindo a língua espanhola e me defrontando com o conhecimento do idioma de forma mais sistemática, por meio de um curso de extensão. Desde o início, fui constatando que a convivência com meu pai possibilitou a construção de um conhecimento significativo do idioma espanhol, que eu compreendia e lia bem, mas não falava nem escrevia.

A descoberta do léxico, da gramática e da fonética, juntamente com as particularidades do idioma e suas distinções do português têm me surpreendido a cada dia e me ajudado a me inserir na cultura espanhola.

Aliada à abordagem pessoal, vivenciada pelo contato direto com a cultura espanhola, minha trajetória profissional colaborou favoravelmente para processo de produção das entrevistas em formato de documentário, pois os 16 anos de experiência como produtora audiovisual me possibilitaram realizar o trabalho prático dessa pesquisa. Isso significa conceber a realização a partir da minha experiência profissional: a produção. Em outras palavras, parto desse lugar de conhecimento.

Enquanto estava sem parcerias ou equipe para a produção das entrevistas, não conseguia vislumbrar a possibilidade da produção, já que minha filosofia profissional construída pressupõe o trabalho audiovisual como uma prática coletiva. Costumo trabalhar com esse fundamento no ambiente profissional em todos os momentos do processo de realização: criação e produção. Vivenciar essa etapa inicial do mestrado foi bem difícil, pois é o paradoxo do ambiente de produção: a solidão como companheira. 


\subsection{A viabilização da produção}

Após lidar com o tema de forma solitária, em agosto de 2008 foi acertada uma parceria com a produtora audiovisual Videosfera Multimídia Ltda., cujos sócios são integrantes do grupo de pesquisa Aruanda lab.doc. A Videosfera é uma produtora independente, que realiza documentários, vídeos de não-ficção (institucionais, de treinamento etc.) e curtas de ficção. Seus sócios são Paulo César (PC) Toledo, cinegrafista, diretor de fotografia, editor e diretor, e Fabiana Sanches, produtora executiva.

A Videosfera dispunha dos recursos tecnológicos, necessários para captação e edição das entrevistas, e dos recursos humanos, mais importantes que os recursos de infraestrutura. Além da experiência adquirida ao longo das trajetórias profissionais de seus sócios, havia o fator da sensibilidade e solidariedade humanas existentes, imprescindíveis para a realização do projeto. Desde o início do processo de trabalho, percebi o empenho e a participação deles na concepção das gravações das entrevistas com os imigrantes espanhóis.

Minha ideia inicial era produzirmos um número de imigrantes espanhóis predefinidos por nós e gravarmos em suas residências. A opção por esse ambiente deveu-se ao fato de querer estabelecer relações de maior intimidade com os entrevistados.

Em nossa primeira reunião, afirmei que tinha delineado apenas algumas diretrizes sobre a direção. Disse a PC e Fabiana que precisaria de sua colaboração para essa concepção, uma vez que seria minha primeira iniciativa na direção. Comentei que gostaria de construir, como fruto do trabalho coletivo, a proposta estética das gravações e posterior edição. 
As ideias sugeridas por eles foram de grande valor e complementaridade das ideias iniciais que havia apresentado. PC sugeriu que produzíssemos alguns pais e filhos sendo entrevistados ao mesmo tempo. Assim, teríamos pontos de vista de duas gerações diferentes. Também sugeriu que pudéssemos tratar alguns assuntos com humor. Essas ideias foram acolhidas pela equipe.

Fabiana, neta de espanhóis, com sua liberdade de criação e conhecedora da cultura espanhola pela apreciação das comidas típicas, sugeriu que, na gravação de algumas entrevistas, oferecêssemos petiscos típicos espanhóis, a fim de começarmos em clima descontraído e intimista. Surpreendeu-me sua liberdade de criação, pois, sendo eu uma produtora de televisão, padronizada no sistema de produção em série, jamais me ocorreria tal ideia. Comecei a perceber os aspectos positivos da produção independente.

Nessa reunião, começamos a definir a linguagem das gravações: haveria uma câmera principal (HD), fixa no tripé para gravar as entrevistas, e uma câmera móvel (Mini-DV), que captaria a entrevista como câmera adicional (contra-plano) e também as conversas mais informais de cada entrevistado na preparação do personagem antes da entrevista e em algumas situações de suas casas. O áudio seria captado por um microfone direcional, durante as entrevistas, e por um microfone acoplado à câmera móvel para as cenas gravadas com ela.

Também comentei com eles a ideia de produzirmos, com os entrevistados, seus objetos biográficos, que são objetos que acompanham as pessoas ao longo de suas vidas e que têm valor afetivo e espiritual (BOSI, 2003, p. 25). Por meio deles, poderíamos iniciar as entrevistas de forma mais intimista e mais humanizada, se fosse possível. 
Propus que tentássemos estabelecer com os entrevistados uma relação de empatia, de alguém que tem testemunhado a trajetória de um imigrante, por ter ouvido as histórias de meu pai. Nessa aproximação, desde a pesquisa de personagens até as datas de gravações propus uma aproximação ao método de trabalho dos antropólogos/realizadores. Sua postura profissional, que tem como objetivo o estudo da cultura de grupos étnicos, tem como pressuposto básico o conhecimento da cultura dos grupos pesquisados para, depois de certo tempo de convivência, gravar os documentários.

Após a primeira reunião com PC Toledo e Fabiana Sanches, outro profissional integrou-se à equipe: Fábio Cintra, diretor musical. Sua chegada aconteceu durante a leitura do projeto do mestrado, à ocasião do meu ingresso, no ano de 2007. A escolha de Fábio Cintra deu-se por sua formação e experiência profissional em composição musical e pela proposta para concepção da trilha sonora: de não trabalhar apenas com os gêneros musicais espanhóis mais conhecidos, como o flamenco, por exemplo, mas também com outros desconhecidos do grande público brasileiro, destacando os gêneros musicais regionais daquele país. Gostei dessa concepção, pois concordava com a opção. Após definida essa primeira diretriz, ele foi integrado à equipe.

O último - mas não menos importante - profissional integrado à equipe foi Vanderley Mastropaulo. Ele exerceu as funções de operador da câmera móvel, pesquisador, assistente de produção e edição. Vanderley é mestre pelo PROLAMUSP (Programa da América Latina), integrante e pesquisador do Aruanda lab.doc.

Os locais (locações) escolhidos para as gravações foram as residências dos entrevistados, pois entendo que esse ambiente privado seja o espaço onde a 
intimidade se configure como atmosfera apropriada para a evocação de suas lembranças e memórias das narrativas.

A entrevista teve a intenção de revelar os dois tipos de memórias definidas por Bosi (1994): memória-hábito e memória-sonho dos entrevistados.

O conceito de objeto biográfico, conforme postula Bosi (2003), foi transposto para o audiovisual por meio da linguagem da câmera móvel e eventualmente captado com a câmera fixa.

Em última instância, a intenção foi o revelar das alegrias, das tristezas, dos sonhos, dos traumas, das imaginações dos entrevistados diante de nós (equipe de gravação e câmeras), o que se constituiu na essência das narrativas e na proposta da direção.

\subsection{Documentário: assistir, discutir, estudar, ensinar e, acima de tudo, aprender}

A convivência com documentaristas e pesquisadores do audiovisual de nãoficção tem acontecido, principalmente, graças ao grupo de pesquisas Aruanda lab.doc. Sou integrante do laboratório desde o ano de 2005.

Nas reuniões realizadas aos sábados, além de discutir e analisar aspectos teóricos da linguagem audiovisual da não-ficção, em conexão com a sua dimensão de informação, de entretenimento e de experiência estética, o grupo recebe profissionais e pesquisadores de áreas transversais - história oral, jornalismo, legislação, preservação e restauro, constituição de acervo, tecnologia etc. - e realizadores. 
O grupo tem como visibilidade principal o sítio Mnemocine (www.mnemocine.com.br/aruanda), desenvolvido como parte da dissertação de mestrado de Flávio de Souza Brito, apresentada e defendida na ECA-USP em agosto de 2001. Todo o sítio foi criado e desenvolvido como um instrumento de apoio e interação para o ensino de audiovisual, com seções sobre audiovisual e educação, cursos, oficinas, cineclubes etc.

Desde a sua criação, a equipe do Aruanda lab.doc. também constituiu um acervo preliminar de imagens (em vídeo digital), com entrevistas e depoimentos realizados (alguns deles transcritos e publicados no sítio), bem como documentários realizados por membros do grupo, finalizados ou apenas captados.

Além disso, os líderes e outros pesquisadores do grupo têm atuação permanente na área de ensino e pesquisa de audiovisual, com ênfase em produção de não-ficção, incluindo, nessas atividades, os segmentos de ensino de primeiro, segundo e terceiro graus.

O grupo analisa os métodos de realização dos documentários partindo da hipótese de que, na medida em que os audiovisuais de não-ficção têm por condição fundante o compromisso com o real, não há uma metodologia unificadora dos procedimentos de produção.

Como hipótese de pesquisa, acredito que, na realização documental, os métodos se impõem pelo embate entre o assunto, o olhar do realizador e as condições de produção e pela busca de um equilíbrio entre os conceitos e métodos preestabelecidos e aqueles estruturados historicamente e, diretamente, na prática. Como proposta de análise, identifico como condições de produção aquelas que dizem respeito às etapas de criação e gerenciamento do projeto. 
No âmbito da criação são analisados neste capítulo: a abordagem pessoal, a construção do conhecimento acerca do objeto de estudo e o vínculo ideológico com o documentário. O processo de aproximação com os entrevistados será analisado no capítulo três.

Dentre as condições de produção relativas ao gerenciamento do projeto, que serão contempladas no capítulo quatro, estão: a demanda, o financiamento e a formação da equipe.

Os procedimentos de produção, que serão analisados no capítulo quatro, compreendem: pesquisas preliminares, roteiro de gravações, gravação das entrevistas, edição e montagem, inserção social e procedimentos de produção para finalização do documentário.

Meu aprendizado adquiriu maior aprofundamento na cultura documentarista no ano de 2008, principalmente com relação às questões de ordem da produção do documentário. O Aruanda lab.doc, sob a coordenação da Profa. Dra. Marília Franco, iniciou uma nova atividade: concebeu e ministrou dois cursos de documentário, que envolviam teoria e prática. O primeiro aconteceu no primeiro semestre, em parceria com o SESC Vila Mariana. Coube a Ana Cristina Venancio da Silva e a mim a coordenação do curso. Essa experiência foi inédita e importante, na medida em que todos os integrantes do Aruanda participaram do planejamento do curso e, posteriormente, vivenciamos a experiência de ministrar as aulas em grupo. Partimos de um novo paradigma conceitual, fruto da experiência da trajetória profissional da Profa. Marília Franco.

O enfoque do curso eram as competências e habilidades necessárias ao processo da produção audiovisual: expressão visual (fotografia e direção de arte), sonora (projeto de som), articulatória (roteiro e edição) e habilidade gerencial 
(produção e direção). Cada dupla de professores responsáveis pela aula concebia o assunto à luz da(s) habilidade(s) envolvida(s). Assisti a todas as aulas. Ao final do curso, previa-se a gravação e edição de um exercício com duração de cinco minutos. Foi interessante aprender com as aulas, com a prática do exercício, quando os alunos narravam suas experiências do embate com o mundo histórico.

No contexto desse curso, consegui resolver várias dúvidas e questões, entre elas: se na produção do documentário não há roteiro fixo desde a gravação, como ele, de roteiro de gravação, transforma-se em roteiro de edição?

O segundo curso transcorreu ao longo do segundo semestre do ano de 2008. Foi realizado em parceria com a São Paulo Film Commission e a USP - Ribeirão Preto, como curso de extensão universitária, com carga horária maior do que o anterior. Isso nos possibilitou um aprofundamento teórico.

Os perfis dos alunos inscritos eram diferenciados. Em sua maioria, eram profissionais da área audiovisual da região ribeirão-pretana interessados em apreender novos repertórios e novos métodos de produção e concepção, uma vez que suas experiências profissionais estão voltadas para atender ao mercado audiovisual regional: telejornalismo, publicidade e institucionais. Nesse curso, percebemos o processo de aprendizagem e construção de conhecimento dos alunos. Após o término da aula de produção e direção (Tatiana Polastri, produtora de documentários da Varal Filmes, e eu ministramos a aula), notamos a transformação dos alunos quando descobriram os fundamentos da produção. Ao sairmos da aula, eles estavam raciocinando como produtores. Suas preocupações eram com orçamentos a serem elaborados e seguidos, cronogramas a serem cumpridos, compromissos a serem agendados, enfim, estavam prontos para produzirem seus exercícios. Foi uma experiência singular. 
Ao longo das discussões desse curso, também aprendi acerca das nuances da produção do documentário. Percebi que a hipótese do Aruanda estava se comprovando. Cada documentário e seu tema impõem desafios particulares ao documentarista. Porque os temas eram diferenciados entre os grupos, cada grupo formulou seu tema de interesse sobre questões da região ribeirão-pretana. Ao longo do processo de produção, constatamos que as necessidades da produção eram pertinentes e específicas de cada tema.

\subsection{Vínculo ideológico com o documentário}

Refletindo sobre a experiência no Aruanda lab.doc, percebo que essa participação sintetizou e consolidou meu gosto e as identificações (políticoideológicas, de conteúdo e formatos) com o documentário.

Passei minha vida ouvindo as histórias de meu pai, que cresceu na Espanha franquista, vivenciou e desenvolveu análise crítica sobre o totalitarismo daquele regime. Passados os anos, percebeu que o franquismo não iria terminar tão cedo. Então, resolveu imigrar em 1959.

Como diria meu pai, "mamei" esses conhecimentos sobre a vida, sobre a história, por meio de suas narrativas. E, como ser humano histórico que ele me ensinou a ser, jamais poderia olhar esse mesmo mundo histórico deixá-lo passar despercebido por mim!

Quando me casei com Vando (José Vando Pires Arruda), paraibano e sertanejo, em 1986, decidimos morar em João Pessoa, Paraíba. Estávamos em busca de melhor qualidade de vida, onde pudéssemos associar o trabalho e 0 
estudo gratuito em uma universidade pública - a UFPB (Universidade Federal da Paraíba).

Em João Pessoa, tive uma experiência de vida social significativa, ao conhecer de perto a miséria de grande parte da população. Foi somente viajando pela Paraíba (desde a zona litorânea até o sertão) que tive a oportunidade de observar que parte do Brasil era muito diferente do que eu conhecia até então: a cidade de São Paulo e algumas cidades litorâneas do estado.

Estudava jornalismo na UFPB, conforme mencionado anteriormente, e trabalhava lecionando inglês na Cultura Inglesa. Paralelamente, trabalhava como voluntária no CDDH - Centro de Defesa dos Direitos Humanos - de João Pessoa, coordenado por Wanderley Caixe, ex-militante estudantil e advogado. Colaborava com o trabalho de gênero e de educação popular de mulheres, coordenado por Ayala Rocha, pedagoga e ex- militante estudantil.

Esse trabalho consistia em encontros semestrais entre as profissionais do Centro de Defesa e as mulheres agricultoras (posseiras) de pequenas propriedades rurais. Elas relatavam as situações de conflito que vivenciavam cotidianamente, que se traduziam em ameaças de grileiros e de grandes fazendeiros para que deixassem suas terras. Muitas vezes, tinham suas vidas ameaçadas por eles.

Cabia à coordenadora, Ayala, a orientação das agricultoras, do ponto de vista jurídico e educacional, a fim de que tivessem mais informação e ferramentas para lidar com tais situações.

Além dessa atividade, era editada uma revista feminina intitulada "Vamos!". No Centro de Defesa, havia um grande acervo de publicações, provenientes de diferentes países do mundo, sobre o tema dos direitos humanos. Essas leituras faziam que eu não me sentisse tão isolada do mundo, pelo menos do fluxo de 
informações do eixo Rio-São Paulo. Há de se lembrar, nos anos 1990, não havia computadores nem internet na Paraíba.

Pode-se considerar aquele trabalho político-social o correspondente contemporâneo das Ligas Camponesas. Dona Elisabeth Teixeira, esposa de João Pedro Teixeira e protagonista do documentário "Cabra Marcado Pra Morrer" (Direção: Eduardo Coutinho, 1985), era funcionária do Centro e também participava das reuniões com as mulheres, orientando sobre os procedimentos a partir de sua atuação política.

Depois da imersão nesse contexto cultural, e com a participação no Aruanda lab.doc, concebi este projeto de pesquisa, que tem como objeto de estudo o documentário.

O documentário, como produto audiovisual de não-ficção e que tem como princípio fundante o compromisso com o mundo histórico, demonstrou-se o formado com o qual eu mais me identificava, por meio da expressão artística audiovisual, para o estudo e pesquisa. Ele se constitui na forma pela qual sintetizo e expresso minhas experiências de vida, pessoais ou profissionais.

\subsection{Desafios a serem enfrentados}

Os desafios e dificuldades são de natureza acadêmica e prática, na produção do exercício como produção independente.

No aspecto acadêmico, pode-se mencionar como desafio e aprendizado todo o conhecimento que venho construindo para a pesquisa acadêmica: sistematização das informações, fichamentos, elaboração do texto acadêmico e articulação da 
teoria com a prática do exercício, juntamente com as práticas preestabelecidas da experiência profissional, que se consolidou na área de produção.

Portanto, este é o primeiro trabalho em que tenho de assumir a autoria, a direção. Minha atuação profissional constitui-se em execução de projetos audiovisuais para a televisão que já têm formatos predefinidos, linha de direção e temas pré-escolhidos. Ou seja, trabalha-se com projetos sob encomenda, na maioria das vezes.

Na direção das entrevistas, tive o apoio do PC Toledo. Fiz essa proposta a ele, pois sua experiência na concepção das gravações, direção e edição seria fundamental à realização, uma vez que eu não tinha experiência na atuação como diretora.

Desde as primeiras reuniões com a equipe, percebi meus condicionamentos de produtora de televisão: a produção em série. Nesse tipo de produção, estamos limitados à realização dos programas em um tempo mínimo de trabalho, geralmente uma semana para produção de um programa. Isso nos impõe o ritmo de criação e produção.

Quando comecei a trabalhar com a Fabiana, produtora executiva da equipe, percebi sua liberdade para criar e produzir quando ela sugeriu que, em algumas entrevistas, preparássemos alguns petiscos espanhóis para servir aos entrevistados e, assim, criar um ambiente mais descontraído. Consegui vislumbrar, então, o que significa a produção independente. Certamente, ela assume outro atributo na atuação profissional, pois todos, neste caso, assumem o trabalho como sendo de sua autoria. O compromisso e empenho são diferentes. Por isso me pareceu enriquecedora essa interação profissional: uma troca de experiências. 
Por outro lado, muito do que aprendi na trajetória profissional foi útil no sentido de estruturar a produção: organizar os roteiros de gravação, a pré-produção das entrevistas, a decupagem e transcrição das fitas e a posterior edição.

Esses são procedimentos que fazem parte da minha formação profissional. Imagino que ao longo do processo esses procedimentos preestabelecidos foram ajustados às necessidades específicas do projeto e do tema e também adaptados aos procedimentos utilizados pela equipe de produção.

\subsection{Da Espanha e dos espanhóis}

\subsubsection{A maneira rude do ibérico}

Quando se trata de alguns aspectos característicos da personalidade do espanhol, há que se considerar também tais características comuns aos portugueses, porque ambos os povos habitam uma região (a Península Ibérica) que apresenta similaridades históricas em vários aspectos (invasões e lutas de monarcas pela supremacia política) e alguns aspectos socioeconômicos afins. Pode-se considerar, em boa medida, que o povo ibérico tem como traço marcante a rudeza em sua maneira de ser. É preciso levar em consideração que esse "olhar" se constitui a partir do ponto de vista de pessoas não-ibéricas, como nós, brasileiros. Ou seja, esse olhar se elabora a partir da alteridade. Provavelmente, entre os ibéricos, essa rudeza não seja um traço de personalidade que os incomode.

No que diz respeito, especificamente, ao espanhol, ele é visto internacionalmente como uma pessoa de caráter bronco, de pavio curto e facilmente irritável, segundo Buades (2006, p. 13). 
Levando-se em consideração as raízes históricas da Espanha, ainda segundo Buades (2006), desde a Idade Média, os espanhóis foram criados no culto à intolerância e na proteção da honra a qualquer custo. Essa proteção da honra não se efetuava por meio da discussão e do diálogo, mas sim pela defesa das opiniões e ideias advindas das entranhas. É uma questão visceral, de ordem passionalemocional, mais do que racional.

Mais de três séculos de autoritarismo imperial e de perseguição inquisitorial modelaram o caráter coletivo dos espanhóis. Esse legado imperial e católico condicionou a história contemporânea do país. Portanto, nem os ventos contemporâneos da globalização nem a inserção do país na Comunidade Europeia se constituíram em experiências significativas para amenização da rudeza como traço da personalidade desse povo.

Além de a Espanha ter vivenciado longos períodos de conflitos e guerras, há o aspecto de que a cultura espanhola é, segundo Buades (2006), a cultura da dor e do sofrimento, presentes nas suas variadas manifestações, tanto eruditas como populares.

O sangue, a morte, o padecimento, o tormento ou o vazio existencial têm sido objetos de reflexão coletiva, de forma quase inconsciente às vezes. Esses temas têm inspirado letras de canções, obras literárias, peças teatrais, monumentos arquitetônicos, pinturas, esculturas e filmes. Até a chamada "festa nacional" é um desafio à morte, para a qual o sangue do touro é derramado. (BUADES, 2006, p. 16).

Considerando-se esses componentes culturais (a dor e o sofrimento), pode-se compreender a maneira pela qual o espanhol é visto como indivíduo tragicômico, porque alia sua forma dramática a um senso de humor muito particular, muitas 
vezes, ácido e de cachondeo (de tirar o pelo, como dizemos em português). E essa característica é tão marcante, que se faz presente nas narrativas das histórias de vida dos entrevistados para produção das gravações.

\subsubsection{A Espanha revisitada}

A percepção mais apurada e a interação com os espanhóis, pude elaborar em uma viagem de uma semana à Espanha (Valência), em novembro de 2008, para a XI Conferência de Centros Valencianos no Exterior.

Quando somos atendidos em restaurantes e cafeterias notamos essa maneira de ser do espanhol. Afinal, os profissionais que trabalham nesses estabelecimentos lidam com clientes da Espanha, da Europa e do mundo inteiro, uma vez que Valência é o terceiro maior destino turístico do país. Supunha que teriam um tratamento mais gentil e amável para a clientela.

Ao adentrarmos os estabelecimentos comerciais, somos abordados e exigidos que tenhamos nossos pedidos feitos o mais brevemente possível. Caso não correspondamos a essa expectativa, a esse "roteiro", já sentimos a impaciência e a rudeza no tratamento dos garçons e garçonetes: "Que quieren ustedes? Los bocadillos que existen son estes que están expuestos! Basta escojerlos!"

Percebe-se que é uma cultura em que não há espaço para as gentilezas nem para as delicadezas. Essas características, parece-me, são vistas por eles como traços de fraqueza.

A estadia de uma semana na Espanha propiciou-me o contato com a população, com a Valência contemporânea, ou seja, uma amostragem da Espanha globalizada. 
No centro da cidade, as pessoas andam apressadas, sem olharem umas para as outras. Ritmo típico de uma grande cidade urbana. Aquela ideia que eu fazia, de cidade praiana, balneária, foi dissipada pelo contato com esse ambiente próprio das grandes cidades contemporâneas.

Esse contexto em muito diferia do que eu havia concebido dentro de mim durante toda a minha vida, fruto dos relatos de meu pai, de uma Espanha antiga, a Espanha de suas memórias e lembranças nostálgicas. A Espanha que existe dentro dele!

Outra imagem, mais difusa, era a que eu tinha da primeira viagem que fiz para lá, aos sete anos de idade. Minhas lembranças eram muito vagas, flashes da Espanha daquele período. Agora, adulta, pude ter uma percepção mais crítica.

Estando lá e sentindo esse ritmo do ambiente, as pessoas nas ruas e nos parques, vivenciando seu cotidiano, pude estabelecer minha relação com a Espanha contemporânea, em que não há muito espaço para devaneios e relações idílicas, somente o vivenciar do cotidiano desta Espanha europeizada e globalizada.

Essa percepção atualizou, re-elaborou e reavivou meus sentidos acerca da cultura espanhola e dos espanhóis. Mas, ao mesmo tempo em que senti esse estranhamento e distanciamento, também vivenciei momentos de identificação, nas conversas com os espanhóis de centros valencianos da América Latina e da Espanha. Nesses momentos, sentia-me "em casa" quando ouvia sobre a Espanha ou sobre os países de destino dos imigrantes espanhóis, ou até mesmo em assuntos triviais sobre aspectos da culinária brasileira, como a feijoada.

Duas espanholas, madrilenas, perguntaram-me o que é feijoada e quais são os ingredientes desse prato. Instintivamente respondi que é uma receita parecida com o cozido madrileño, apenas diferente nos ingredientes de carnes e embutidos. 
Elas entenderam perfeitamente o que poderia ser e espantaram-se pela minha naturalidade em decodificar e transitar pelas duas culturas. Foi uma constatação muito interessante para mim também. Nesse momento compartilhado, senti-me espanhola e conhecedora de aspectos da cultura madrilena, devido à convivência com meu pai.

Depois de passar a vida toda ouvindo meu pai falar espanhol, mas sem falar o idioma, resolvi aprendê-lo em um curso. Estudei por um ano e meio e esse período foi o início do processo de estabelecimento de uma nova relação com a cultura espanhola.

Por meio do idioma e da convivência com essa cultura durante toda a minha vida, e por ser (parcialmente) espanhola, consegui me integrar a algumas comunidades de espanhóis existentes na cidade de São Paulo. Mas há um componente importante: minha identidade brasileira. Por mais que conheça e compreenda os códigos da cultura espanhola, meu lugar de observação se origina, primordialmente, da condição de ser brasileira e latino-americana. Portanto, um lugar de alteridade e, ao mesmo tempo, de identificação. 


\section{CAPÍTULO 3}

\section{ENTREVISTADOS E DIRETORA - A APROXIMAÇÃO}

Desde o ano de 2005, tenho estabelecido contato com a comunidade espanhola por meio da participação em duas grandes convocatórias de espanhóis residentes em São Paulo. Essas convocatórias partiram do Escritório Laboral do Ministério de Trabalho e Imigração da Espanha e tinham como objetivo a explanação dos programas sociais do governo central aos espanhóis no exterior. $\mathrm{Na}$ ocasião, fui aos eventos com meu pai e meu filho, João Pedro. Percebia-se claramente o caráter político dos dois eventos, que receberam políticos espanhóis integrantes do Ministério do Trabalho e da Imigração. Estes fizeram seus pronunciamentos em tom entusiasmado de campanha política (eram datas próximas às eleições) a favor do PSOE (Partido Socialista Obrero Español), partido no poder central desde aquela época.

Naquele ano, tive pouco contato, além desses, com comunidades espanholas. Somente no momento de iniciar a pesquisa de personagens, em janeiro de 2007, é que voltei a me aproximar dos diretores de instituições, a fim de conhecer algumas comunidades espanholas.

De acordo com minha formação pessoal e educacional, sempre tive em mente que meu papel de pesquisadora e realizadora na relação a ser construída com os imigrantes não seria a do "intelectual" que faz sua pesquisa de campo, extrai o que necessita das pessoas e nunca mais retorna. Isso porque, pela convivência em família com espanhóis, sei que há uma grande desconfiança deles com relação a estranhos. Sempre ouvi meu pai dizer que muito mais valem as atitudes do que as palavras. Para o espanhol conhecer alguém, é preciso que essa pessoa demonstre 
quem ela é. Demonstração essa que tarda um tempo para estabelecer um vínculo e uma relação de amizade ou, caso contrário, caso a pessoa não se revele amiga, não será considerada uma integrante do grupo ou do círculo de amizades. Por outro lado, se a amizade se revela, é bem possível que a pessoa tenha um amigo por longos anos.

O tipo de aproximação com os imigrantes tinha de expressar o respeito a todos das comunidades para que, ao longo do tempo de convivência, eles não me vissem mais como uma estranha, mas como uma integrante do grupo. Ainda não me via nem me sentia espanhola. Nas primeiras vezes em que visitei a Sociedade Hispano-Brasileira de Socorros Mútuos - maior comunidade espanhola existente na cidade de São Paulo, situada na zona sul da cidade, bairro do Ipiranga - os olhares eram de estranheza e de questionamento sobre quem eu seria. Sempre estava acompanhada de alguém da comunidade para não me sentir "estranha no ninho".

Depois de algumas visitas àquela sociedade em ocasiões de festividades, resolvi marcar uma conversa com o diretor cultural na época, o Sr. Francisco Javier. Esse primeiro contato deu-se em janeiro de 2007. Quem me forneceu o número do telefone dele foi a chefa da Sección de Trabajo e Inmigración de São Paulo, órgão pertencente ao Ministério do Trabalho e Imigração espanhol, Ana Maria Serrano Oltra. Ela conhecia meu projeto porque havia encaminhado a solicitação de apoio econômico por meio do Programa de Proyectos de investigación, do Ministério do Trabalho e Imigração.

A primeira vez em que o projeto de realização do documentário foi apresentado, no ano de 2005, foi em nome de pessoa física; meses depois, veio a devolutiva: recusado. Após saber da negativa de apoio econômico por parte do governo espanhol, perguntei à Sra. Ana Maria quais eram os critérios de avaliação 
para que pudesse encaminhá-lo no ano seguinte. Ela aconselhou-me que contatasse uma comunidade, que apresentasse o projeto em nome da comunidade e que a solicitação fosse acompanhada de um orçamento parcial do custo da produção.

Por isso procurei o Sr. Francisco. Na reunião, falei do projeto e do que necessitava naquele momento: conhecer espanhóis idosos, que chegaram à cidade de São Paulo após os anos 1960 e que frequentavam as atividades da sociedade. Era a etapa da pesquisa de personagens. Ele foi direto: "O que vou ganhar se eu der uma lista de nomes de sócios espanhóis?" Fiquei chocada com a situação colocada daquela maneira.

Respondi a ele como seria o processo e o critério de seleção dos personagens, disse que poderia começar a frequentar alguma atividade deles e começar a conhecê-los por meio de conversas, para saber suas histórias de vidas e detectar suas formas de narrativas, e acrescentei que poderia entregar, ao final do processo, o DVD editado das entrevistas gravadas.

Senti que ele não se contentou muito. Ficou bastante desconfiado. Resolvi procurar outra comunidade para conhecer outro trabalho e diferentes pontos de vista.

Na mesma semana, telefonei para a presidente do Centré Valenciá La Senyera de São Paulo, Mari Carmen Acirón Rius. Tinha conseguido seu número de telefone também por intermédio da Sra. Ana Maria, que também nos apresentou no evento da vinda dos políticos espanhóis. Marcamos a primeira reunião na sede do Centro Valenciano, na zona sul de São Paulo, bairro da Vila Mariana.

O Centro Valenciano, à época, estava situado em uma casa antiga e de fácil acesso aos sócios, próximo à estação Santa Cruz do metrô, zona sul da cidade, Rua 
José de Magalhães, 168. Infelizmente, após um ano e meio a casa precisou ser entregue porque a verba de ajuda para manutenção do centro, vinda de Valência, não cobria os custos totais do aluguel.

Era uma casa decorada com vários símbolos espanhóis e valencianos: bandeiras, pôsteres de lugares turísticos, pequenos quadros de figuras típicas valencianas (camponeses vestidos a caráter), fotos de festas comemorativas realizadas pelo Centro etc. Na cozinha, havia um fogão industrial, uma geladeira, um freezer e uma mesa redonda com duas cadeiras. O armário embutido guardava uma infinidade de louças e vasilhas para os eventos festivos gastronômicos. Havia uma sala de estar, onde ficavam alguns livros sobre Valência; além da televisão e da mesa grande, havia carteiras para aulas e, como não poderia faltar, logo à porta, estava um manequim vestido com a roupa típica da fallera - segundo a tradição valenciana, a roupa da moça que representa sua comunidade na festa maior da cidade: as fallas (fogueiras de Valencia). Essa roupa pode ter diversas cores e caracteriza-se pelo grande número de enfeites e bordados.

O ambiente que dava à entrada principal da casa era uma conjugação de sala de estar e sala de aula. E finalmente, na frente da casa, próxima ao jardim, havia uma sala decorada com estilo de um escritório e biblioteca.

A casa do Centro Valenciano era um ambiente bem organizado e arrumado. Muito simples, mas aconchegante. Na primeira reunião com Mari Carmen, ela mostrou-me a casa e contou-me sobre as festas e eventos que faziam. ApresenteiIhe o projeto e sua reação foi de acolhimento e de grande consciência acerca da valorização de tal projeto como "documento" sobre a imigração espanhola em São Paulo. 
Mas o fator decisivo para o início dessa parceria deveu-se à sensibilidade, ao conhecimento e à compreensão para lidar com as culturas e à experiência em lidar com imigrantes espanhóis da presidente do Centro Valenciano. Carmen desenvolve seu trabalho com base na sua relação com as culturas valenciana e espanhola. Para ela, essa é a maneira pela qual mantém acesa a chama de suas raízes e tradições, frutos da convivência com seus pais. Além disso, ela possui grande habilidade de convivência e de trânsito intercultural. Casada com um português, viveu a maior parte de sua vida no Brasil, convivendo com seus pais, de ascendências espanhola e valenciana.

Carmen e eu construímos um vínculo de amizade tão profundo que, atualmente, considero-a minha "mãe espanhola". Esse sentimento foi fundamental e imprescindível para meu processo interior de reconciliação com a cultura espanhola e com meu lado espanhol.

A primeira sensação positiva foi o acolhimento ao projeto e a mim. Essa atitude me fazia sentir aceita como eu era, por completo. Até então, sentia-me rechaçada da cultura espanhola. Foi dessa maneira que ressoou a máxima de meu pai, pronunciada por ele durante toda a minha vida: você não é espanhola. Você é brasileira! Olhava-me por meio do olhar de meu pai; por isso negava minha identidade espanhola. Daí se criou o bloqueio com o idioma, mencionado anteriormente.

A oportunidade de realização deste projeto e a maneira como tenho me relacionado com ele tem sido o "passaporte" emocional e moral para a inserção e conquista da minha identidade espanhola e a conscientização no meu processo de amadurecimento psicológico, a individuação. 
Questão de honra, que envolveu e demandou muito estudo, trabalho, empenho, perseverança, coragem, reflexão interior e amor. Valores meus, apreendidos de meu pai, que tem atributos e grandes virtudes. Para mim não poderia ser de outra forma, oportunista ou utilitarista, por exemplo. Mais uma vez, o aprendizado e o valor do trabalho como princípio ético.

\subsection{A construção dos vínculos com a comunidade valenciana}

Durante o ano de 2007, participei de reuniões da diretoria e da organização de eventos. Também aproveitava os sábados para me reunir com Carmen. Na sede do Centro Valenciano, ela me mostrava livros, fotos, cartas e todo tipo de material que pudesse ser importante para o projeto. Além disso, conversávamos sobre muitos episódios de sua vida. Nesses momentos, compartilhava as alegrias e dores de sua história, ora na Espanha, ora no Brasil. Viagem imaginativa de vai e vem constante entre o presente e o passado; trabalho intenso de memória, aliado a seus dotes de hábil narradora; esse era o movimento constante de Carmen para me contar sua história de vida.

Àquela época, também fui conhecendo um número significativo de sócios. Contava-Ihes sobre o projeto e conversávamos muito sobre suas experiências como imigrantes no Brasil, suas vidas na Espanha e suas trajetórias. Naquela época, preocupava-me apenas em conhecer as pessoas e suas histórias. Por isso, avaliei que seria melhor não gravar ou anotar nada. Precisava conhecê-los e deixar que eles me conhecessem.

Colaborava com o Centro Valenciano na elaboração de trabalhos no computador, no planejamento e realização de eventos. Nessas horas, o aprendizado 
da produção é muito valioso! Carmen frequentou um curso de produção de eventos temáticos, o que a auxiliou nessas tarefas.

Também pude perceber como é a participação dos espanhóis e valencianos em comunidade e qual é a noção de comunidade que eles têm. São pouco integrativos. Apenas comparecem aos eventos como convidados.

Em agosto de 2008, organizamos uma paella a fim de arrecadar fundos para o Centro. Carmen convidou os sócios e pediu que eles levassem amigos; cerca de sessenta pessoas compareceram. Havia uma equipe de trabalho composta por seis mulheres. Coube a nós a organização de todo o evento: preparar a paella, colocar as mesas, servir comidas e bebidas. As pessoas chegavam e sentavam-se, aguardando que fossem servidas. Elas compareceram para comer paella mais barata do que em um restaurante, para "ajudar" na arrecadação de verba para o Centro e para conversar durante algumas horas; depois, foram embora. E, mais uma vez, coube à equipe de trabalho recolher tudo: cadeiras, mesas, lavar e guardar as louças, enfim, deixar a casa em ordem.

Pude perceber que os sócios não têm a noção de participação na comunidade como indivíduos ativos e co-responsáveis pela manutenção do Centro e da cultura valenciana. Ou seja, para eles, a atuação em uma comunidade como essa não é expressão de participação política, no sentido de trabalharem constantemente em regime de voluntariado em prol da comunidade valenciana e do centro valenciano, único no Brasil.

A atitude deles em comunidade significa reunir-se eventualmente para desfrutar momentos de lazer e prazer, como conversar e, acima de tudo, comer. 
Talvez seja essa reação de forte caráter individualista, existente na atitude do espanhol, que estabeleça a resistência ao convívio em comunidade, pois eles experimentam esse paradoxo:

Há um preço a pagar pelo privilégio de "viver em comunidade" - e ele é
pequeno e até invisível só enquanto a comunidade for um sonho. O preço é
pago em forma de liberdade, também chamada "autonomia", "direito à auto-
afirmação" e a "identidade". Qualquer que seja a escolha, ganha-se alguma
coisa e perde-se outra. Não ter comunidade significa não ter proteção:
alcançar a comunidade, se isto ocorrer, poderá em breve significar perder a
liberdade. A segurança e a liberdade são dois valores igualmente preciosos
e desejados que podem ser bem ou mal equilibrados, mas nunca
inteiramente ajustados e sem atrito. (BAUMAN, 2003, p. 10).

Somente quando comecei a conviver com os espanhóis é que compreendi esses aspectos de comportamento. Por que a atitude do espanhol, na sua inserção na sociedade de destino, a cidade de São Paulo, é tão diferente da atitude do italiano, por exemplo? A postura do espanhol na sociedade tem o significado de "não quero aparecer". Essa atitude estaria, inconscientemente, conectada à ideia de exílio político que muitos deles tiveram de adotar para sair de seu país de origem? Seria uma reação às perseguições incansáveis do regime franquista? Seriam sentimentos de um exílio emocional e econômico? Talvez estas perguntas suscitem hipóteses para algumas situações com as quais deparamos na pesquisa de personagens, mencionada neste capítulo.

\subsection{Momento significativo da participação política e aprendizagem do exercício} da cidadania

No mês de novembro de 2008, pude participar, como secretária-geral do Centro Valenciano de São Paulo, do II Encuentro de Centros Valencianos En El Exterior, organizado pela Generalitat Valenciana - Conselleria de Inmigración y Ciudadanía. Nesse encontro, primeiramente, foram discutidas as reivindicações dos 
Centros Valencianos da América Latina, no dia sete de novembro, e, no dia oito, os Centros Valencianos da Europa e da Espanha juntaram-se aos da América para complementarem as discussões.

As reivindicações dos Centros da América Latina foram referentes à ampliação de programas de ajuda para compra de sedes próprias, aumento no número de bolsas de estudo e solicitações concernentes às questões que subsidiem manifestações culturais valencianas nas comunidades. Já os centros localizados na Espanha e Europa têm essas conquistas garantidas. Suas reivindicações foram: maior participação política nas eleições, com direito a votação em cargos de deputados do governo central, e criação de um órgão institucional para articulação política dos centros com a Generalitat Valenciana e o governo central. Todas essas reivindicações estão fundamentadas no princípio de que os valencianos no exterior não têm os mesmos direitos que os valencianos residentes na cidade natal.

Após a participação no encontro, elaborei uma dimensão totalmente diferente da participação política em uma comunidade como a Valenciana. A distância geográfica e o isolamento sentidos no cotidiano, com relação às outras comunidades valencianas, foram minimizados no encontro. Conversando com os representantes dos centros da América, percebemos que os problemas e dificuldades são similares, devido aos contextos sócio-políticos dos países onde estão situados. Pudemos trocar experiências e receber sugestões para estratégias de trabalho. Conheci melhor os programas de ajuda aos centros e todas as políticas públicas da Generalitat Valenciana, destinados aos centros valencianos no exterior. No âmbito pessoal, o contato com os espanhóis dos centros da América Latina reacendeu a chama de minha identidade latino-americana. 
Após o evento, realizamos reuniões com os sócios colaboradores a fim de planejar as atividades do ano de 2008 para o Centro Valenciano La Senyera. Realizamos alguns eventos, mas as dificuldades eram grandes. A casa alugada, sede do Centro Valenciano, foi entregue; a verba arrecadada, juntamente com as ajudas da Generalitat, não era suficiente para pagar os aluguéis que estavam atrasados.

Desde o início de 2009, tive de me afastar das atividades de colaboração junto ao Centro para me dedicar mais ao exercício prático do mestrado e à escritura da dissertação.

Em abril de 2009, houve novas eleições para a diretoria do Centro. Há a necessidade de alternância das pessoas para "arejar" a gestão. Desde então, não sou mais a secretária-geral da instituição. Mas continuo a colaborar no que for necessário e possível.

Depois da convivência de dois anos na comunidade valenciana e em outras comunidades, como a sociedade hispano-brasileira, senti-me mais à vontade para iniciar a pesquisa de personagens para o exercício prático.

\subsection{Início do processo de pesquisa dos personagens}

Contei com o conhecimento e experiência de sete anos da presidente do Centro Valenciano para as primeiras indicações de nomes. No início de 2009, apresentei-Ihe os perfis das pessoas que poderiam se constituir em personagens: boas narradoras, que tivessem histórias de vida interessantes e que fossem oriundas de diferentes regiões da Espanha. Uma vez que o foco da entrevista seria a investigação das construções das identidades culturais, e considerando que a 
Espanha possui 17 províncias autônomas, esse critério de seleção seria de fundamental importância. Parti do pressuposto de que a Espanha é um país cuja diversidade cultural é traço marcante na constituição do Estado-nação.

Todas as iniciativas daqueles anos anteriores propiciaram a aproximação e a criação de laços de confiança e intimidade entre Carmen e eu, a ponto de apresentarmos o projeto parcial junto à Ofícia Laboral de São Paulo, em nome do Centro Valenciano, por duas vezes - 2007 e 2008. Dessa vez, o projeto previa gravações das entrevistas em áudio para a pesquisa de personagens do exercício prático. Seriam as pré-entrevistas. Os projetos de 2007 e 2008 foram aceitos pelo governo espanhol. Mais tarde, em reunião com os parceiros da produtora Videosfera, decidimos que as gravações poderiam ser em audiovisual em vez de serem somente em áudio.

Carmen elaborou uma lista de 39 pessoas. Conforme entrevistava informalmente as pessoas, constatei que a maioria delas era valenciana. Esse fator contradizia um dos critérios de seleção, que era a diversidade cultural. Portanto, fui diminuindo o número de pessoas. A segunda lista, surgida a partir da primeira, tinha 27 nomes. Continuei com as pré-entrevistas a fim de conhecer melhor as histórias de vida dos imigrantes para poder selecionar um número menor e começarmos a gravar as entrevistas em audiovisual. Chegamos a uma terceira lista, com 11 nomes.

Com esse universo, pude entrevistar os imigrantes e, a partir daí, selecionar algumas pessoas que atendessem aos perfis delineados. Nessa lista, finalmente foi possível escolher os quatro personagens que teriam suas entrevistas gravadas em audiovisual.

Além dos colaboradores e sócios do Centro Valenciano, entrevistei pessoas conhecidas, ligadas ou não às comunidades de espanhóis. 
Para as pré-entrevistas, elaborei um questionário ${ }^{7}$ que contemplava os períodos mais significativos das histórias de vida das pessoas. Esse questionário teve como fundamentação as perguntas das entrevistas realizadas por Freitas, em seu trabalho de História Oral realizado no Museu da Imigração, na cidade de São Paulo. (FREITAS, 2006, p. 26).

Os temas contemplados nas perguntas diziam respeito a: origem, festas e músicas, motivos da imigração, a viagem, da tradição aos novos costumes, construção das identidades culturais, estabelecimento de suas vidas no Brasil, seus sonhos, alegrias e tristezas.

Conceber as perguntas em formato de temas seria um recurso facilitador para o processo posterior à gravação: a edição. Quando as entrevistas estivessem gravadas, poderia agregar os temas comuns a todos os personagens, articulando-os com os temas novos que surgissem. Essa seria uma estratégia preliminar para se conceber o eixo narrativo da edição. Os temas poderiam se constituir nas sequências da edição.

O processo das pré-entrevistas foi fundamental, pois, com os questionários preenchidos, tínhamos as informações sistematizadas para poder escolher, uma vez mais, as entrevistas com as histórias de vida e narrativas mais significativas. $O$ procedimento de produção para se estabelecer um documento que registrasse as informações apreendidas nas pré-entrevistas foi sugerido pelo diretor documentarista Camilo Tavares. Camilo é integrante do Aruanda lab.doc. Certa vez, ele exibiu seu documentário intitulado "Cosmópolis" para o grupo, a fim de discutirmos acerca do método de produção. O documentário foi produzido por ocasião do $250^{\circ}$ aniversário da cidade de São Paulo.

\footnotetext{
${ }^{7}$ Ver ANEXOS A, B, C e D.
} 
Posteriormente à exibição, marquei reunião com ele para discutirmos sobre os procedimentos de pesquisa e escolha de personagens. Havia notado que esse processo tinha elementos comuns ao meu projeto e poderia me ensinar muito.

O documentário "Cosmópolis" mostra uma gama de imigrantes e/ou migrantes que vieram para São Paulo. São personagens muito interessantes e peculiares. Nota-se que houve um grande trabalho de pesquisa. Segundo Camilo, havia duas pesquisadoras, que desenvolveram uma ficha com informações básicas relevantes da pesquisa: nome completo, endereço, local de origem, profissão etc. Foram pesquisadas e selecionadas, inicialmente, cinquenta e sete pessoas.

A partir daquela ficha-modelo, elaborei outra, adaptada para as informações relevantes das pessoas pré-entrevistadas no projeto Espanhóis. No entanto, à medida que comecei a usá-la, constatei que havia muitas informações que não cabiam naquele quadro. Ou seja, as informações estavam muito condensadas. Então, resolvi fazê-la em formato de perguntas e respostas. Esse formato constituiuse em importante documento para a equipe de produção e direção. Com os questionários em mãos, pudemos escolher os personagens que seriam gravados em audiovisual.

Os questionários foram importantes recursos de informação, pois as descobertas interessantes, surgidas durante as pré-entrevistas, ficaram registradas e serviram de subsídio para nortear e aprofundar os questionários posteriormente elaborados para as gravações. No início das gravações, as perguntas eram, basicamente, as mesmas da pré-entrevistas. Porém, aprendemos, ao longo do processo, que poderíamos, a partir das pré-entrevistas, reelaborar questionários "personalizados", de acordo com as experiências vivenciadas pelas pessoas. 


\title{
3.4 Escolha dos personagens - início da construção do discurso em formato de documentário
}

A partir da escolha dos personagens começa a se delinear a construção do discurso do documentário. Discurso esse que tem caráter de argumento, de retórica, para Nichols (2005), assim como o documentarista assume o papel do orador:

\begin{abstract}
Como o orador de antigamente, o documentarista fala das questões cotidianas, propondo novas direções, julgando as anteriores, avaliando características de vidas e culturas. Essas ações caracterizam o discurso retórico não como "retórico" no sentido da argumentação pela argumentação, mas no sentido de comprometimento com questões prementes de valor e crença, para as quais nem fatos nem lógica oferecem orientação conclusiva, que leve a uma conduta adequada, a decisões sábias ou perspectivas inspiradas. A voz do documentário atesta seu engajamento numa ordem social e sua avaliação dos valores subjacentes a essa ordem. É a orientação específica para o mundo histórico que dá ao documentário sua voz própria. (NICHOLS, 2005, p. 92).
\end{abstract}

Desde o início do processo de produção, no embate e no encontro com os personagens no contexto do mundo histórico, constrói-se o discurso, que, no documentário, denomina-se voz. Ainda segundo Nichols (2005), as narrativas dos personagens se constituem como parte dessa voz a ser construída por meio de outros recursos estilísticos de produção e direção (narrativa com voz over, ruídos, trilhas sonoras, imagens de arquivo de filmes, iconografia e edição).

O procedimento da edição consistiu na segunda instância da construção da narrativa, da voz. As opções de escolha da edição apoiaram-se nas narrativas acerca das hipóteses que havia elaborado anteriormente com relação ao foco das entrevistas: as construções das identidades culturais, pois o indivíduo contemporâneo tem suas entidades fragmentadas.

O critério de seleção contemplou também as narrativas que surpreenderam com caráter inovador, criativo e até contraditório das hipóteses, na minha posição de 
aprendiz de diretora documentarista. Conforme Nichols (2005), o trabalho assume o caráter de retórica, no sentido de comprometimento com questões prementes de valor e lógica. Concordo com o autor quando postula que a voz do documentário atesta seu engajamento numa ordem social e sua avaliação dos valores subjacentes a essa ordem.

A pesquisa de personagens traz o elemento inédito e inesperado quando deparamos com o mundo histórico. Fui surpreendida ao deparar com uma mulher com a experiência de vivenciar, simultaneamente, as identidades espanhola, valenciana, brasileira e japonesa, como a senhora Maria de Los Angeles Tallada Sato, ao longo de sua vida. Quando perguntei a ela como lida com tantas culturas ao mesmo tempo, ela respondeu, rindo: "É una confusión?"

A partir de minha imersão no mundo histórico, em contato com as pessoas e suas vivências, fui percebendo que minhas ideias e hipóteses sobre o tema ganhavam mais vida, enriquecimento, dimensões reais e multifacetadas, acima de tudo humanas, à medida que fazia as pré-entrevistas. Desde esse momento, delineou-se um processo de autoria, tão importante no documentário.

Pensando nas questões pessoais e existenciais que me levaram a trabalhar com esse foco, à medida que conversava com as pessoas, constatava que elas também tinham dilemas, aspectos positivos e negativos ao lidar com a construção de suas identidades culturais. E o modo como elas lidavam com esse assunto em seu cotidiano enriqueciam meus questionamentos internos, possibilitando a compreensão da dimensão sociopolítica e psicológica do tema.

Estava aprendendo a elaborar outros pontos de vista sobre o que significou todo o processo histórico e social da emigração de milhões de espanhóis de suas terras. E conhecendo as repercussões psicológicas desse êxodo que gerou traumas, 
em grande medida irreparáveis, pude compreender muitos aspectos da personalidade de meu pai e como seus traumas e suas neuroses ressoaram em mim. Em última análise, o contato com os espanhóis era o espelho por onde os via, por onde me via e por onde via a meu pai. Só me conheço pela interação com o outro; e, segundo D'Almeida:

\begin{abstract}
A identidade só pode ser construída por contrates: ao me deparar com o outro, se, em lugar de buscar explicá-lo, eu buscar compreendê-lo, terminarei por reconhecê-lo e, por contraste, por reconhecer a mim mesmo. O "eu" vai se constituir na troca, ou no diálogo com o outro. Verei a mim mesmo aquilo que eu e o outro temos em comum e também como aquilo que há em mim, mas não reconheço no outro. (D'ALMEIDA, 2008, p. 186).
\end{abstract}

Nesse primeiro momento da produção, o embate e o encontro com os personagens possibilitaram-me refletir e elaborar melhor essa questão projetiva do trabalho e tão cara a mim: estava investigando as construções das identidades dos imigrantes espanhóis, assim como também estava investigando a construção da minha identidade cultural. Essas interações e a criação de amizades e vínculos, como expressões de confiança e afeto, foram fundamentais para minha elaboração interior e para as elaborações dos entrevistados.

Segundo o pressuposto da história oral postulado por Meihy (1996), em uma relação de alteridade, faz-se necessário reconhecer e aceitar o outro. Ele menciona que essa relação se estabelece no momento da entrevista em história oral. Mas, no caso da produção do documentário, propus-me a trabalhar com o pressuposto desde o momento de aproximação aos entrevistados.

\title{
3.5 Percepção de se trabalhar com colaboradores - pré-entrevistas
}

Um dos primeiros aspectos que pude notar desde o início da pesquisa de personagens foi o significado de se trabalhar com as pessoas no contexto de suas 
vidas, ou seja, trabalhar com o mundo histórico. O trabalho do documentarista é o de representar parte do mundo histórico. E o que significa isso?

Significa que o documentarista, na melhor das intenções, "entra" na vida das pessoas e elabora um "retrato" delas.

No processo de produção, na pesquisa de personagens, percebe-se que a vida das pessoas é muito dinâmica, povoada de contingências e tem autonomia e ritmo próprios. Desde o início das pré-entrevistas foi preciso conversar, negociar, ajustar o momento apropriado para gravarmos. Ou seja, um "encaixe" na vida das pessoas. Como estabelecer estes encaixes? Por meio das negociações. De acordo com Lins (2007), documentário é negociação em todos os procedimentos: pesquisa e personagens, gravação e edição.

Tive a oportunidade de refletir sobre isso, pois deparei, logo no início do processo, com situações que me exigiram tal reflexão: conversei com uma senhora da comunidade valenciana, Maria Consuelo Sevilla Casan, que contou sua história de vida, somada à grande habilidade de narração e percepção. Sem dúvida se constituiria em personagem de relevância.

Entretanto, quando expliquei o conteúdo da entrevista e os temas abordados, ela argumentou de forma categórica: "gostaria muito de dar essa entrevista, mas no momento estou passando por um processo de separação litigiosa" de uma relação conjugal de trinta anos. Como ela narraria sua vida sem mencionar o momento particular (da separação) vivenciado? Ou iria torná-lo público?

Isso me fez refletir sobre o que Nichols questiona: "O que fazemos com as pessoas quando filmamos um documentário?" (NICHOLS, 2005, p. 31).

Essas questões éticas logo vieram à minha mente. E foram elas que auxiliaram na decisão de não gravarmos a entrevista naquele momento, para 
preservar sua vida privada e sua integridade psicológica. Concordei com Maria Consuelo: seria melhor esperar passar essa fase.

Outra situação peculiar aconteceu com a Sra. Maria de los Angeles Tallada Sato. Ela é uma pessoa alegre, espontânea e tem uma história de vida rica, no que diz respeito às vivências de sua identidade cultural. Ela é valenciana, tem filhos brasileiros e é casada com um filho de japoneses. Ela me contou que morou com a família por vários anos no Japão. Seu esposo estava no país, trabalhando e vivendo com um dos filhos.

Com a crise mundial, eles resolveram visitar a família no Brasil e, depois, contaram a ela que estavam voltando definitivamente para São Paulo. Vieram o esposo, o filho e a nora japonesa para sua casa. Todos recomeçando suas vidas sem terem trabalho nem lugar onde morar. Por outro lado, ela tem uma filha que estava no final da gravidez e que Ihe dava assistência como mãe. Sua vida tinha mudado completamente do dia para a noite. Estava recepcionando as pessoas de sua família e provendo a casa com tudo de que eles necessitavam. Sua casa e sua vida estavam cheias!

Ela comentou que não teria condições de gravarmos em sua casa, apesar de querer conceder a entrevista. Constatei que, naquele momento, ela estava sobrecarregada, preocupada e que não teria espaço em sua vida para gravarmos a entrevista.

\subsection{Meus embates interiores}

Desde as pré-entrevistas, os embates foram surgindo: pode-se considerá-los de natureza profissional, psicológica e ética. 
Os embates profissionais se deram a partir de minhas atuações no processo de produção. Neste capítulo, mencionarei apenas os que correspondem ao procedimento de pesquisa de personagens. Nessa etapa, atuava como diretora, mas, em grande medida, como produtora. Esta vivência está introjetada tão fortemente que se manifesta naturalmente.

A ideia do deslocamento profissional sempre esteve presente, na medida em que me via e me sentia transitando de um lugar para o outro - da produção para a direção. Preocupava-me o desenvolvimento das conversas nas pré-entrevistas, pois partia da perspectiva da gestão do tempo da produção, de um tempo limite estabelecido interiormente por mim, no papel de produtora, para as pesquisas de personagens.

No contato com as pessoas, porém, percebia que esse prazo se excedia, porque, durante as conversas e negociações, levava em consideração o ritmo psicológico das pessoas e de suas vidas. Elas não estavam em casa quando ligava, não podiam falar em certos momentos ou não se sentiam psicologicamente preparadas para gravar nos dias que tínhamos disponíveis. Mas, diante de todos esses fatores, o que prevalecia era o respeito por elas, princípio postulado pela História Oral no aspecto relacional entre entrevistado e oralista (diretora).

Respeito esse que contemplava até a possibilidade de não gravarmos se a pessoa não quisesse, independentemente do motivo. Eis aqui um aspecto profissional associado ao ético/humano aprendido na produção do documentário.

Houve casos de homens que, ao convite para participar do projeto, gostaram da ideia e concordaram em ser entrevistados, como o senhor Juan Ramón Granero Marin. Queríamos entrevistá-lo por sua origem galega, por sua facilidade em narrar sua história de vida cuja trajetória apresenta aspectos relevantes. Sua esposa o 
incentivou a participar. No início das conversas, concordou, mas depois de alguns dias, disse que não queria ser entrevistado, alegando que "não queria aparecer".

Outro caso foi o do senhor José Luis Aragón e o filho. Eles são madrilenos. Fabiana, a produtora executiva, conhecia a família desde sua infância: eram vizinhos. Entrou em contato com eles e fez o convite. O filho disse que o estenderia ao pai.

Essa família tem uma trajetória de vida interessante. O filho foi estimulado pela família, na Espanha, a ser toureiro, pois seu tio havia sido um toureiro famoso que faleceu em plena arena, no embate com o touro. Aqui no Brasil, Pepito, como é chamado pela família, tinha todos os artefatos de um toureiro presos à parede de seu quarto. Entretanto, com a necessidade da imigração para o Brasil, seu pai fundou uma empresa para fabricação de bujões de gás e Pepito tornou-se o administrador da empresa do pai. Pensávamos em entrevistar avô, pai, e filho para termos as perspectivas de gerações diferentes.

Para qualificar nosso trabalho, Fabiana apresentou-me e ressaltou a minha ascendência espanhola, minhas credenciais profissionais e a envergadura acadêmica do projeto. Foram várias ligações e explicações. Todos os diálogos foram muito secos, não necessariamente diretos. Nunca foi falado um "não" com rigor. Levantaram toda a sorte de dificuldades para o primeiro encontro, a fim de nos conhecermos. Houve incompatibilidade de horários.

Além disso, já tínhamos escolhido um entrevistado da região de Madrid. E, naquele momento, a diversidade cultural era um critério de escolha fundamental. Por isso decidimos não gravar com eles. Ao final das conversações e negociações, eles consentiram a gravação da entrevista, para minha surpresa. 
Precisávamos de um homem galego, porque foi dessa região que vieram os maiores contingentes de espanhóis. Nessa pesquisa, chegamos a Liliane Mayo, filha de pai galego e mãe basca. Eles moram atualmente em um sítio no município de Sorocaba, onde plantam legumes e verduras para consumo próprio e produzem vinho.

A filha estabeleceu contato com a produtora executiva, Fabiana, e comentou sobre a personalidade dos pais. O pai era mais acessível, mas a mãe era uma pessoa mais fechada e brava. Só conversava com pessoas próximas a ela.

Fabiana estabeleceu diálogo com Liliane, trocaram e-mails e telefonemas, mas Liliane estava reticente.

Inesperadamente, na última correspondência, Liliane explicou que os pais estavam doentes e que ela se encontrava em dificuldades para lidar com a situação. A partir de então encerramos a tentativa da entrevista, pois constatamos a recusa transmitida de forma indireta.

Depois de tantas negativas e desistências das pessoas, a equipe de produção se questionou sobre quais os motivos de tais recusas para as entrevistas, a fim de compreender a situação. Solicitei orientação à Profa. Marília, que nos propiciou uma hipótese de interpretação: as pessoas sabem, mesmo que inconscientemente, que, à medida que elas narram, revisitam suas histórias, revivem os acontecimentos. Dependendo de como foram essas vivências do passado, o reviver pode não ser bem-vindo. Pode haver muitos traumas, medos e infelicidade envolvidos, com que elas não querem entrar em contato novamente.

Com esse esclarecimento, senti-me mais tranquila, pois, ao deparar com tantas negativas à participação, cogitei até a possibilidade da inviabilização das 
gravações. Mas, paralelamente, estávamos conversando com outros espanhóis que concordaram em gravar as entrevistas.

Conforme falava com as pessoas, percebia que a aceitação das entrevistas se dava porque elas comungavam das questões que estava levantando, ou porque achavam importante produzirmos um documentário (com significado e expressão de documento) sobre a imigração espanhola em São Paulo, já que não existia nenhum outro sobre esse assunto. Outras pessoas pareciam que sentiam falta de serem ouvidas e de terem um produto audiovisual em que pudessem estar representadas; e demonstravam que aceitavam gravar as entrevistas também em sinal de confiança e credibilidade ao nosso trabalho, às nossas amizades. Afinal, todos sabiam que iriam tornar públicos muitos aspectos de sua vida privada.

Estas percepções estavam fundamentadas no processo de aproximação à perspectiva de Trinh T. Minh-há, o "falar de perto". Conforme explicava sobre o projeto do documentário e me aproximava dos imigrantes, acontecia o processo de construção do falar de perto. Tal aproximação se estabelecia por meio da escuta atenta, do respeito e da relação dialógica a que se refere Meihy (1996) quando menciona o tipo de relação a ser estabelecida entre entrevistado e oralista (diretora).

As descobertas psicológicas de identificações e de estranhamentos com a cultura espanhola surpreenderam-me porque estavam inconscientes até então para mim. Várias vezes, assustava-me por constatar aspectos dos valores espanhóis em questões cotidianas da minha vida e da vida das mulheres pré-entrevistadas. Lembro que quando desliguei o telefone após falar com a Senhora Carmen Baena, de Sevilla, percebi que tinha atitudes parecidas com as dela, no exercício da função de dona-de-casa. Fui percebendo as mesmas identificações à medida que conhecia Carmen Acirón, de Valência. 
Para elas, a casa é uma extensão de seus corpos. Por isso suas casas precisam estar sempre bem cuidadas e limpas. Essas atitudes são expressões de um lado feminino que cuida.

Outro aspecto do feminino é a nutrição. Nutrição de quem? Da família, que tem papel de destaque em suas vidas: é o núcleo principal. O ato de cozinhar com prazer, amor e cuidado simboliza a nutrição (física e espiritual) dessas famílias. Em última análise, é o manter acesa a chama da vida e da cultura por gestos singelos, mas imprescindíveis.

As duas espanholas (Mari Carmen e Carmen Baena) sabem e gostam de fazer comidas espanholas e brasileiras, como eu. É na comida e no ato de comer que se situam os elementos integradores das diferentes culturas na convivência dessas famílias. Detalhe importante: na hora da comida, não há vez para as discussões e embates. Apenas o degustar dos alimentos pelo prazer de um bom paladar. Momento raro na família espanhola: Paz!

Os embates e estranhamentos com os quais deparava na convivência com Carmen Acirón se davam, em alguns casos, por suas posturas e atitudes no exercício da presidência do Centro Valenciano, na maneira como ela conduzia as relações com outros grupos de espanhóis, por meio de embates e do medir forças pela competição. Nesses momentos, sentia-me muito brasileira, pois não via necessidade de se estabelecer tal relação na dimensão da competição.

Essas descobertas constituíram-se em substrato para minha elaboração interior no sentido da busca da minha identidade cultural, como um processo metafórico de "esculpir" dentro de mim a mulher que tenho plasmado e buscado há muito tempo. O fato de me identificar com essas mulheres espanholas foi o caminho de aceitação e a porta de entrada para minha identidade espanhola. 
Caminho esse conduzido pela perspectiva feminina: a afetividade, a reflexão minuciosa, o acolhimento, a compreensão, o carinho e o amor. Eles foram decisivos para dissipar os traumas, as dores, os bloqueios e "trancas" desenvolvidos até então, frutos dos mal-entendidos na convivência com meu pai e, por continuidade, na convivência comigo mesma, expressa na negação da identidade espanhola.

Ao final do processo de pesquisa de personagens, optamos por gravar quatro pessoas de diferentes regiões e cidades espanholas, que serão apresentadas por meio de seus perfis. Esses perfis refletem as informações colhidas nos questionários da produção das pré-entrevistas.

\subsection{Perfis dos entrevistados escolhidos}

Depois de preencher cada questionário da pré-entrevista e de adicionar informações trocadas por telefone e pessoalmente, elaborei o conteúdo do perfil de cada entrevistado. O objetivo era fornecer o maior número de informações sobre as pessoas para a equipe de produção nas gravações e, principalmente, para o diretor musical, que necessitava de mais elementos para a criação das primeiras diretrizes do desenho sonoro.

\subsubsection{Carmen Baena Fernandez}

Origem: Andaluzia - Sevilha

Idade: 74 anos, viúva. 
Viúva há seis anos, mora sozinha atualmente na casa em que vive há trinta e cinco anos. Sua casa é bem cuidada do ponto de vista de conservação da arquitetura. Dentro dela, havia uma arrumação - que geralmente compete à mulher -, que expressava o zelo na disposição, organização e limpeza dos móveis e objetos. Pela figura de seu marido, na pequena fotografia do porta-retrato, percebi um homem dedicado à família. Talvez esse cuidado na conservação da casa seja a maneira que ela encontra de perpetuar a presença dele e compartilhar o que pensavam em comum.

Dona Carmen não costuma passar muito tempo em casa. Sempre arranja o que fazer e aonde ir. Faz ginástica no "Centro Esportivo de Pirituba" e sai com as amigas.

Tive a impressão que, para ela, é muito difícil ficar sozinha na casa onde toda a família morou e onde os filhos (dois homens casados) cresceram. Ou seja, a casa evoca muitas lembranças de sua vida, de sua história e de sua família. Bastava notar os vários porta-retratos espalhados pela pequena sala. Parecia que eles eram a companhia dela, já que as pessoas não estavam mais presentes. Ou é por meio deles que ela talvez articule emocionalmente a presença/ausência da família. Ela gosta muito dos netos, uma menina e um menino, com sete e nove anos.

Ela me pareceu uma pessoa simples e de poucas palavras. Pelo menos ficou claro para mim que ela simplesmente vive sua vida sem refletir sobre ela, porque parece que isso não é importante.

Enquanto conversávamos, suas reações às perguntas eram demonstrações de que aquilo tudo não era importante, de que sua vida não era algo relevante. Suas respostas eram monossilábicas. 
Empreendi um esforço grande para "chegar ao seu mundo". Mas senti que era difícil. Esse esforço seria correspondente ao speakig nearby proposto por Trinh T. Minh-há, para a aproximação com os entrevistados.

Somente em um momento seu rosto fez uma expressão de "agora você está chegando perto de mim". Depois de perguntar sobre como era sua vida e seus hábitos, quis saber: e a solidão? Sua reação foi instintiva: abriu um sorriso e respondeu algo como: "É difícil! Meus dois filhos casaram e agora estou sozinha!" Nesse momento senti que estava 'falando de perto' com ela.

Comentei com PC que nos restava um desafio pela frente: como representaríamos uma pessoa que não fala muito? De acordo com o método de Coutinho, consideramos os silêncios, as expressões corporais, as hesitações, a fim de construir o personagem na gravação e, posteriormente, na edição.

Por que gravamos sua entrevista? Porque ela é uma pessoa simpática, amorosa e espirituosa. Pessoa rara, de grandiosidade fenomenal. Mulher honesta e dedicada.

Mostrou-me as músicas de que gosta. Emprestou-me alguns CDs para ouvir e incluir na pesquisa de áudio para a direção musical.

Enquanto via seus CDs (havia um com duas "cantantes" de meia-idade) tive um insight: perguntei-Ihe se toda garota sevilhana tinha o sonho de ser cantora e dançarina de flamenco, se ela tinha esse sonho e se tentou realizá-lo.

Ela respondeu que era evidente que sim, mas que não conseguiu porque trabalhava muito em Sevilha. Pensei nas representações que existem no imaginário das pessoas e no confronto com a realidade. E como ficam esses sonhos e desejos para uma mulher como ela? Como representaria, no documentário, muito do que 
aconteceu em sua vida entre esse sonho e a pessoa que é? Entre o sonho imaginado e a realidade vivenciada?

No final do encontro, expliquei-Ihe sobre as entrevistas, os temas, assuntos e convidei-a para participar das entrevistas. Ela ficou muito reticente. Disse que iria pensar.

Depois do primeiro encontro, conversamos algumas vezes por telefone. Disse que havia ouvido todas as músicas e tinha gostado muito. Mas ela ainda estava indecisa para gravar. Resolvi fazer outra visita à casa dela.

\section{Segunda visita à Carmen Baena}

Na última vez em que conversamos, por telefone, ela disse que não se sentia à vontade para gravar a entrevista. Quando Ihe expliquei qual era a ideia da gravação, de gravar a preparação do personagem, ela teve uma reação de estranhamento e desconforto. Mas não falou nada.

Então, nessa segunda visita, tivemos uma conversa franca. Disse a ela como me ocorreu a escolha de gravar com ela. Foi uma história curiosa: seu filho, Arturo, mora no mesmo prédio que meus pais. São vizinhos de garagem. Encontraram-se certo dia e travaram diálogo inicial.

Meus pais iam me contando as histórias à medida que elas aconteciam, até que um detalhe chamou-me a atenção. Minha mãe comentou: "Bel, ele é um moço muito bem educado. Isso me fez pensar que, se ele é assim, a educação dele, em grande parte, se deve à sua mãe. Imaginei que essa mulher merece ser ouvida e que tem muita coisa interessante para contar". 
Pedi o número do telefone de Carmen e liguei para convidá-la a participar das gravações. Ela concordou depois de certa resistência. Mas disse que as cenas de preparação do personagem eram muito estranhas a ela. Eu disse a ela que se não se sentisse à vontade não gravaríamos.

$\mathrm{Na}$ tentativa de me aproximar mais do mundo dela ('falar de perto'), comentei sobre as músicas do CD que havia ouvido (Los romeros de La Puebla) e de que tinha gostado muito. Ela me disse que então eu gostaria de outros que possuía. Mostrou-me os outros e os emprestou para eu copiar.

Saí de lá mais tranquila, pois senti que ela não estava mais incomodada nem contrariada com a situação. Além disso, também sugeri que pensasse bem e, se não quisesse gravar, ficaria tudo bem, não se faria nada a contragosto. Mais uma vez procurei garantir que o compromisso de respeito aos entrevistados fosse considerado.

Ainda nessa visita perguntei a ela de onde vem esse costume de zelar tanto pela casa, se era do seu marido. Ela disse que é um valor da região de onde vieram. Para eles, é mais importante ter uma casa bem cuidada do que um carro, como aqui em São Paulo. Essa foi uma construção comum desse valor/costume (dela e do esposo) desde que eram jovens. Começaram a namorar quando eram adolescentes, eram vizinhos. Conseguir manter esse costume como um dos laços e vínculos da filosofia conjugal até o fim da vida é algo louvável e heroico! No dia da gravação, seria importante gravar (com a câmera móvel em panorâmica, em planos fechados) as paredes da sala e o rack da TV, com muitos retratos da família próxima e ampliada (a que está na Espanha). Ali, todos convivem; pelo menos ali, naquele espaço do seu cotidiano e de sua vida. Nesse espaço de expressão de sua 
subjetividade e afetividade, não há milhares de quilômetros de distância geográfica que separa os dois países e as pessoas da família.

A cozinha também fala muito de sua personalidade de mulher, dona-de-casa. Tudo muito cuidado e organizado.

Depois dessa visita, promovemos um encontro para meus pais conhecerem Carmen. Seu filho Arturo a levou, juntamente com sua família, até o apartamento deles. Conversaram e meus pais comentaram como foi a experiência da gravação da entrevista. Disseram que foi uma experiência boa e que eles desfrutaram. Enfim, todos a encorajaram a gravar a entrevista. No final ela se prontificou a agendar a gravação.

\subsubsection{Mari Carmen Acirón Rius}

Origem: Valência

Idade: 63 anos, casada.

Profissão: Presidente do Centro Valenciano de São Paulo e dona-de-casa (mas esta última identidade ela não gosta de revelar, pois acha que a desvaloriza).

Ela foi a pessoa que mais conheceu o projeto. E a que eu mais conheço. Segundo MacDougall (1995, p. 116), uma situação é conhecer a pessoa na vida real. Outra bem diferente é construir o personagem na gravação e, depois, continuar a construir esse personagem na edição. Segundo ele, nesse processo há várias “mortes". Acredito que o personagem construído na edição será bem diferente, talvez mais pobre do que a pessoa em si. 
Carmen tem três filhos, dos quais se orgulha muito. Dois são casados: mais velho, Carlos, e a filha do meio, Paula. O mais novo, Sérgio, não é casado. A família é a instituição mais importante para ela. "A família é tudo!” E ela é a matriarca!

Os três filhos são advogados, profissão que ela gostaria de seguir. Quando se casou, parou de trabalhar e não pôde estudar. Hoje, ela se realiza nos filhos.

Seu marido é português, e isso tem possibilitado a ela um "trânsito" de culturas muito grande.

Ela gosta de cozinhar. Tem muitas revistas e livros de receitas. Aprendeu a fazer comida portuguesa por causa de seu marido. A comida espanhola, aprendeu com a mãe e, mais tarde, nos livros. O Centro Valenciano recebe muitas publicações dessa natureza. Por exemplo, há um livro sobre diversas maneiras de preparar o arroz, porque Valência é uma cidade produtora de arroz da Espanha.

$\mathrm{Na}$ área da gastronomia, Valência sempre foi o local de origem da paella. Ela sabe da história e explicou na gravação. Pôde também contar que comidas sua mãe fazia e como preparava.

Carmen é uma pessoa muito alegre. Sabia bem da intenção da gravação, o que me fazia temer que ela se excedesse no seu personagem, que atuasse com espírito de overacting.

Quando expliquei sobre nossa ideia de gravarmos a construção e preparação do personagem ela resumiu: "Já entendi, vou pensar em como construir minha falsa aparência!".

Carmen é autodidata. Gosta de literatura, jornais, revistas. Está muito atualizada com o que acontece em Valência. Também gosta de ler e declamar poesias. Durante a entrevista, pedi a ela que declamasse uma poesia de que gostasse, mas ela não lembrou. 
Por meio dessa convivência com o conhecimento, ela tem construído seu mundo sensível e imaginativo. E, na entrevista gravada, expressou de diferentes maneiras sua cultura subjetiva. Sua narrativa foi articulada de forma engenhosa e imaginativa a ponto de criar situações e personagens imaginários.

Por meio da música, da poesia e da leitura, ela tem acessado essa dimensão de sua existência, sua cultura subjetiva. Esse tem sido um aspecto positivo e prazeroso para ela; a partir desse lugar, ela tira sua inspiração.

Carmen é cinéfila. Lembra-se de filmes de Hollywood da época de ouro e tem assistido aos filmes contemporâneos da televisão a cabo.

Vivenciou o pós-guerra, que, segundo ela, há quem diga que é pior do que o período da guerra. Contou sobre o cinema, o que assistiam e como eram as sessões.

O fato de ser presidente do Centro Valenciano a faz sentir "mantendo a chama acesa" da sua cultura de origem e também lhe proporciona certo status social. Ela mencionou que faz isso por causa de sua mãe, valenciana. Seu pai era madrileno.

Sua mãe gostava de cantar zarzuelas. Carmen lembra-se dessas músicas e gosta de cantá-las. Pedi a ela que cantasse algumas zarzuelas. No momento da gravação, ela lembrou-se apenas de pequenos trechos.

Seu gosto musical é eclético, segundo ela. Gosta de gêneros brasileiros, portugueses e espanhóis. Costuma lembrar-se de muitas letras e canta-as com facilidade.

Para ela, suas identidades culturais são: cinquenta por cento brasileira, porque chegou aqui com dez anos, e cinquenta por cento espanhola. Depois, questionei sobre sua identidade valenciana. Ela acrescentou: "E cinquenta por cento 
valenciana!". Quando comentei com PC sobre esse aspecto, ele foi perspicaz: "Mulher cento e cinquenta por cento!". Ela me falou de como se sente como imigrante: como um girassol. Raízes no chão e a flor olhando para o lado oposto: Brasil e Espanha. Perguntei sobre esse sentimento na entrevista gravada. Ela explicou seu raciocínio. Essa metáfora pode se constituir na forma com ela vivencia o que postula Hall (2000), a fragmentação do sujeito contemporâneo.

Sua casa é pequena. A cozinha é o cômodo vizinho à sala. Ela organiza-a e arruma-a frequentemente; afinal, sempre diz que uma mulher precisa cuidar bem de sua casa e de sua família!

A casa reflete sua personalidade, tem um ar de casa de gente zelosa, carinhosa, muito organizada e limpa, com as coisas em seus lugares certos. Mantêla assim é uma tarefa árdua, levando-se em consideração que todo o trabalho doméstico é feito por ela. Seu marido quase não a ajuda, apesar de estar o tempo todo lá.

Ela tem uma cachorra vira-lata de que gosta muito, chamada Kelly. Fica no quintal, mas quando Carmen está na cozinha, a cachorra vai até a porta para "chamá-la".

Carmen tem uma vaidade própria. Gosta de se maquilar sempre antes de sair. Pinta os olhos com delineador preto, típico da mulher espanhola, e pinta suas sobrancelhas também. Produzi essa situação para gravarmos. Por outro lado, não cuidou muito de sua saúde e engordou bastante após a primeira gravidez. Ela mostrou, na gravação, fotos suas de quando tinha 35 anos. Estava bem mais magra e, segundo ela, era muito bonita! "Ahora estoy um trasto!" 


\subsubsection{Margarita Riudoms Fernandez}

Origem: Catalunha

Idade: 68 anos, divorciada.

Margarita era casada com meu tio Manolo, irmão do meu pai. Crescemos junto com os filhos dela, que consideramos primos-irmãos: Ricardo, que hoje tem quarenta e sete anos, e Lolita, quarenta e dois. Ele é filho do primeiro marido de minha tia, um catalão chamado Ricardo. Só descobri essa passagem da vida dela por meio do questionário. Sempre pensei que ela tinha se separado na Espanha e vindo para o Brasil com o filho bem pequeno, com apenas cinco anos.

Mas a versão correta dessa passagem de sua vida é que a família veio e Ricardo, o pai, voltou. A relação acabou, mas não sabia por quê. Talvez ele não tenha se adaptado aqui. Tentaria perguntar isso para ela durante a entrevista.

Em geral, a atitude de minha tia frente às situações vivenciadas com relação à Espanha é de muita dureza. Parece-me curioso, pois ela tem um lado sensível. Ela é muito generosa. Durante toda a nossa infância, ela levava presentes de aniversário para minha irmã e para mim.

Ela sempre teve uma mentalidade, em grande medida, liberal. Em outra medida, conforme fui crescendo, percebi algumas incompatibilidades em seus pensamentos e atitudes.

Minha relação de afetividade e carinho com ela vem desde a infância. Ela acompanhou toda a nossa trajetória de vida, e discutia muito com meu pai sobre suas ideias e atitudes retrógradas com relação à nossa educação. 
Da minha parte, a afetividade é bem grande, pois via nela e em meu tio Manolo características de tios amigos. Era muito bom ver a amizade, atenção e carinho que meu tio dava para seus filhos e para nós.

Ela sempre trabalhou. Contou que sua família era bem humilde na Espanha. Desde o início, trabalhou em comércio. Antes de vir ao Brasil, trabalhava em uma loja de frios do mercado central de Barcelona.

Depois que chegou ao Brasil, foi trabalhar na BIART - Bijuterias Artísticas -, uma pequena fábrica de bijuterias de um casal catalão. Ela trabalhou lá por cerca de trinta anos. Depois, abriu um comércio próprio.

Separou-se do meu tio Manolo e até hoje mora na casa em que viveram juntos.

Atualmente, tem uma loja pequena na vila Mazzei, zona norte da cidade, de biquínis e roupas de ginástica, que se chama "Mare Nostrum". Segundo ela, era o nome que Ernest Hemingway dava ao Mediterrâneo.

No Brasil, ela sempre teve muito acesso à vida cultural: gosta muito de ler e frequenta teatro. Contou-me que gostava muito de assistir a peças com Bibi Ferreira, Eva Vilma, Paulo Goulart, Nicete Bruno, entre outros. Perguntei sobre isso para ela na entrevista. Ela revelou, na gravação, que começou a frequentar o teatro com seu pai aos quatro anos.

Tem vivido sozinha em casa e trabalha em sua loja. Em casa, gosta de navegar na internet. Tem vários amigos (brasileiros e espanhóis) na rede. Esse recurso também a ajuda a ver Lolita e a falar com ela, que vive na Espanha há cinco anos. Acho que elas têm estado conectadas frequentemente. Lolita preocupa-se muito com ela porque agora está só e com alguns problemas de saúde. Ricardo tem 
sua vida familiar, mas tem contato com a mãe. Ele se preocupa com ela e a auxilia nas despesas da casa.

\title{
3.7.4 José Luis Blanco Goicoechea
}

\author{
Origem: Madrid \\ Idade: 80 anos, casado. \\ Profissão: aposentado - gráfico encadernador.
}

Meu pai veio para o Brasil em 1958, com vinte e nove anos. Seu irmão menor veio com ele. Logo depois, seu irmão voltou à Espanha, pois não se adaptou no Brasil.

Segundo o questionário da pré-entrevista ele estranhou muito o Brasil e custou a se adaptar. $\mathrm{O}$ aspecto positivo de morar aqui foi conhecer minha mãe, ela é tudo para ele. Sempre viveu em função da família, sacrificando, inclusive, suas amizades.

Apesar de ele ter vivido a maior parte de sua vida aqui (cinquenta anos), afirma que não se aculturou em nada. Segundo ele, não incorporou nada da cultura brasileira: "Soy español hasta la medula!'

Perguntei, na pré-entrevista, se ele se sente espanhol ou estrangeiro quando viaja à Espanha. Ele respondeu que se sente espanhol, como o irmão mais velho dele, que viveu a vida inteira lá.

Minha mãe disse uma coisa interessante: quando eles viajam à Espanha, ele se transforma; parece outra pessoa, mais alegre e mais leve. Certa vez, ele 
confidenciou a João Pedro, meu filho, que seu maior desgosto seria morrer e ser enterrado aqui.

Ele tem vivido aqui de forma rotineira e sistemática. Tem ficado muito em casa e, na velhice, tem tendências à depressão. Sua alegria é ver os filhos e netos. Meu irmão mora nos Estados Unidos. Ele tem dois garotos, um de cinco anos e outro de dois anos. Quando estiveram aqui de férias, meus pais brincaram muito com as crianças.

Nossa educação (minha e da minha irmã) teve muita participação dele. As maiores virtudes, apreendemos dele. Sua ética sempre foi a do trabalho e a força de vontade de viver. 


\section{CAPÍTULO 4 \\ O MÉTODO DA PRODUÇÃO}

\subsection{Etapas do processo de produção e a ética do processo}

A reflexão desenvolvida neste capítulo tem como foco o método de produção e está orientada pelos estudos, debates e práticas desenvolvidos no grupo Aruanda lab.doc.

Há pouca literatura sobre este assunto. O que pudemos recolher de informação está entremeado, sobretudo, em entrevistas e depoimentos feitos por documentaristas em publicações variadas.

\subsubsection{Gerenciamento da produção}

\subsubsection{Demanda}

A demanda da produção do exercício prático partiu de duas necessidades: o ineditismo do tema da imigração espanhola anos 1960 na produção brasileira, em formato de documentário, e minha paixão pela cultura espanhola, que se constitui como minha segunda nacionalidade e que faz parte de minha história de vida.

\subsubsection{Financiamento}

O projeto contou com duas ajudas do governo espanhol, destinadas ao Programa de Proyectos e Investigación. As solicitações foram apresentadas, 
respectivamente, nos anos de 2007 e 2008, em nome do Centro Valenciano La Senyera, de São Paulo. Esses valores, de pequena monta, viabilizaram, sobretudo, a compra de material sensível e pequenos gastos de produção.

Há a ideia de buscar algum patrocínio que permita uma finalização de qualidade profissional, ao término da dissertação. Neste momento, o foco acadêmico do trabalho está sendo priorizado.

\subsubsection{A formação da equipe}

Com os limites estabelecidos ao projeto - base prática para a reflexão acadêmica - e os recursos financeiros limitados desta etapa, constituímos uma equipe comprometida com os mesmos objetivos de pesquisa do Aruanda lab.doc.O grupo ficou, então, assim constituído:

- Isabel (Bel) Blanco - direção;

- Paulo Cesar Toledo (PC) - direção de fotografia e câmera e edição;

- Fabio Cintra - direção musical;

- Fabiana Sanchez (Fabi) - produção;

- Wanderley Mastropaulo - assistente geral, câmera de apoio.

É preciso destacar que Fábio Cintra agregou-se ao grupo para este trabalho, a meu convite, pois não faz parte do Aruanda lab.doc. Fábio é professor doutor do CAC - Departamento de Artes Cênicas da Escola de Comunicações e Artes da USP - e é compositor, trabalhando com a sonorização de espetáculos. Sua integração 
com o grupo, no entanto, foi imediata e talvez continue participando de outros trabalhos e mesmo de nossas reuniões mais teóricas.

A oportunidade de produzir um exercício prático no marco acadêmico apresentou aspectos favoráveis e desfavoráveis. Dentre os aspectos favoráveis, houve disponibilidade de tempo para eu construir conhecimento, formação acadêmica e metodologias (acadêmica e de produção). Por meio dessa formação, pude elaborar a proposta estética do exercício prático. Ou seja, este foi um desafio inicial superado no sentido de assumir a concepção e direção e de um projeto autoral.

O período para desenvolvimento do projeto possibilitou a construção da metodologia de pesquisa acadêmica, no que diz respeito ao levantamento da bibliografia e ampliação de repertório audiovisual, por meio das disciplinas cursadas e da realização de pesquisas em acervos públicos e privados.

Com relação à construção da metodologia da produção do exercício prático, pude associar a experiência profissional, propor à equipe o trabalho coletivo como pressuposto básico de nossa construção do método de produção e a proposta estética com o tratamento (abordagem pessoal) dado ao tema. Assim, fomos construindo o método de produção próprio ao projeto e ao tema.

Os aspectos desfavoráveis dizem respeito à produção do exercício. Mesmo que estivesse inserido no contexto da universidade (Escola de Comunicações e Artes), a instituição não disponibilizou recurso algum (tecnológico, financeiro ou humano) para a produção. Essa iniciativa aconteceu por meio de parceria entre os integrantes do Aruanda lab.doc. O tipo de parceria estabelecido encontrava-se no âmbito da produção independente. 
Trabalhar no contexto da produção independente significou mais um aprendizado, pois sou profissional de uma emissora de televisão pública. Nesse contexto, os ritmos da criação e da produção estão condicionados à gestão da grade. Portanto, o cronograma e o planejamento da produção precisam ser rigorosamente obedecidos a fim de cumprir a grade de exibição.

No caso do exercício prático, o compromisso não era atender a uma grade de exibição, mas sim construir o método de produção e o conhecimento acerca da produção documental.

Na produção independente, não temos os recursos humanos, tecnológicos e financeiros disponíveis equivalentes aos de uma emissora de televisão. Para o gerenciamento do projeto, havia disponíveis recursos financeiros de pequena monta, recursos tecnológicos e humanos. A maioria da equipe provinha do Aruanda lab.doc. Havia um objetivo de relevância fundamental e comum: o compromisso e os objetivos dos profissionais confluíam com os objetivos de pesquisa do Aruanda lab.doc. Por meio desses recursos, foi possível estruturar a produção do exercício.

Os aspectos positivos vivenciados na produção independente e autoral dizem respeito ao envolvimento e compromisso de todos da equipe no processo de produção. Apresentei a proposta estética do documentário à equipe e cada profissional, de acordo com sua experiência, incorporou elementos e aprimorou-a, conforme nossa concepção do trabalho coletivo.

No caso do exercício prático, no contexto da produção independente, os profissionais sentiram-se livres para trabalhar e gerenciar prazos. Há mais possibilidade para discussão, criação, realização e construção de método em uma produção com essa característica. Tais construções e elaborações não seriam possíveis no contexto de uma televisão (pública ou privada), tampouco em uma 
produtora independente comercial, pois essas empresas têm como meta produzir o máximo possível em curto período de trabalho. Não há tempo para aprendizados e reflexões acerca da prática profissional.

A limitação dos recursos financeiros impôs alguns desafios que não conseguimos superar ao longo do processo das gravações. Constatei que as imagens captadas pela câmera móvel não expressavam a linguagem da proposta estética. Não dispúnhamos de recursos financeiros para contratar outro cinegrafista profissional.

Devido às restrições financeiras, tive de acumular várias funções o que acarretou problemas no desempenho da função da direção. Não consegui me dedicar como deveria na função de diretora.

Entretanto, posso afirmar que a oportunidade de construir um método de produção documental foi significativa e única. Foi possível conceber um projeto estético com lastro acadêmico e construir um método documental em todos os procedimentos da produção, por meio do desempenho da direção, função que me possibilitou o conhecimento mais elaborado e aprofundado acerca de tal produção; oportunidade vivenciada e aprendida somente na prática do exercício; conhecimento que não conseguiria construir como pesquisadora do grupo Aruanda, pois exige contato e embate com o mundo histórico.

A partir do desempenho na direção, pude constatar que a proposta estética, como projeto, no embate com o mundo histórico, foi modificada pela imposição das condições de produção. Portanto, o método de produção do documentário foi construído, em grande medida, no embate da gravação. 


\subsection{Procedimentos de produção}

\subsubsection{Pesquisas preliminares}

A questão da ética no documentário é discutida por Bill Nichols (2005, p. 40). Sua perspectiva é questionar a relação entre o documentarista e as pessoas que aparecem nos documentários. Esta reflexão está contemplada nos Capítulos 3 e 4, desde o processo de aproximação até o momento da gravação, e também é construída no contexto do Aruanda lab.doc. Refletimos sobre a questão da ética como elemento que perpassa todo o processo da produção.

Antes de expor quais foram as pesquisas preliminares realizadas ao longo do processo de produção, gostaria de explicitar os procedimentos de natureza ética e profissional adotados para utilização dos materiais pesquisados, e que serão posteriormente inseridos na finalização do documentário.

Compreendo que, para se utilizar os materiais de arquivo, não basta apenas ter acesso a eles sem autorização prévia. Na obtenção de tais autorizações, fundamento-me em procedimentos profissionais aprendidos durante o período em que exerci a função de pesquisadora audiovisual do Telecurso 2000.

Considerando que este exercício de realização tem apenas fins acadêmicos, as solicitações de uso de imagens e sons se limitaram aos entrevistados, que assinaram termos de cessão de uso de imagens, e as músicas (trechos) que utilizamos são apenas aquelas a que os entrevistados fazem referência ou cantam. Fora isso, a trilha sonora do exercício será original e composta para o procedimento da finalização. 
Além de todos os procedimentos de pesquisa mencionados anteriormente, a sistematização das informações é necessária para organização, arquivo e possível comprovação de quais imagens e sons foram utilizados. Essa sistematização foi elaborada por meio de listas, que serão arquivadas com os comprovantes e autorizações concedidos.

As pesquisas preliminares estiveram presentes em diferentes momentos da produção. No início do processo, houve a pesquisa bibliográfica e audiovisual.

A pesquisa bibliográfica destinou-se à fundamentação sobre o tema da imigração espanhola no Brasil e migração em São Paulo. Para fundamentar a concepção das perguntas das entrevistas, pesquisei os conceitos de cultura, identidade cultural, e memória, conforme mencionado no Capítulo 1.

A pesquisa audiovisual investigou filmografia, principalmente de documentários sobre a temática da imigração e migração, a fim de verificar como esse tema foi tratado do ponto de vista audiovisual e como seus realizadores representavam tais temas e pessoas envolvidas neles.

Os filmes também se constituíram em referências para conceber a linguagem da direção. Dentre os pesquisados, escolhi Viramundo ${ }^{8}$ e El viaje más largo ${ }^{9}$.

A pesquisa audiovisual também serviu de referência para representação da Espanha, na concepção da direção musical e de fotografia. A filmografia selecionada constitui-se principalmente por filmes de autoria de Carlos Saura.

\footnotetext{
${ }^{8}$ Viramundo (Dir. Geraldo Sarno, Brasil, 1965, 40 min.). A migração de nordestinos para o Estado de São Paulo e os problemas gerados pela inadaptação à sociedade industrial. Um dos episódios da série clássica "Brasil Verdade", produzida por Thomas Farkas. Informação obtida no site Terra. Disponível em: $<$ www.terra.com.br/cinema/festivais/true99_nacional.htm+geraldo+sarno+viramundo+sinopse\&cd=4\&hl=ptBR\&ct=clnk\&gl=br>. Acesso em: 18 jul. 2009.

${ }^{9}$ El Viaje más largo (Dir. Rigoberto Lopez, Cuba, 1987, 25 min.). Os chineses e sua presença na vida cubana como elemento integrante da mestiçagem nacional. História da imigração chinesa em Cuba. (Fonte: biblioteca do Memorial da América Latina).
} 
Foram pesquisados seus filmes de não-ficção, dentre eles, Ibéria ${ }^{10}$ Bodas de Sangue $^{11}$ e Flamenco ${ }^{12}$. Para a representação da Espanha com imagens históricas, a pesquisa contemplou Terra Espanhola ${ }^{13}$ e Guernica $^{14}$.

A equipe assistiu e discutiu todos os filmes sobre a representação da Espanha, mas não os adotamos como referências para a linguagem da fotografia, apenas para a direção musical.

A disciplina de pós-graduação "Antropologia visual: comunicação e narrativa" ampliou meu repertório acerca de diferentes possibilidades de produções realizadas por antropólogos.

10 Ibéria (Dir. Carlos Saura, Espanha e França, 2005, 120 min. Festival de Cannes, 99 min. Toronto International Film Festival e Argentina). Inspirado pela música do compositor espanhol Isaac Albéniz, mostra uma celebração que une a disciplina, a destreza e a paixão do flamenco com a música clássica, o balé e a dança contemporânea. Informação obtida no site imdb. Disponível em: <www.imdb.com/title/tt0443057/>. Acesso em: 18 jul. 2009.

${ }^{11}$ Bodas de sangue (Dir. Carlos Saura, Espanha e França, 1981, 72 min. Espanha, 67 min. Estados Unidos, 70 min. Argentina). Conta a história de dois jovens apaixonados, que são impedidos pelas suas famílias de ficarem juntos. O reencontro acontece justamente no dia do casamento da jovem com outro homem. Um trágico destino selará esse triângulo amoroso, retratado com a magia de uma das maiores expressões de arte da Espanha: a dança flamenca. Informação obtinha no site imdb. Disponível em: <www.imdb.com/title/tt0082088/>. Acesso em: 18 jul. 2009.

${ }^{12}$ Flamenco (Dir. Carlos Saura, Espanha, 1995, 100 min.). O filme evoca aspectos artísticos da Espanha e presta homenagem à cultura do país através de vários números de dança e música. Com as performances de cerca de 300 pessoas, entre dançarinos e músicos, são mostradas diversas variações do flamenco. Informação obtida no site imdb. Disponível em: <www.imdb.com/title/tt0113077/>. Acesso em: 18 jul. 2009.

${ }^{13}$ Terra Espanhola (Dir. Joris Ivens, Estados Unidos, 1937, 52 min.). A produtora "Contemporary Historians" foi criada para arrecadar fundos para um documentário a ser filmado durante a guerra civil espanhola. Com John Ferno e, inicialmente John dos Passos, que, ao abandonar a equipe, foi substituído por Ernest Hemingway, Joris Ivens foi a Fuenteduena, cidade próxima a Madri, para filmar o "front" do exército republicano. Um dos mais importantes filmes sobre a guerra civil espanhola. Informação obtida no site $i m d b$. Disponível em: <www.imdb.com/title/tt0029594/>. Acesso em: 18 jul. 2009.

${ }^{14}$ Guernica (Dir. Alain Resnain e Robert Hessens, França, 1971, 13 min.). Com o bombardeio da cidade basca de Guernica, Pablo Picasso traduziu sua emoção numa magnífica, mas terrível, pintura, que recebeu o nome da cidade martirizada. O filme de Resnains é baseado nas pinturas, desenhos e esculturas de Pablo Picasso, de 1902 até 1949, incluindo Guernica. Resnains já usa o seu famoso estilo de cortes e fades no filme. Informação obtida no site imdb. Disponível em: <www.imdb.com/title/tt0042528/>. Acesso em: 18 jul. 2009. 
Dentre a filmografia apresentada, pode-se destacar: Reassemblage ${ }^{15}$, Surname Viet Given Name $\mathrm{Nam}^{16}$ e Photo Wallahs ${ }^{17}$. Por meio do conhecimento dos filmes e da bibliografia, fundamento a direção do documentário em aspectos relevantes da direção desses realizadores.

No momento da produção, PC Toledo também realizou pesquisas em arquivos contendo imagens históricas da Espanha, no site do Travel Film Archive (www.travelfilarchive.com), que disponibiliza imagens para utilização gratuita, e de São Paulo, no site daCinemateca Brasileira (www.cinemateca.gov.br).

As pesquisas de personagens foram produzidas por mim. Juntamente com esta categoria elaborei outras relacionadas às necessidades de produção das gravações das entrevistas: pesquisa dos objetos biográficos e pesquisa iconográfica nos acervos pessoais.

$\mathrm{Na}$ pesquisa de personagens, as informações colhidas foram registradas e sistematizadas nos questionários da pré-entrevista, discutidos nas reuniões da equipe (ver ANEXOS A, B, C e D).

\footnotetext{
${ }^{15}$ Reassemblage (Dir. Trihn T. Mihn-há, Estados Unidos, 1983, 40 min.) A partir de um filme supostamente etnográfico sobre tribos do Senenegal, Mihn-há, na verdade, nos dá um filme que comenta sobre o cinema etnográfico e o perigo de categorizar outros povos. Informação obtida no site imdb. Disponível em: <www.imdb.com/title/tt0084577/>. Acesso em: 18 jul. 2009.

${ }^{16}$ Surname Viet Given Name Nam (Dir. Trihn T. Mihn-há, Estados Unidos, 1989, 108 min.). Este documentário explora as vidas de cinco mulheres que sobreviveram aos conflitos do Vietnã na contemporaneidade (1989). Ele também enfatiza a posição social inferior das mulheres vietnamitas na sociedade antes e depois da guerra, mas nenhuma das guerras destrói a força que cada mulher sente pelo seu país. Informação obtida no site Women make movies. Disponível em: $<$ www.wmm.com/filmcatalog/pages/c58.shtml+sinopsis+SUR+NAME+VIET+Given+Name+Nam\&cd=2\&hl=pt$B R \& c t=c \mid n k \& g l=b r>$. Acesso em 18 jul. 2009.

${ }^{17}$ Photo Wallahs (Dir. Judith MacDougall e David MacDougall, Austrália, 1992, 60 min.): Os renomados cineastas etnográficos, David e Judith MacDougall, exploram os muitos significados da fotografia neste profundo e penetrante documentário. O filme enfoca os fotógrafos de Mussoorie, uma estação montanhosa aos pés do Himalaia, no norte da Índia, cuja fama atrai turistas desde o fim do século 19. Informação obtida no site Berkeley Media. Disponível em:

<www.berkeleymedia.com/catalog/berkeleymedia/films/arts_humanities/photo_wallahs>. Acesso em: 18 jul. 2009.
} 
Aproveitei esses momentos de diálogos e visitas às residências dos entrevistados e realizei pesquisa prévia nos acervos particulares (documentos, cartões postais, cartas, livros etc.). Esse material foi escaneado e arquivado.

A pesquisa do acervo sonoro de cada personagem também foi iniciada nesse momento. O diretor musical, Fábio Cintra, orientou-me no sentido de investigar quais as músicas e CDs que cada entrevistado gosta de ouvir. Nos dias de gravação ele pesquisou junto aos entrevistados e levantou mais material sonoro.Meu procedimento foi emprestar os CDs mais significativos e copiá-los, para fins da produção, para o diretor musical ter acesso ao acervo sonoro dos entrevistados.

Para compor a pesquisa de gêneros musicais, provenientes de diferentes regiões da Espanha, Fábio Cintra e eu pesquisamos no acervo da biblioteca do Instituto Cervantes, em São Paulo. Dentre o material, havia CDs como o gênero de Pasodoble ${ }^{18}$, "Suspiros de España", e da música regional "La música arábicoandaluza".

Nessa pesquisa inicial, o diretor emprestou alguns CDS que julgou diferentes dos gêneros de seu acervo particular. Ainda serão feitos mais levantamentos de imagens e sons quando da elaboração do roteiro de edição.

\subsubsection{Roteiro de gravação}

O roteiro de gravação foi desenvolvido a partir das informações colhidas no questionário da pré-entrevista, primeiro documento de produção, e do perfil de cada entrevistado, elaborado por mim depois de cada visita às locações.

\footnotetext{
18 Baile espanhol de ritmo rápido e vivo e caráter semelhante à marcha, que se dança em pares. Diccionario Manual de la Lengua Española Vox. (C) 2007 Larousse Editorial, S.L. Disponível em: <http://74.125.47.132/search?q=cache:pAd46Kydd_YJ:es.thefreedictionary.com/pasodoble+pasodoble+conce pto\&cd=2\&hl=pt-BR\&ct=clnk\&gl=es> Acesso em: 20 jul.09.
} 
Nesse documento, a equipe dispunha de informações acerca das relações estabelecidas entre os personagens e eu. No perfil estavam minhas percepções acerca da cultura subjetiva de cada entrevistado, a descrição dos ambientes de convivência em suas residências, lugares onde preferia passar a maior parte do tempo, quais os objetos biográficos e outros objetos de estimação que eram importantes como fotos, livros, símbolos culturais etc.

Com esse refinamento de informações, era elaborada uma "ordem do dia" para a gravação de cada entrevistado, que servia de base para o trabalho de toda a equipe no momento da gravação.

De acordo com a natureza da produção do documentário, que tem como princípio fundante a representação do mundo histórico, percebemos, desde o início, que a produção tem pouca margem de controle sobre o que vai ser gravado.

Por exemplo, desde o início da concepção das gravações, queríamos gravar a preparação dos personagens para registrar e revelar as diferentes performances das pessoas diante das câmeras, enfim, como elas constroem os personagens que querem mostrar para o público. Foram concebidas cenas diferentes para cada um e de acordo com suas rotinas diárias.

Entretanto, a ideia foi recusada quando apresentada a eles. Margarita Riudoms não comentou nada na pré-entrevista. Apenas notamos que ela já estava arrumada (com a roupa e maquilada) e pronta para a gravação. Carmen Baena e Mari Carmen não se sentiram à vontade para gravar tais cenas. Mari Carmen expressa sua percepção na entrevista acerca dessa proposta. Segundo ela, gravar cenas fazendo suas unhas, mostrando as roupas e se maquilando lhe pareceu uma situação muito distante e artificial; não fazem parte de seu cotidiano e não representam sua personalidade. Ela comenta na entrevista gravada: 


\section{Fita Espanhóis nำ1}

13'05" a 13'39" - Porque soy uma persona un poquitín... tengo ciertas manias como todos los viejos que pasan de los 50 acumulas uma série de manias... y uma de las manias que yo tengo es justamente esa: que no me gusta ostentar aquello que yo no soy! Me parece arrogância! Yo soy así: soy uma persona simples, no simplória! Simples! És diferente! Simplória no lo soy! Muchos Le puedo dar esta impresion pero no lo soy! Me hago La tonta porque me conviene! (Um documentário de afeto: espanhóis na cidade de São Paulo. Direção: Isabel Blanco. Ano produção 2009).

Conseguimos, no entanto, gravar essas cenas de construção do personagem com José Luis Blanco. Não foram as cenas concebidas na ordem do dia, mas as cenas necessárias ao momento da gravação. Enquanto PC Toledo estava montando o set e abriu a câmera para fazer teste de iluminação com o entrevistado, percebi que ele vestia uma camisa de listras azul-marinho com fundo branco. Perguntei ao diretor se a camisa dava "batimento" no monitor. Ele afirmou que sim e precisaríamos trocar. Toda essa sequência foi gravada com a câmera HD fixa e com a câmera móvel até o entrevistado se levantar da poltrona, set da entrevista.

Quando José Luis sai da sala e vai ao seu quarto escolher outra camisa comigo, Vanderley o acompanha com a câmera móvel. A partir daí, ele interage com a câmera durante o tempo em que dura essa ação: pega as camisas no cabide, escolhe comigo, mostro para PC Toledo, ele veste a camisa. Enquanto se veste, olha para câmera e sorri, passando a mão no cabelo para ajeitá-lo. Depois menciona Humphrey Bogart em uma cena com Ingrid Bergman no filme Casablanca. Essa menção nos faz deduzir que ele estava se sentindo como um astro de cinema.

Pudemos gravar outros momentos descontraídos dele quando pensava que não estávamos gravando. Ele mostra-se mais relaxado na maneira de falar. Sua voz assume um tom de conversa informal, diferente do tom durante a maior parte do tempo da entrevista. Nos momentos em que ele está imbuído de seu personagem, 
sua fala assume um ritmo pausado, explicativo, didático. Perde sua espontaneidade, bem diferente dos momentos de conversa gravados com a câmera móvel.

Descreverei e refletirei separadamente sobre experiência do encontro e do embate na gravação de cada entrevistado. Julguei necessário refletir individualmente porque constatei que as situações foram completamente diversas com cada entrevistado.

\subsubsection{Gravação das entrevistas}

Optei por refletir separadamente sobre o método de gravação das quatro entrevistas porque constatei que havia mais particularidades do que semelhanças entre elas. Elaborar uma reflexão com todas as entrevistas juntas significaria homogeneizar o processo.

Entretanto, há algumas características gerais a serem analisadas. Na minha relação de embate com o tema, esse procedimento de produção é considerado como o momento mais significativo de meus embates pessoais. Desde a chegada nas residências, a recepção à equipe, as reações de expectativa e ansiedade dos entrevistados no momento da gravação pairavam no ar. Esses sentimentos e sensações me contagiavam, mas eram equilibrados pela necessidade e curiosidade de saber o que o "mundo histórico" me revelava nessas circunstâncias. Na postura de diretora, colocava-me de forma receptiva ao ambiente, no sentido de apreender o que estava acontecendo à minha volta.

A abertura que o documentarista precisa ter no embate com o real é tema contemplado nas reuniões no grupo Aruanda lab.doc. Nas discussões, menciona-se a necessidade de o documentarista estar atento ao que o real lhe revela para poder 
captar esses momentos com a câmera. Colocava-me na postura de uma aprendiz de documentarista e de diretora.

Outro aspecto comum a todas as gravações, que merece destaque, é a postura ética e humanizada da equipe na relação com os entrevistados antes e durante as gravações. Assumiam a atitude de uma recepção atenta, delicada, acolhedora e sensível aos relatos narrados e compartilhados.

Esse fator deve-se ao senso ético (humano e profissional) por parte de todos, que existiu não só com os entrevistados, mas também da equipe em relação a mim nas discussões das reuniões quando relatava sobre meus embates pessoais envolvidos no processo.

Quando estávamos gravando, pedia aos entrevistados para que nos contassem trechos de suas histórias de vida. Não era apenas para mim que eles contavam. Mas para todos da equipe! Todos se tornaram ouvintes atentos de suas histórias. Essa característica possibilitou o caráter inédito dos relatos; inclusive, em vários momentos, o entrevistado assumia em sua fala que contava a todos: "Vou contar esta história para vocês". Assim, desfrutávamos do frescor do relato sendo narrado pela primeira vez para todos e que fora contado anteriormente para mim na pesquisa de personagens.

Outra característica importante trabalhada por mim, na direção de todos os entrevistados, foi o tom de confiança, intimidade e afetividade nas entrevistas, fruto das relações e vínculos construídos durante longo período de conhecimento e amizade entre os entrevistados e eu. Esses componentes se constituíram no substrato para plasmar tal relação dos entrevistados comigo e, posteriormente, com a equipe. Estou segura de que, sem esses componentes, muitos conteúdos não teriam sido revelados. 
Acrescentaria que a confiança e a intimidade assumem dois aspectos: no âmbito pessoal e profissional. Todos os entrevistados percebiam o cuidado (técnico e psicológico) que tivemos ao lidar com eles durante as gravações. Esses aspectos serão discutidos separadamente em cada entrevista.

Eles também estavam cientes de nossa postura ética no que diz respeito à publicação de seus relatos. Utilizaremos a estratégia de Eduardo Coutinho na sua relação com os entrevistados. Quando o documentário estiver finalizado, haverá uma exibição, em circuito fechado, para eles, a fim de discutirmos se a maneira como estão representados não lhes trarão repercussões negativas.

As reflexões sobre cada entrevista foram elaboradas a partir de duas vertentes: encontros e embates da diretora com os entrevistados. Classifiquei os embates como profissionais e pessoais. Por meio de tais perspectivas, se refleti acerca da ética estabelecida entre os entrevistados e a direção.

Também foram descritas as cenas das construções dos personagens a fim de se refletir acerca das performances dos entrevistados na interação com a câmera e de que forma eles se construíram como personagens, bem como foram construídos por mim.

A proposta estética para as gravações foi assim concebida: gravação com duas câmeras; a primeira câmera com a fotografia principal (HD) fixa e captação de áudio com microfone direcional. A segunda, auxiliar (Mini-DV), fixa no mono pé como opção para corte e dinamização na edição da entrevista. Para esta câmera, previase uma linguagem com planos fechados e closes dos entrevistados.

As sequências denominadas "memória afetiva" e "objetos biográficos" seriam captadas pela câmera móvel (Mini-DV), bem como imagens de cobertura de 
símbolos culturais, fotos sendo mostradas pelos entrevistados, entre outras situações.

\subsubsection{Primeira gravação - Mari Carmen Acirón Rius}

\section{Relação da equipe com a entrevistada}

Essa foi a primeira entrevista gravada. De acordo com o planejamento da produção, não queríamos começar as gravações com Mari Carmen, pois ela era a pessoa que mais sabia sobre o projeto.

Queríamos iniciar o processo com alguém que não dominasse tanto 0 assunto, porque a primeira gravação serve como experiência e teste inicial para a equipe, no sentido de testar os equipamentos, a linguagem, a relação entre os profissionais, na equipe, e entre a equipe e os personagens.

Mas infelizmente não havia outro entrevistado preparado para gravar naquele dia. Já vínhamos adiando o início da gravação e, por esse motivo, não quisemos protelar mais. A equipe priorizou os dias de sábado para as gravações devido aos horários de trabalho dos profissionais.

Chegamos à sua residência antes do horário previsto. Carmen não conhecia a equipe. Acolheu-nos muito bem, como boa anfitriã que é, e nos ofereceu almoço após a gravação. Sentimo-nos como amigos da família.

Desde aquele dia, percebemos o traço integrador das culturas por meio da culinária: seu cardápio era feijoada com tortilla de batata e, de sobremesa, um doce português - ambrosia. O almoço não foi gravado. Apenas gravamos (com a câmera móvel) a preparação do almoço na cozinha. 
A equipe, desde o início das gravações, teve uma atitude cuidadosa, pois estávamos entrando nos ambientes privados e íntimos das pessoas, suas residências. No caso da montagem do set de gravação para Carmen, o cinegrafista, PC Toledo, sentiu necessidade de tirar alguns móveis da sala para liberar espaço para sentarmos, mudar a mesa da cozinha de posição e tirar as cadeiras. Ou seja, o set ocuparia o espaço da sala e da cozinha (como fundo do plano).

Em cada mudança, avisávamos Carmen com antecedência, explicávamos e solicitávamos autorização para fazê-la, pois sabíamos que estávamos transformando completamente a configuração de seu ambiente doméstico. Sempre ressaltava a ela que, ao terminarmos, deixaríamos o ambiente tal como encontramos. Mas todo esse procedimento e cuidado não impediu que ela demonstrasse, muitas vezes, seu receio em quebrarmos algo ou de que seu marido chegasse, visse e reclamasse com ela.

\section{Construção da personagem}

Para a gravação das cenas de construção da personagem, propus a Carmen que a gravássemos se maquilando, mostrando suas roupas e fazendo as unhas. Ela não gostou da ideia, mas não discutimos sobre isso durante a pesquisa de personagens. Quando chegamos à sua residência, ela já estava pronta: maquilada, penteada, com as unhas feitas. No início da gravação, quis trazer essa discussão para o documentário e perguntei-lhe por que não gravou as cenas de construção da personagem. Ela explicou que essas cenas pareceriam estranhas a ela, que é uma pessoa simples. 
Mas há outros momentos em que ela inesperadamente brinca com a construção da personagem captada pela câmera móvel.

Enquanto Fabiana estava gravando a ação de montagem do set de gravação, a câmera surpreende em close no rosto do diretor, PC Toledo, que olha para câmera e diz: eu não sou o personagem!

Imediatamente após essa fala, Carmen, que está ao lado, chama a atenção da câmera para si e fala:

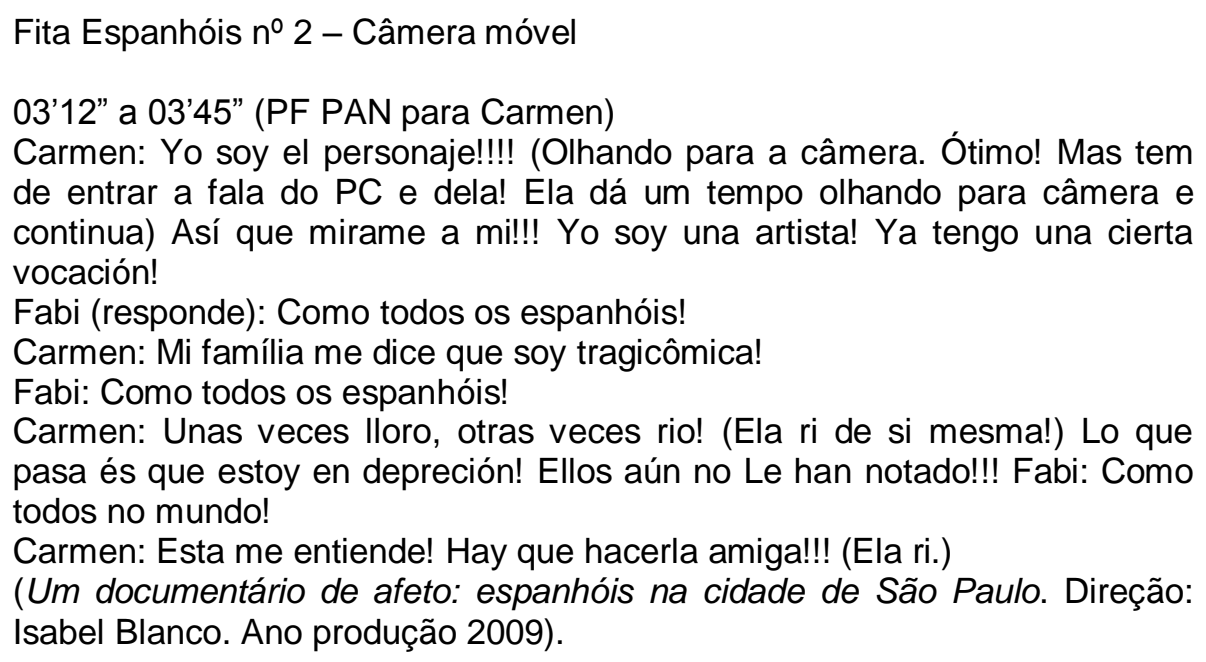
de entrar a fala do PC e dela! Ela dá um tempo olhando para câmera e continua) Así que mirame a mi!!! Yo soy una artista! Ya tengo una cierta vocación!

Fabi (responde): Como todos os espanhóis!

Carmen: Mi família me dice que soy tragicômica!

Fabi: Como todos os espanhóis!

Carmen: Unas veces lloro, otras veces rio! (Ela ri de si mesma!) Lo que pasa és que estoy en depreción! Ellos aún no Le han notado!!! Fabi: Como todos no mundo!

Carmen: Esta me entiende! Hay que hacerla amiga!!! (Ela ri.)

(Um documentário de afeto: espanhóis na cidade de São Paulo. Direção: Isabel Blanco. Ano produção 2009).

Percebi que ela gostou dessa "brincadeira". Em vários momentos da entrevista, ela comentava ironicamente sobre as sensações que tinha representando aquela personagem: sentia-se uma atriz, segundo ela, uma artista!

\section{Embates profissionais}

Nessa gravação, a amizade com Carmen, em grande medida, foi elemento que me inibiu e limitou-me para o desempenho da função de diretora. Tinha pouco poder de decisão, estava insegura e não me impus perante a entrevistada para dirigi-la. Na semana seguinte, avaliamos a gravação na reunião de equipe e discutimos sobre isso. Fabiana enriqueceu minha avaliação, que tornou mais 
consciente e lúcida a debilidade na minha atuação. Serviu para aprender a me posicionar mais como diretora nas gravações seguintes.

Minha postura de diretora na gravação também deixou a desejar no sentido de planejar e decupar os ambientes a serem gravados. Pois deveria ter elaborado, juntamente com a produtora, que estava operando a câmera móvel nessa gravação, um documento de produção, uma lista de todos os planos e dos lugares que deveriam ser gravados com aquela câmera. Ficaram faltando mais planos fechados em panorâmicas (subjetivos) de toda a decoração da cozinha de Carmen e faltaram mais planos da decoração e dos símbolos culturais da sala. Mas não tivera esse hábito de sistematizar e elaborar um documento dessa natureza em nenhuma experiência profissional anterior.

\section{Embates pessoais}

Posso afirmar que não senti embates desafiadores nessa gravação. Conhecia muito da história de vida de Carmen, de todas as vezes que ela me contava e recontava seus episódios. A amizade e os vínculos construídos entre Carmen e eu possibilitaram-me compreender a cultura e comportamento espanhóis e sua interrelação com a cultura brasileira.

As informações colhidas a partir do questionário de pré-entrevista foram relatadas e gravadas. Houve poucas informações novas durante a gravação.

Mas o fato de Carmen narrar suas histórias na presença da câmera e mostrando a personagem construída assumia aspectos diferentes. Seu modo de narrar adquiriu mais dramaticidade e encenação, além da nitidez de seu estado de 
nervosismo. Isso a levou a lapsos de memória em alguns momentos, conforme explicou a mim após a gravação.

Ela esqueceu-se de trechos de músicas que cantou inúmeras vezes para mim. O mesmo aconteceu ao tentar declamar o poema de Garcia Lorca que tinha de cor e de que tanto gostava. Fez um esforço de memória, que a câmera captou, mas não conseguiu se lembrar de longos trechos do poema.

Nestes momentos pude comprovar, na prática, como se opera o trabalho da memória descrito por Bosi.

Ouvindo depoimentos orais constatamos que o sujeito mnemônico não lembra uma ou outra imagem. Ele evoca, dá voz, faz falar, diz de novo o conteúdo de suas vivências. Enquanto evoca ele está vivendo atualmente e com uma intensidade nova a sua experiência. (BOSI, 2003, p. 44).

Portanto, se o trabalho da memória se dá por meio de evocação, Meihy (2002) nos alerta que há uma relação direta entre memória e esquecimento. E ainda segundo ele, é importante observar um para entender o outro. Porque Carmen, no momento da entrevista, se esqueceu de trechos de um dos poemas de que ela mais gosta e que sabe de cor? Seria apenas o nervosismo?

\section{Encontro}

Os momentos de encontro foram construídos ao longo do processo de pesquisa de personagens e pelo relacionamento de amizade e confiança construído no nosso trabalho voluntário do Centro Valenciano. A pré-entrevista aconteceu em várias etapas. Frequentemente (todos os sábados), Carmen contava-me os episódios de sua história de vida. Essas ocasiões propiciaram-nos o conhecimento mútuo, a relação dialógica, conforme postula Meihy (2002), na relação do oralista 
(diretora) com o entrevistado. Minha postura, na maioria das vezes, era a de ouvinte atenta. E, conforme Coutinho, sem estabelecer julgamentos acerca das narrativas. Apenas ouvir as estórias e apreendê-las, com o respeito necessário para compartilhar tal relato.

Esses encontros periódicos foram preparatórios para o momento mais significativo: a gravação da entrevista. A gravação registrou o encontro de Carmen comigo, com a equipe e com a câmera. Surpreendeu-me a intimidade com que ela interagiu com nossa câmera. Em nenhum momento a incomodava, brincava com a situação da gravação e de sua personagem. Ela construiu sua personagem para interagir com essa câmera e, ao longo de seu relato, dizia como estava se sentindo.

\subsubsection{Segunda gravação - José Luis Blanco Goicoechea}

\section{Relação da equipe com o entrevistado}

Chegamos no horário marcado ao apartamento onde meu pai, José Luis, mora com minha mãe. A montagem do set de gravação aconteceu na presença dele. Enquanto isso, minha mãe terminava os preparativos para o almoço de todos.

Vanderley logo tratou de montar a câmera móvel para gravar cenas de making off da montagem do set, na sala, e dos preparativos do almoço, na cozinha. Sua estratégia era interagir por meio de conversa amistosa e próxima com as pessoas que estavam sendo gravadas. Isso possibilitou um diálogo do entrevistado com ele e com a câmera móvel.

$\mathrm{Na}$ etapa da pesquisa de personagem, não falei para meu pai como seria o estilo de documentário que estávamos produzindo. Achei melhor comentar alguns 
detalhes no dia da gravação a fim de não causar ansiedade. Enquanto Vanderley gravava e PC Toledo montava o set de gravação, conversei com meu pai na sala. Apenas disse a ele que pretendíamos produzir um documentário que tivesse os espanhóis como protagonistas de parte de suas histórias de vida. Ele ouviu atentamente e acrescentou jocosamente que depois poderíamos enviar ao History Channel para exibição. Vanderley gravou essa sequência.

Expliquei-Ihe que a maneira como representaria esses imigrantes seria de forma humanista, atribuindo-lhes status de pessoas honestas e dignas, que construíram suas vidas no Brasil. Representação muito diferente do que se instituiu no imaginário de muitos espanhóis que emigraram do país, pois, à época dos fluxos emigratórios, segundo Corner, o governo espanhol adotou a postura de que os emigrantes eram traidores da Pátria, desertores, indignos e indicadores da pobreza do país. (CORNER, 2000, p. 06).

Como conheço seu temperamento genioso, tinha receio de que ele não gostasse dos profissionais e chegasse a ser grosseiro ou os maltratasse. Mas quando percebi que simpatizou com eles, tranqüilizei-me.

Em vários momentos da montagem do equipamento e do set de gravação, José Luis interagia com os dois profissionais, fazendo alguma piada. Pareceu-me que estava curioso com aquele processo e talvez nervoso.

\section{Construção do personagem}

A construção do personagem foi surpreendente, pois ele se dispôs a gravar todos os momentos dessa construção. Quando fizemos o teste de iluminação com a câmera, constatamos que a camisa listrada dava "batimentos" no monitor. Portanto a 
câmera móvel de Vanderley nos acompanhou da ida ao quarto para escolha e troca de camisa até a volta ao set de gravação na poltrona da sala.

Houve um momento bem simpático enquanto trocava de camisa. Ele olhou para a câmera e interagiu com ela. Sorriu e passou a mão no cabelo, ajeitando-o como os galãs de filmes clássicos do cinema. Mencionou Bogart em uma conversa comigo e, nessa referência, demonstrou que se sentia como galã de cinema.

\section{Embates profissionais}

No dia da gravação, comecei a pensar em todos os componentes que estavam "em jogo" na situação com meu pai.

Era a primeira vez que lidava com ele no âmbito profissional. Veio-me à mente tudo o que ele sempre me disse a respeito de como teria de ser nosso (dos filhos) desempenho profissional. Segundo ele, sempre que nos dispuséssemos a fazer algo, deveria ser bem feito. O grau de exigência dele era alto e a exigência para comigo mesma acabou se tornando alta também. Aquela seria a primeira vez em que ele me veria atuando profissionalmente. Estava bem nervosa.

Era a segunda entrevista, então estava mais segura sobre a atuação como diretora. Felizmente a gravação foi tranquila e reveladora. Todas as solicitações de direção que fiz foram atendidas por ele. Estava bem-humorado e descontraído naquele dia. Isso facilitou muito nosso trabalho. 


\section{Embates pessoais}

Todas as questões envolvidas neste projeto têm a ver com a nossa relação de pai e filha. O momento da gravação seria o ambiente dos embates e, talvez, de revelações; o cenário onde poderiam vir à tona questões interiores dele e minhas. Como ele iria reagir às minhas orientações de direção, considerando seu temperamento explosivo e a relação de poder hierárquica de pai e filha? E como eu lidaria com suas resistências? Ele iria concordar em gravarmos cenas da construção do personagem? Previa que não, pois a flexibilidade não é o seu forte.

\section{O foco da entrevista (e da minha busca): as identidades culturais}

Ele sempre disse que era espanhol até a medula! E que nós éramos brasileiras. A maneira como essa informação foi apreendida e interpretada por mim gerou um bloqueio com a cultura espanhola, conforme comentado anteriormente no Capítulo 2. Ou seja, ele nunca havia comentado ou admitido seu processo de aculturação no Brasil.

Quando perguntei sobre a construção de sua identidade cultura, fiquei surpresa, pois, naquele momento, diante das câmeras, ele afirmou que depois de tantos anos morando no Brasil havia absorvido características dessa cultura e se considerava parcialmente brasileiro, conforme trecho transcrito da gravação:

Fita Espanhóis no 7 - Câmera fixa

55'28" a 56'19" (José Luis) - Me siento muy madrileño. Pero, reconozco que soy más brasileño que español. Es así, es la realidad de la vida. Yo casi, casi... cuando fui hace doce o quince años fui a Madrid. Los colegas allí, que tengo... aun tengo algunos... me decían "Tu hablas... hablas igual que lo portugués. Parece portugués. Parece gallego. Parece gallego". Que el gallego es un poco "aportuguesado". Y como en Brasil se habla portugués, pues ellos juzgan que nosotros aquí nos parecemos con los gallegos 
cuando hablan allí. Pero, en general, estoy contente con lo que he conseguido aquí. Pero, añoro, "sinto saudades" de lo que yo tenía allí. (Um documentário de afeto: espanhóis na cidade de São Paulo. Direção: Isabel Blanco. Ano produção 2009).

Esse foi um momento de surpresa e revelação que o documentário nos proporcionou. Imediatamente após essa revelação, pensei em perguntar-Ihe por que afirmara sua indentidade brasileira naquele momento, se nunca havia admitido seu processo de aculturação brasileira anteriormente. Mas não quis expor em público esse questionamento tão íntimo, delicado e importante para mim. Nem expô-lo em tal situação pública.

Achei melhor conversar com ele sobre esse assunto posteriormente e em ambiente privado, mas me questionei por não ter feito a pergunta durante a gravação. Senti que perdi momento importante de ser registrado. No embate entre a postura de diretora/documentarista e de filha, a postura ética de filha prevaleceu.

Questionei-me a respeito dos motivos pelos quais ele teria feito essa afirmação. Faria parte de seu personagem? Seria esse o discurso que ele achou que as pessoas precisariam ouvir. Ou queriam ouvir? Ou será que, desde que fiz a entrevista na pesquisa de personagem, ele vem se questionando também sobre o tema? Estas questões somente ele pode responder. Conversarei com ele sobre este assunto.

\section{Apoio da equipe no embate com o personagem}

Toda a ansiedade e nervosismo que senti tiveram seu equilíbrio nas atitudes da equipe para lidar com a situação. Naquele dia, estavam Vanderley e PC Toledo. 
A produtora Fabiana Sanches não pôde ir.A tranquilidade e a delicadeza deles harmonizou o ambiente e forneceu o equilíbrio e confiança de que necessitava.

Aliás, em todos os momentos da produção senti, da equipe, apoio e amparo às minhas questões pessoais. Eles foram o sustentáculo necessário para vivenciar essa situação. A sensibilidade, ética e compreensão humanas deles possibilitaramme estabelecer a confiança a e coragem de que necessitava para esta "caminhada".

Um aspecto peculiar dessa gravação e, mais uma vez inesperado para mim, foi a atitude de minha mãe, dona Cidinha, diante da situação. Desde o início, ela chamou a atenção da câmera móvel para aparecer no documentário. Ela reivindicava sua participação na construção daquele personagem, na representação da vida de meu pai. Então gravamos as cenas das situações nas quais ela estava envolvida: desde à preparação do almoço, na explicação da receita e no modo de preparo da tortilla (omelete de batatas) até a mesa do almoço e os relatos de suas viagens à Espanha.

Depois do almoço, tivemos uma conversa descontraída à mesa. PC Toledo entrevistou José Luis e o gravou com a câmera móvel. Perguntou sobre assuntos mais amenos, como futebol, os palavrões em espanhol, sobre as viagens à Espanha etc. Também tiveram a oportunidade de conversar sobre assuntos que ele havia mencionado na entrevista, mas, dessa vez, de forma mais descontraída em tom de conversa informal. Houve alguns momentos em que ele perguntou ao PC Toledo se ainda estava gravando.

Essa sequência gravada foi longa e rica porque ele estava mais descontraído do que na gravação de entrevista. Pode ser editado com trechos da entrevista gravada com a câmera fixa e com a câmera móvel. Na edição, ficarão explícitas as 
duas performances: a dele como personagem mais sério, duro e uma atuação mais simpática e descontraída.

\section{Encontro}

O encontro a se destacar nesta gravação aconteceu pela minha surpresa na interação com o personagem construído por meu pai desde nossa chegada. Ele fez questão de revelar um personagem simpático e bem-humorado diante das câmeras. Uma faceta sua não muito presente no cotidiano, mas que gerou a empatia por parte dos profissionais da equipe e, provavelmente, por parte do público que assistirá ao documentário.

O cuidado intimista, conforme Meihy (2002) menciona, na relação do entrevistado comigo e com a equipe, principalmente nos momentos da gravação em que ele narrou seus traumas e dores, foram importantes e decisivos para a continuação da entrevista. Nesses momentos de choro, de emoção mais intensa, ele chegou a mencionar de parar a gravação por estar muito emocionado. Minha postura foi de respeito e espera, a paciência devocional a que se refere Meihy (2002), prevaleceu até ele se recompor.

No final do segundo momento da entrevista, com a gravação de PC Toledo operando a câmera móvel, ele afirmou que já estava cansado e sorriu para nós e para a câmera dizendo algo como: "He disfrutado de estes momentos!". Esta afirmação caracterizou para mim o momento da consagração da entrevista. Além de valorizar nosso trabalho no desempenho das funções e no relacionamento com o entrevistado, o encontro! Por essa cena, e pelas outras gravadas, o filme "aconteceu", conforme afirma Coutinho (2005). 


\subsubsection{Terceira gravação - Margarita Riudoms Fernandez}

\section{Relação da equipe com a entrevistada}

Margarita é minha tia e optei por gravar com ela porque sempre conversamos sobre questões de relevância no que diz respeito às identidades culturais; além disso, ela tem uma história de vida rica e é uma boa narradora. Certamente, ela seria um personagem rico para se gravar.

Chegamos à sua residência com certo atraso. Avisei do atraso à entrevistada. Quando chegamos, notei que ela estava nervosa e ansiosa.

Ela foi a única entrevistada que nos recebeu com o ambiente preparado à moda espanhola: as músicas espanholas que sua família ouvia estavam tocando, ela já havia preparado os pães com tomate e jamón (presunto de parma), típicos da Catalunha, para tomarmos um lanche típico catalão após a gravação. No quarto de hóspedes, ela havia separado os discos e livros para pesquisa do diretor musical.

Valemo-nos do aprendizado construído nas gravações anteriores para lidar com os entrevistados. A equipe trabalhou silenciosa e delicadamente para trazer o equipamento. PC Toledo e eu vimos os ambientes e gostamos do terraço que havia após a cozinha. Pensamos em gravar a entrevista em ambiente externo, para diferenciar das outras entrevistas. Pedimos à Margarita que se sentasse na cadeira enquanto a montagem do set de gravação acontecia para que ela acompanhasse o processo e se sentisse mais à vontade.

Ela observava atentamente o trabalho da equipe. Fábio Cintra, diretor musical, tinha em mãos alguns discos e conversava com ela sobre as músicas. 
Vanderley estava gravando com a câmera móvel. Juntei-me à conversa e sentei-me ao lado da câmera fixa. PC Toledo já havia montado câmera e microfone e acionou, discretamente, o play. Isso possibilitou o registro dessa conversa e uma performance descontraída de Margarita. Era o tom de conversa. Ela nos contava sobre um passeio em que foi assistir à apresentação de um grupo de teatro popular. Ela riu em vários momentos, alterou o tom de voz várias vezes e falava à vontade, sem se preocupar em qual idioma se expressava. Performance bem diferente - uma outra face, diria -da personagem construída por ela no momento da entrevista.

Era um dia ensolarado, mas com nuvens e vento. Portanto, logo no início da gravação, PC Toledo constatou o problema de oscilação da luz solar no monitor. Avisou-me e constatamos, no monitor, que a oscilação e o contraste de iluminação eram intensos a ponto de não podermos gravar naquele lugar. Ao avisar Margarita que teríamos de mudar para um ambiente interno, ela se inquietou ainda mais.

Nossa reação foi lidar com a situação para tranquilizá-la e agilizar o processo para o novo início da gravação. Sugerimos que ela fosse até o quarto de hóspedes, com Fábio e comigo, a fim de nos mostrar seus discos e livros.

Vanderley gravou esses momentos em que ela nos mostrava os materiais no quarto. Parecia que a câmera móvel não a incomodava. Nessas sequências, ela pôde conversar conosco, mostrar os discos e livros e comentar sobre eles. Seu tom era mais íntimo, próximo, descontraído e amistoso. Senti que compartilhávamos com ela de seu passado. Aquela era a sequência "memória afetiva" que pretendíamos captar.

Enquanto estávamos vendo os discos e livros, o segundo set de gravação foi montado na sala de estar. Antes de alterar a configuração do ambiente, pedimos autorização a ela. Mas como ela não estava presente para participar e ver as 
mudanças da mobília (afastamos a mesa da sala de jantar, tiramos as cadeiras, afastamos os sofás e tiramos a mesa de centro), quando ela chegou, o set estava pronto e sua sala totalmente modificada! Sua reação foi instintiva. Ela estranhou aquele lugar e deve ter sentido que aquele não era seu ambiente.

Na reunião da equipe, na semana seguinte à gravação, discutimos sobre essa reação dela. Fábio Cintra foi perspicaz em sua explicação: nós nos apropriamos de seu espaço, de seu ambiente privado.

O estranhamento dela contribuiu, em grande medida, para sua performance na gravação da entrevista. Sentada ao sofá, pareceu-me constrangida. Seu corpo estava encolhido; suas mãos no colo, sem se mover, como de costume. Ela estava com as pernas encolhidas e não me parecia nada à vontade. Seu corpo estava contido diante das luzes, da câmera e da situação. Pareceu-me a atitude de quem estava "na berlinda". Assim ela permaneceu durante toda a entrevista, que durou apenas trinta e oito minutos. Suas respostas eram monossilábicas. Outras vezes, frases curtas e risos nervosos respondiam às perguntas.

\section{Construção da personagem}

Pude notar sua construção do personagem pela maquilagem, pelo penteado e pelo figurino escolhido por ela. Estava com um vestido colorido. Pareceu-me estranho, pois não costumo vê-la de vestido.

A sua construção do personagem continuou no início da gravação. Na postura comedida de sentar, com as mãos no colo, e parecia muito tensa. Essa era a primeira vez em que via minha tia constrangida, calada e sisuda. Durante a 
gravação, respondeu com monossílabos. Várias respostas demonstravam sua contrariedade ao falar sobre alguns assuntos.

\section{Embates profissionais}

Minha tia Margarita tem uma participação expressiva em minha educação. Também senti o peso de ter de trabalhar e mostrar a ela meu desempenho profissional. E, desde nossa chegada, ela percebeu qual era nosso empenho e profissionalismo.

Logo que começamos a descarregar o equipamento, Vanderley montou a câmera móvel e acompanhou Margarita nos recebendo e entrando na casa. Sua expressão de surpresa era nítida ao ver todos os equipamentos e a equipe

Fita Espanhóis № 11 - Câmera móvel

00'16" a 00'43" (Margarita) - (olha para a câmera) O negócio é muito sério... (para e ri)... eu pensé que o negócio era brincadeira! (vira as costas e entra na sala). (Um documentário de afeto: espanhóis na cidade de São Paulo. Direção: Isabel Blanco. Ano produção 2009.)

\section{Embates pessoais}

Essa gravação foi bem difícil para eu lidar, pois, durante a entrevista, surgiram várias situações de embates pessoais e questionamentos éticos. Percebi que, à medida que fazia mais uma pergunta, tocava em feridas psicológicas que para ela eram difíceis de serem tocadas e expostas. A situação tornava-se cada vez mais tensa. E, no meio da entrevista, comecei a me questionar se tinha o direito de tocar em suas dores. Tive uma crise ético-psicológica. Essas inquietações foram tão fortes, que todos perceberam durante a gravação, mas nada se comentou. 
Outro aspecto que serviu de agravante da situação foi a relação assimétrica de poder que se estabeleceu na entrevista. E percebi: eu não era aquela sobrinha que esteve lidando com a tia por meio dessa relação, mas sim uma mulher, profissional, entrevistadora, em busca de respostas existenciais minhas e que tinham a ver com as questões existenciais dela. Questões essas que se constituíam em aspectos psicológicos traumáticos. Devo dizer que não tinha consciência da intensidade dessa situação interior para ela. Se soubesse antes, talvez não a tivesse entrevistado.

Diante de tais embates, a questão ética, profissional e humana prevalecia, pois me continha nos momentos de formular as perguntas.

Os momentos considerados mais críticos por mim foram quando perguntei sobre seu primeiro marido e sobre meu tio, seu segundo marido. Sempre tive uma relação de afeto por ele.

Suas respostas foram distantes e ela não nomeou os dois maridos. Eles não tinham nomes, nem características, nem personalidades naqueles relatos, conforme trecho transcrito:

\footnotetext{
Fita Espanhóis ํo 12 - Câmera fixa

27 '54" a $28{ }^{\prime} 07^{\prime \prime}$

27’54" (Bel) - ¿Y... después te casaste con un español, con un brasileño, después...?

28'01" (Margarita) - Con un español.

28'03" (Bel) - ¿Y cuanto tiempo estuviste casada con él?

28'06" (Margarita) - Veinte años. (Um documentário de afeto: espanhóis na cidade de São Paulo. Direção: Isabel Blanco. Ano produção 2009.)
}

Os questionamentos éticos ressoaram em mim a ponto de, no dia seguinte, refletir sobre tudo o que aconteceu. No início da semana seguinte à gravação, liguei para uma colega de trabalho, a psicanalista Fernanda Colonnese, e contei-Ihe sobre 
o ocorrido e o quanto estava angustiada e preocupada. Marcamos um conversa um dia depois e foi esclarecedor.

Relatei à Fernanda Colonnese o ocorrido e ainda me perguntava se tinha o direito de que meus questionamentos existenciais fossem expressos e expostos em um documentário, portanto, sujeitos à publicação, por meio das entrevistas das pessoas. Fernanda me tranquilizou, perguntando se Margarita havia sido coagida a gravar. Disse que apenas fizera um convite e ela aceitou gravar. Portanto, eu não estava sendo antiética com ela, uma vez que concordou com a gravação da entrevista.

Fernanda acrescentou uma observação com relação aos silêncios, aos momentos em que ela estava contida, aos não-ditos. Essas situações são reveladas pela exposição pública (set de gravação) e será preciso construir isso na edição.

Depois da conversa me senti mais tranquila e menos culpada, sem ter ultrapassado os limites da ética humana nas minhas curiosidades e inquietações expressas no documentário.

Apesar da economia das palavras, durante a entrevista houve revelações sobre sua história de vida. Contou suas primeiras emoções no momento da chegada ao Brasil. Declarou que não queria sair da Espanha; chegando aqui, seu esposo voltou para a Espanha e ela, mesmo não gostando do país, não voltou.

Em minha opinião, um dos aspectos mais relevantes de sua entrevista foi sua reflexão sobre a construção de sua identidade cultural. Ela atribuiu à dimensão humana da questão, conforme transcrição: 
Fita Espanhóis ํo 12 - Câmera fixa

30'32" a 31'04" (Margarita) - No, no precisa. Ser espa... ser catalana, ser española... ser "brasileira", casi "tudo" es igual. "O" que importa es lo que "você" es. Lo que "você" es como ser humano, como persona y "o" que "você" cultivó de todos los lugares que vivió. Si "você" cultivó la parte "boa"... yo soy catalana, española y "brasileira", porque cultivé un poco de "bom" de cada. (Um documentário de afeto: espanhóis na cidade de São Paulo. Direção: Isabel Blanco. Ano produção 2009.)

O fato de seu ponto de vista extrapolar os limites nacionais ou regionais da questão e atribuir a dimensão humana a ela foi revelador para mim e apaziguador da questão na busca e embates sobre a minha identidade.

\section{Encontro}

O encontro dessa gravação se expressou, em boa medida, por meio dos relatos inéditos (para mim) acerca de episódios da vida de Margarita. O momento mais significativo desse encontro foi a atitude de Margarita na cozinha, após a entrevista com a câmera fixa, quando ela nos convida para tomar um lanche com ela.

Essa situação, gravada com a câmera móvel, não se configurava na estrutura rígida anterior da entrevista nem estava prevista para gravação, mas sim em uma situação de conversa informal com a equipe à mesa. Nessa ocasião, ela narrou situações que não havia mencionado na gravação anterior. Essa performance dela, mais descontraída, dizia a mim que era daquela maneira que ela preferiria ser representada, com que se identificava mais. Naquela situação, percebi o encontro dela comigo (diretora). Cheguei a pensar na possibilidade de ter gravado toda a entrevista na cozinha, à mesa. Entretanto, essa possibilidade aconteceu no final da 
gravação. Não conseguiríamos gravar toda a entrevista novamente porque ela estava cansada e respondeu que não queria repetir a gravação.

De qualquer forma, na construção do personagem, no processo da edição, teremos várias performances: a conversa inicial no terraço, na sala - sentada no sofá -, na sequência da memória afetiva, quando mostra seus livros e discos e, finalmente, na cozinha com a equipe. Ou seja, um encontro que nos ofereceu várias possibilidades para a construção do personagem. Conforme postula Coutinho (2005), os aspectos ficcionais são mais reveladores do personagem do que a pretensa adequação ao que a pessoa é "de verdade".

\subsubsection{Quarta gravação - Carmen Baena Fernandez}

\section{Relação da equipe com a entrevistada}

Minha postura de diretora foi mais tranquila e confiante, devido ao aprendizado construído das três gravações anteriores. Essa foi a última entrevista dessa etapa do processo de produção. Outro fator decisivo para eu me sentir confiante foram as características de personalidade de Carmen Baena. Ela é uma pessoa serena e emanou essa serenidade para todos nós. Sem dúvida, foi gravação em que me senti mais tranquila e confiante.

Ela nos recebeu com amabilidade, simpatia, acolhimento e carinho. Comentou, no final da gravação, que gostou muito da equipe, que éramos "quietinhos". Gravamos esta declaração.

Tivemos um cuidado humano e compromisso ético com ela, pois não havia participado de nenhuma gravação. Adotamos uma estratégia nova, sugerida pelo 
diretor, para montarmos o set de gravação. Essa ideia surgiu a partir do aprendizado, discussão e avaliação em reunião, da experiência da gravação anterior com a Margarita.

Achamos que Carmen Baena se sentiria inserida no ambiente do set se ela estivesse conosco no lugar escolhido, acompanhando a montagem e recebendo explicações do processo. Foi uma experiência gratificante e está registrada.

Tivemos de mudar todos os móveis de sua sala. Tirar a mesa de centro com os enfeites de vidro, mudar as posições dos sofás e colocar uma cadeira no canto da sala. Todo o processo foi explicado para ela e sua autorização prévia solicitada. Lembrei-a de que, depois de tudo terminado, colocaríamos os móveis no lugar em que que estavam. Quando fizemos isso, ela brincou que estava adorando e que nos chamaria nos dias de faxina.

Ela observava atentamente cada movimento dos profissionais. Quando o set estava quase pronto, afirmou: "Entendi o que vocês fizeram: transformaram minha sala em um estúdio!" Nossa reação foi instintiva e satisfatória: risos! Disse que ela tinha entendido tudo.

A grande preocupação de Carmen (durante as conversas na pesquisa de personagem) era a dificuldade que tinha de se expressar em espanhol. Dizia que misturava o português com o espanhol. Disse-lhe que não havia problema nisso. Gravamos esses diálogos, no início da entrevista, e disse que este aspecto fazia parte de sua trajetória de vida.

Conversando com Vanderley sobre nossas impressões acerca da gravação com Carmen Baena, concluímos que tivemos mais momentos de encontros, simpatias e afinidades do que de embates. Ele atribuiu isso à serenidade dela. 
Depois da gravação, ela nos ofereceu um bolo feito por ela. Ficamos conversando na cozinha. Gravamos parte dessa conversa com a câmera móvel e Carmen Baena estava bem descontraída. Revelou, espontaneamente sua explicação acerca da característica identitária do andaluz: por que nascem cantando! Contou-nos sobre os lugares que visitou na Espanha e sobre situações curiosas com as quais deparou em Sevilla.

\section{Embates pessoais}

Essa situação significou um bálsamo para minha alma. Enfim, um momento interior mais tranquilo. Sem angústias.

Concordo com Bosi (2003), que afirma que uma entrevista deve durar o tempo que dura uma amizade. Estava selada uma grande amizade entre ela e eu.

Minhas inquietações e questionamentos foram dissipados por seu espírito sábio, pacífico e sereno. Poderia continuar minha "caminhada" com o coração tranquilo!

\section{Encontro}

O processo do encontro tem sido construído desde a pesquisa de personagens, quando fiz o convite para a gravação, mas ela não concordou. Durante as negociações e diálogos, foram esclarecidas suas dúvidas e inseguranças. O momento significativo para a mudança de opinião se estabeleceu após a conversa com meus pais. Eles a tranquilizaram e comentaram como foi o processo de gravação com eles. 
Diante de sua resistência inicial, cogitava a possibilidade de não gravar sua entrevista, uma postura ética de respeito à sua vontade.

O encontro e o "falar de perto" se reforçaram quando utilizamos a estratégia de inserí-la na montagem do set de gravação. E, finalmente, durante a gravação, fomos presenteados pelos momentos inéditos de sua performance.

Dentre eles, há de se destacar o instante que ela levanta da cadeira para colocar o mantón de manilla (xale com franjas e bordados coloridos). Nesse momento, ela vê sua imagem no monitor e tem uma reação de total surpresa. Ri espontaneamente. Em seguida, pergunto a ela se gostou de sua imagem no monitor. Responde que sim e diz a mim: "te cuida, menina", sugerindo que ela, no monitor, como personagem, está mais bonita que eu.

Esses sentimentos recíprocos de diálogo, afeto e amabilidade foram constantes ao longo da gravação. Ao me despedir dela, senti um grande alívio. Aquela era a última entrevista. Comentei com o diretor musical, Fábio Cintra, que tínhamos "fechado com chave de ouro". Senti-me abençoada. Ele concordou. A serenidade e alegria de Carmen Baena pairavam sobre nós.

Acredito que a grande lição aprendida foi compartilhar sua história de vida sofrida e sacrificada. Mas apreendida do seu jeito e com seu espírito: com confiança, paz, felicidade e sabedoria para enfrentar as dificuldades e as angústias. Sentimentos estes que, segundo Bosi, se resumem em gratidão pelo que ocorreu; o ouvinte pelo que aprendeu e o narrador pelo justo orgulho de ter um passado digno de rememorar. (BOSI, 2003, p. 61). 


\subsubsection{Desenho sonoro}

A produção do desenho sonoro acontecerá a partir da entrega da dissertação e a inserção das trilhas e ruídos será feita na finalização do documentário.

Conforme proposta do diretor musical, Fábio Cintra, segue a concepção do desenho sonoro:

\subsubsection{Conceito}

A ideia central é fazer que a trilha sonora esteja integrada poeticamente (no sentido de elaboração da forma) ao discurso do filme, como parte indissociável. Deve ajudar a "levá-lo", tornando-o interessante e ágil. Ela deve também ser informativa, mas não didática. O discurso sonoro da trilha deve servir para facilitar ao espectador o acesso, de sua própria subjetividade, à sutileza, delicadeza e multiplicidade de sentidos expressos nas falas dos entrevistados.

Como se trata de memórias, a questão do tempo de recordação (que funcionaria quase como um tempo de ficção) é fundamental. Esse tempo será sugerido pelos diversos acontecimentos sonoros e musicais ouvidos no filme, como se fossem recortes e fotos do álbum de memórias. A diferença, no entanto, é que, por serem sonoros, esses recortes têm o potencial de se moverem, se esgarçarem, crescerem ou diminuírem de volume, aparecem e desaparecem, enfim, de serem maleáveis e manipuláveis, como as próprias lembranças. Esse tempo, portanto, deve ser explícita e claramente expresso no decorrer do filme, cumprindo a função 
de localização de memórias (individuais e sociais) nas diversas etapas do passado, seja do remoto, seja do mais próximo.

Esse tempo de recordação será construído sobre e através do "tempo real", no qual será organizada a sequência de eventos sonoros/silêncios. Os ruídos estarão incluídos como parte importante das evocações de cada pessoa, assim como as músicas e canções significativas. O silêncio é considerado um dos elementos-chave da trilha, ponte entre o tempo real e o tempo da memória. Será usado de forma expressiva: sua ocorrência obedecerá a um projeto de linguagem no qual ele será preparado pela sequência anterior e, por sua vez, preparará a próxima, de modo a se tornar significativo em relação tanto ao discurso sonoro como ao discurso das imagens.

Ao mesmo tempo, a trilha deverá estabelecer relações entre os espaços apresentados, tanto os evocados pela memória quanto os espaços do presente salas, ruas, casas, bairros etc.

Essa composição depende essencialmente da organização rítmica da trilha, formulada sempre em relação ao ritmo proposto pela edição de imagens, à maneira de um contraponto ${ }^{19}$, e sempre pensada em conjunto com a direção.

A linguagem musical funciona basicamente estabelecendo relações mais ou menos intensas de contraste, como som/silêncio, repetição/não-repetição, lento/rápido, forte/fraco, agudo/grave, simultaneidade/não-simultaneidade etc.

É por meio da exploração dessas relações que construímos formas sonoras: peças musicais, ou, talvez melhor, objetos musicais. A trilha sonora de um filme é um grande objeto musical, em geral composto de vários pequenos objetos, organizados de forma a obter (ou a sugerir apenas) uma unidade.

\footnotetext{
${ }^{19}$ Forma de organização musical em que dois eventos sonoros independentes e com características próprias ( $p$. ex., duas melodias), interagem criando dialeticamente um terceiro evento musical, resultante dessa interação
} 
A seguir, um esboço da estrutura geral da trilha sonora como a estou propondo no estágio atual.

\subsubsection{Procedimento de composição}

Em princípio, temos três grandes classes de material sonoro a serem utilizadas. São esses materiais que, explorados e elaborados (isto é, transformados em ideias musicais), serão posteriormente organizados, transformados em objetos musicais e editados (tudo isso é trabalho de ilha de edição e estúdio), compondo, então, a trilha como um todo. São elas:

\section{A voz dos entrevistados}

A musicalidade contida na própria fala dos entrevistados é, em si mesma, uma proposta sonora a ser aproveitada como material sonoro e até mesmo como eixo da musicalidade do filme. As falas e seu ritmo, seu andamento, os silêncios nelas contidos, nos sugerirão ideias sonoras e musicais. Elas mesmas trazem em seu interior o tempo de memória que estamos propondo e que se articula com o ritmo em que vão surgindo as evocações.

\section{Os ruídos ambientes}

Ocorrências casuais e material captado: tortilha, máquina de costura, trem etc. 


\section{Músicas}

Utillização de gravações existentes - material fornecido pelos entrevistados (CDs, LPs etc.) e material pesquisado (Fábio, Bel, e toda a equipe sugere) -, composição musical (Fábio) de material para fazer ligações de cenas, comentários, etc., ou aproveitamento de trechos de canções, evocados durante as entrevistas e cantados pelos próprios entrevistados, como material para elaboração de composições e/ou arranjos.

\subsubsection{Edição e montagem}

A primeira etapa do processo de produção correspondeu à gravação das entrevistas e à seleção das sequências significativas para a construção da narrativa e do roteiro de edição.

O critério de seleção das sequências estabeleceu-se em função dos temas formulados nas entrevistas e aqueles surgidos durante as gravações. Os temas estabelecidos pelas perguntas foram: origem, imigração, viagem, da tradição aos novos costumes, questão de identidade e estabelecimento da vida no Brasil.

O visionamento em conjunto de todo o material orientou-nos quanto aos procedimentos iniciais da pré-edição, seleção dos trechos das entrevistas para a edição.

Pude compreender esse procedimento quando deparamos com a situação. Ficou evidente que o fluxo narrativo precisava demonstrar a trajetória das pessoas: elas vieram, trouxeram uma cultura ancestral e suas competências construídas. 
Sentimos que poderíamos organizar as falas por contrastes de gênero, pois há três mulheres e um homem totalizando as entrevistas. Para elas, o núcleo familiar é muito importante. E a mulher estabelece a unidade da família. Grande parte dessa unidade se expressa na cozinha.

Para todos os entrevistados, a comida representa um elemento de agregação da cultura perdida, e a mulher é responsável pelo preparo da comida, por nutrir a família e manter a conexão com a cultura ancestral.

Tínhamos, então, as diretrizes para a organização narrativa do material e as indicações para a redução das quatro horas de material bruto. Nesse ponto, PC Toledo começou a trabalhar a organização do material.

A segunda seleção foi feita na ilha de edição, utilizando os critérios de eliminação dos trechos que não tivessem conexão com os conceitos e sequências definidos. Nessa segunda seleção, PC considerou opiniões da equipe para eliminação dos trechos considerados não apropriados. Houve uma postura ética no critério de corte das narrativas dos personagens. Discutimos e estabelecemos que não faríamos cortes de forma a manipular as narrativas, a ponto de construir um significado diferente do que foi expresso. Ou seja, obedeceríamos ao raciocínio completo do tema narrado. E este princípio ético perdurará no processo de finalização.

Na segunda seleção, criou-se uma time line (duração de uma hora e trinta e dois minutos de entrevista) com os trechos das narrativas selecionadas dos quatro personagens sobre cada tema.

Para tal seleção, nomeamos as sequências de acordo com os temas das entrevistas e outros surgidos no processo de gravação. São eles, nesta ordem na time line: construção (personagens); nomes (apresentação de cada um); origem; 
vida na Espanha; guerra civil e Franco; primeiro trabalho; trabalho (outros); objetos biográficos; imigração; por que Brasil; da tradição aos novos costumes; adaptação; identidades culturais; músicas; gastronomia; viagem; considerações finais; hoje (situação atual e sonhos); momento top.

Além desse material, há as sequências das construções dos personagens. É nesse estágio que o material está apresentado junto com o texto da dissertação, no DVD entregue à banca. O corte final do documentário acontecerá depois da defesa.

\subsubsection{Inserção social}

O compromisso social inicial é o de exibir o documentário nas comunidades espanholas do Brasil e estimular um debate sobre as questões da cidadania espanhola na contemporaneidade, pois considero uma questão relevante para se discutir e descobrir. Além desse compromisso, pretendo divulgar o documentário em grupos brasileiros de pesquisa etnográfica, histórica e sociológica, de faculdades e universidades. Ele pode se constituir em recurso pedagógico de palestras e debates nesses ambientes.

\subsubsection{Procedimentos de produção que faltam para finalização do documentário}

Há vários procedimentos a serem realizados, que não foram previstos nesta fase por dependerem de datas que ficariam incompatíveis com o prazo rigoroso de depósito da dissertação.

- Gravações: serão gravadas as manifestações culturais regionais típicas de cada região dos convidados (festas regionais valenciana, andaluza, 
madrilena e catalã). A equipe de produção levará o entrevistado para participar das festas e captar suas reações nessas manifestações.

As cenas de cobertura das narrativas dos entrevistados serão gravadas com a câmera móvel. São cenas que fazem parte do cotidiano das pessoas: Mari Carmen bordando, cuidando de sua cadela, cozinhando; Margarita trabalhando em sua loja, cozinhando e no computador; José Luis lendo o jornal na piscina do prédio, encadernando um livro, assistido televisão; Carmen Baena assistindo televisão, fazendo ginástica no clube, brincando com os netos em sua residência.

- Roteiro de edição: a elaboração do roteiro de edição a partir do material selecionado e gravação das narrações.

- $\quad$ Produção de computações e telas gráficas.

- Pesquisa de imagens: será realizada a pesquisa de imagens em movimento (imagens históricas da Espanha, do Brasil e de São Paulo). Essas imagens ilustrarão trechos das narrativas em que se mencionam eventos históricos como a II Guerra Mundial, a Guerra Civil Espanhola etc.

- Iconografia e acervos pessoais que não foram pesquisados anteriormente.

- Composição de trilhas sonoras e ruídos de acordo com o desenho sonoro 


\subsection{Interlocução do método documental construído com a experiência profissional de produtora de televisão}

Conforme mencionado anteriormente, minha formação profissional se originou e se consolidou na área da produção e, ao longo de 16 anos de atuação, tenho desenvolvido várias funções nessa área. Somado a este fator, tive o privilégio de trabalhar e aprender com profissionais de qualificação comprovada. Tudo isso colaborou para a constituição de considerável formação profissional.

De acordo com o aprendizado construído na prática e com algumas características de personalidade, venho desenvolvendo um método de produção fundamentado em sistemáticas rigorosas e submetido aos constantes questionamentos, às evoluções e avaliações.

Posso afirmar que a função atual desempenhada por mim na TV Cultura, como coordenadora de pós-produção, caracteriza-se por um momento profissional de confluência de aprendizados (pesquisa acadêmica do mestrado, atuação como pesquisadora no Aruanda lab.doc e a experiência profissional). Percebo que, desde o início dos cursos de pós-graduação, encontro-me em um processo de qualificação profissional e deslocamento cultural-profissional.

Minha concepção de produção e de direção, apreendida no contexto de cursos ministrados pelo Aruanda lab.doc, fundamenta-se no conceito das competências gerenciais que envolvem os desempenhos de tais funções. Pois os profissionais dessas funções, cada um em sua esfera de trabalho, têm como atribuições o gerenciamento de recursos financeiros, humanos e tecnológicos. A direção gerencia a partir da criação, e a produção se articula com a direção para o gerenciamento direto dos recursos na realização do produto final. 
Atualmente, meu método de produção profissional é constituído a partir de algumas vertentes:

- Concepção e elaboração de procedimentos e sistemáticas desenvolvidas e direcionadas a cada tipo de produção, cada formato de programação da televisão. Participei de produções, em sua maioria de não-ficção, em diferentes formatos de programas (teleducação, musical, entretenimento, de ciência, educativos etc.). À medida que vivenciava essas experiências, percebia que cada formato tinha suas peculiaridades na estruturação da produção. Desde essa época, tinha a intuição da hipótese de pesquisa, de que não há método unificador para as produções audiovisuais de não-ficção.

- Elaboração e organização de documentos da produção para controle, acompanhamento e sistematização das informações ao longo do processo e de todas as etapas da produção.

- Gestão do fluxo de informação interno e externo. O fluxo interno de informação se dá entre os profissionais da equipe e/ou departamento. E o fluxo externo das informações parte da equipe para outros departamentos e instituições.

- Gestão de recursos humanos (a contratação e gestão dos profissionais), fundamentada nas competências.

- Gestão dos recursos tecnológicos. Significa planejar e coordenar a utilização racional de equipamentos, de forma a otimizar custos e atender a todas as equipes.

- Gestão dos recursos financeiros. Elaboração de orçamentos e acompanhamentos periódicos dos custos, a fim de articular a previsão 
orçamentária com os gastos reais, e avaliação final do processo, no cruzamento de informações se correspondiam ao previsto.

- $\quad$ Contribuição e compromisso profissional na formação e qualificação dos profissionais das equipes. Há um compromisso pedagógico de minha parte na formação de estagiários e qualificação dos profissionais que integram as equipes de trabalho, como os assistentes de produção e produtores.

Ao longo de minha experiência profissional de produção, havia constatado a hipótese de pesquisa do Aruanda lab.doc de forma intuitiva e inconsciente.

Sempre gostei de refletir sobre o processo da produção antes, durante e depois da realização. E fazia isso trocando informações com alguns colegas das equipes, aqueles que tinham por costume a reflexão sobre sua prática. Nosso objetivo maior era o desenvolvimento e aprimoramento profissionais.

De acordo com minha hipótese formulada na atuação profissional, cada formato diferente impunha as exigências de métodos de produção diferentes.

Isso significa que a metodologia dos procedimentos da produção da série "Ver ciência", da TV Cultura, era própria daquela série. O programa discutia assuntos das áreas das ciências, por meio da entrevista da apresentadora com especialista do assunto (no estúdio), a partir do tema de um documentário, produzido por produtores independentes internacionais, apresentado no programa. Nesse processo de produção, previa-se a gravação, a elaboração do roteiro da apresentadora, a gravação no estúdio com o especialista e a finalização do programa.

Por outro lado, os procedimentos de produção da série "Invenção do Contemporâneo" compreendiam procedimentos diferentes, como a roteirização da palestra gravada, edição e finalização na TV Cultura. 
Os conteúdos dos programas tratavam de vários temas, por meio de palestras gravadas e transformadas em programa de televisão. Produziam-se artes em computação gráfica (cartelas, animações), previa-se gravação de voz over com apresentador e finalização. Portanto, outro método próprio a esse conteúdo e características do material fornecido para a TV (pois as gravações - cortadas no switcher - eram realizadas por uma produtora independente; a TV Cultura recebia esse material para finalizar os programas, após a gravação).

Com minha participação no grupo Aruanda lab. doc, por meio de pesquisas, discussões e cursos, pude tornar essa reflexão mais consciente, no sentido de aprofundar e ampliar as dimensões da problemática do método da produção.

A hipótese elaborada no contexto do grupo de pesquisa postula que, na medida em que os audiovisuais de não-ficção têm por condição fundante o compromisso com o real, não há uma metodologia unificadora dos procedimentos de produção.

Passei a desenvolver essa reflexão no ambiente profissional. Tenho elaborado tal hipótese por meio de uma avaliação crítica acerca da composição e do gerenciamento das equipes de produção, do departamento da gerência de produções, da diretoria de programação (à época) e da TV Cultura como instituição pública, responsável pela produção e exibição de conteúdo televisivo para transmissão em canal aberto.

Tenho conhecido recentemente, na TV Cultura, os princípios de gestão de projetos por meio de um curso aplicado à utilização do software "Primavera", ferramenta da área de TI (tecnologia da informação) para gerenciamento de projetos. Pretendo me aprofundar nesses conhecimentos, pois os conceitos e métodos advindos da área da administração na gestão de projetos agregarão valor à 
minha formação da produção. Pude constatar que, na produção, fazemos a gestão de projetos, mas, em grande medida, de forma intuitiva.

As reflexões desenvolvidas ao longo dos últimos anos me propiciaram o conhecimento dos temas e conceitos necessários para reflexão acerca da produção, a articulação e formulação de análise crítica e, finalmente, a gestão da carreira profissional. Isso representa objetividade, otimização de recursos e tempo a serem investidos em prol de minha qualificação profissional.

Passar da produção de televisão para a produção do documentário, considerando o período anterior de conhecimento construído no contexto do Aruanda lab.doc, significou um aprendizado importante para o exercício prático do mestrado. Entretanto, ao iniciar a produção das entrevistas, colocava-me na posição de aprendiz de diretora e de profissional de documentário, pois ainda não havia trabalhado com esse formato nem no exercício da direção.

Estava aberta e alerta a cada etapa do processo de produção. Sempre me questionava e discutia com a equipe como poderíamos estabelecer os procedimentos de produção mais adequados àquele formato.

Pensava que minha experiência se constituía, metaforicamente, em uma paleta, que estávamos "pintando um quadro juntos" e que poderia dispor daquela gama variada de cores (procedimentos de produção) para realizar o trabalho. Estava aberta a mudar poucos ou muitos procedimentos de produção construídos e criar outros novos necessários.

A construção do método de produção no exercício prático documental estabeleceu-se da seguinte maneira: apresentei a proposta estética inicial do documentário à equipe e, por meio de reflexões e discussões em reuniões semanais 
durante todo o processo da gravação, negociávamos e ajustávamos os procedimentos que atendessem às necessidades da direção e produção do projeto.

Tais negociações e ajustes se faziam necessários porque aquela era a primeira oportunidade de trabalho da equipe. Implicou em tempo de conhecimento do método e estilo de trabalho de cada profissional até se constituir a criação do método de produção coletivo.

Além desse fator, havia o aspecto das formações e experiências profissionais diferentes. Viemos de várias áreas de formação: PC Toledo e eu somos de Rádio e TV. Também sou de Jornalismo, Geografia e Cinema. Vanderley, Economia; Fabiana Sanches, Música e o diretor musical Fábio Cintra, Teatro. Mas há o aspecto positivo dessa hibridização, pois há a diversidade de visões e posicionamentos frente ao trabalho.

Apesar de todas as diferenças, PC Toledo, Fabiana e Vanderley e eu temos um elemento comum a nosso favor: (somos integrantes do Aruanda lab.doc. Vínhamos participando do grupo há quatro anos. Tínhamos como elemento integrador as discussões compartilhadas e sistematizadas, os temas discutidos, pesquisados e elaborados, e a postura ética discutida no grupo e praticada no exercício da profissão. Ou seja, esta vivência foi o substrato e componente responsável por plasmar a relação do trabalho coletivo.

No contexto desta equipe, a produção foi desenhada: as pesquisas preliminares realizadas, gravações, transcrições e decupagens prontas, e houve as seleções das cenas para edição e entrega à banca examinadora.

Ao final do processo, pude comprovar, na prática desta produção, a hipótese do método de produção documental formulado pelo Aruanda lab.doc: na produção documental, os métodos se impõem pelo embate entre o assunto, o olhar do 
realizador e as condições de produção e pela busca de um equilíbrio entre os conceitos e métodos preestabelecidos e aqueles estruturados historicamente e, diretamente, na prática.

A equipe de produção assistiu aos trechos escolhidos das entrevistas e constatamos a particularidade de meu olhar para o tema e para cada entrevistado. Isso se expressa por meio das perguntas elaboradas (várias delas diferenciadas a cada entrevistado), e as repostas selecionadas se compõem em conteúdo peculiar, cuja característica marcante é a autoria plasmada pela relação e vínculos afetivos construídos entre mim e os personagens. Vínculos variáveis, na medida do grau de amizade e/ou proximidade com cada entrevistado, mas comum a todos no sentido de serem pessoas com as quais já mantinha tal vínculo e amizade ou que fomos construindo ao longo do processo de produção.

PC Toledo mencionou (após assistir ao material selecionado para edição) que, quando a narrativa for construída (editada e finalizada), o documentário não será acerca da história da imigração espanhola em São Paulo, mas sobre as memórias individuais dos imigrantes, personagens. Essas memórias enfocarão momentos significativos de suas trajetórias de vida, revelando as contradições das vozes dos entrevistados e cujo foco são as questões da construção das identidades culturais. Tema caro à minha busca pessoal e aos meus questionamentos existenciais.

A equipe propôs que minha presença e intervenção no eixo narrativo, na finalização, se constituam por meio de gravação de texto em voz over. Esse texto deverá ter caráter reflexivo sobre o processo de produção, revelando minha busca pessoal. Outra opção, sugerida por eles, seria a gravação de minha entrevista, refletindo sobre o processo de minha busca, sobre o processo de produção e sobre 
o material gravado, ao estilo da narrativa do documentário Santiago de João Moreira Salles.

De acordo com minha concepção, a narrativa do documentário finalizado seria apenas constituída pelas vozes dos entrevistados e voz over de narrador, sem minha intervenção. Mas acredito que a equipe tenha razão, devido ao caráter autoral do tratamento do tema. Entretanto, este assunto será decidido posteriormente, pois é necessário ser elaborado interiormente por mim.

No que diz respeito às condições de produção, houve um impedimento financeiro para o gerenciamento do projeto. Por isso, o subdimensionamento da equipe foi fator determinante para o surgimento de problemas na qualidade do material gravado com a câmera móvel. Precisávamos de outro cinegrafista com experiência. Com o material gravado (subexposição da fotografia e problemas de ruídos do áudio captado em vários trechos), não estou certa se poderemos utilizar os trechos escolhidos para a finalização.

Esse problema técnico não pode ser solucionado ao longo do processo; é um fator limitante. Uma avaliação técnica posterior pode, ou não, condenar o material. Como solução alternativa, estou prevendo mais gravações com cada personagem em situações cotidianas, utilizando a câmera móvel. Essas cenas servirão para "cobertura" de trechos das narrativas dos personagens e colaborarão nas construções dos personagens.

Finalmente, na reflexão da hipótese de pesquisa, cabe analisar a busca do equilíbrio entre os métodos estruturados na prática e os conceitos e métodos construídos. De acordo com o processo de produção, constato que o maior equilíbrio encontrado foi na área da produção. 
A produtora e eu conseguimos estabelecer uma relação de complementação profissional na estruturação da produção. Suas habilidades na elaboração de planilhas criaram vários documentos, novos para mim e úteis na produção, como a "ordem do dia" sintetizando todas as informações de que a produção necessitava. Também elaborou o orçamento de forma clara e sucinta e gerenciou a produção de forma criativa, traço de sua personalidade.

$\mathrm{Na}$ direção, houve um desequilíbrio, no sentido de que eu deveria ter me preparado melhor para o desempenho de tal função. Apesar dos problemas não superados, gostei da experiência de atuar na direção (em formato de documentário). Penso que, para continuar nesse caminho,, será necessário vivenciar a experiência, talvez na área da produção de documentário, depois como assistente de direção para, enfim, com qualificação e conhecimento maiores, exercer a função de diretora.

No exercício prático, ficou comprovado que o projeto, como proposta inicial de produção, sofreu alterações quando do embate com o mundo histórico. Ou seja, o método se constrói e se impõe na prática e no embate com o real em várias instâncias: na adaptação às limitações financeiras para delinear a gestão do projeto, na configuração e desempenho da equipe e no prazo disponível para executar tal produção.

\subsection{Coautoria do trabalho coletivo e a relação entre a equipe de produção}

No documentário, o princípio fundante é o compromisso com o real, o mundo histórico. Essa natureza de produção é totalmente diferente da produção de ficção, em que todos os elementos constituintes do processo são controlados: atores, equipe de produção, equipe técnica, cenários, figurinos, maquiagem etc. 
No documentário, a produção tem controle parcial do assunto e do roteiro a ser gravado: portanto, no embate com o real, a equipe de gravação precisa estar atenta constantemente ao que vai acontecer ao seu redor.

As situações e cenas previsíveis de gravação são previamente produzidas, entretanto, o ritmo e o movimento das ações do “'mundo histórico”, como nomeia Bill Nichols (2005), acontecem sem que tenhamos o poder de interferência sobre elas. Para o documentarista e a equipe trabalharem nesse contexto, é necessária a observação, atenção, sintonia e humildade por parte de todos para captar qual é o momento oportuno. Muitas vezes, essas percepções e tomadas de decisão se dão em questão de instantes. Daí a necessidade da sintonia da equipe.

Caso essa percepção da equipe acerca do mundo histórico não aconteça, corre-se o risco de perder oportunidade única de gravar uma situação.

No exercício prático, tivemos de construir a sintonia da equipe e o trabalho coletivo, pois, no início da produção, percebi alguns aspectos favoráveis e desfavoráveis para tal construção. Nossas formações diferenciadas eram positivas, por contemplar a diversidade de experiências profissionais, porém foi necessário um tempo inicial de conhecimento dessas experiências e métodos próprios de produção, construídos individualmente ao longo da trajetória profissional de cada um, para, depois, construirmos o método de produção da equipe e do tema do documentário.

PC Toledo ainda não tinha experiência significativa em trabalhos coletivos, pois, na maior parte de suas produções, costuma trabalhar sozinho e desempenhar várias funções. Mas, no início da produção, comentou que estava interessado em aprender a trabalhar coletivamente. 
Minha formação é de jornalista, e a experiência profissional adquirida, principalmente na produção de televisão, ensinou-me a conceber o trabalho da equipe como um trabalho coletivo a ser construído e cultivado cotidianamente.

Fabiana Sanches, a produtora, acabara de participar de um curso de cinema de ficção e estava empenhada em desenvolver seu método próprio de produção para trazer como aporte à produção do documentário.

Fábio Cintra, diretor musical, com sua experiência na produção teatral de trabalho coletivo, incorporou seu método de criação desde o início do processo da produção. Participou das reuniões e das gravações das entrevistas para conceber a criação do desenho sonoro. Sua capacidade de adaptação colaborou para a fácil integração na equipe.

Com a experiência de se produzir um documentário com a proposta de um desenho sonoro, descortinaram-se, para nós da equipe, diversas possibilidades no manejo da expressão sonora a partir de conceitos adotados pelo diretor musical. Trabalhar com ele tem colaborado para nossa qualificação profissional, pois a presença de um diretor musical é mais comum em outros tipos de produção. Para a equipe toda está representando uma experiência nova.

No caso da nossa produção, na finalização do documentário, a existência do desenho sonoro possibilitará a composição de trilha explorando os diferentes gêneros musicais existentes na Espanha, contemplando a questão da diversidade cultural do país.

Vanderley Mastropaulo acabara de receber o título de mestre e é pesquisador do Aruanda lab.doc. Tinha o objetivo de conhecer a prática da produção, uma vez que sua pesquisa está no âmbito da teoria. 
Vanderley desempenha várias funções, como assistente de câmera, assistente de produção e pesquisador nos projetos em desenvolvimento. $\mathrm{Na}$ equipe do exercício prático, além de exercer essas funções, foi operador da câmera móvel.

Entretanto, essas questões foram superadas e conseguimos construir 0 trabalho coletivo tendo como fator integrador a participação da maioria da equipe no Aruanda lab.doc.

Além dessa característica integradora, tínhamos objetivos comuns na postura profissional: construção do método próprio a esta produção, tendo a postura ética como elemento que perpassa todo o processo; a construção do espírito de equipe por meio do trabalho coletivo e a contribuição na formação e aprimoramento profissionais dos integrantes da equipe.

Queríamos aprender com o processo, construímos a autoria e o método de produção em cada etapa, individual e coletivamente. Tínhamos a expectativa de nos superar a cada etapa. A prova disso foi vivenciar o processo de aprendizagem crescente e o aperfeiçoamento profissional nas gravações das entrevistas. Quando gravamos a última entrevista, havíamos estabelecido o espírito de equipe, utilizando estratégias (na relação com a entrevistada e na operação dos equipamentos) mais elaboradas, aprendidas nas entrevistas anteriores.

Desde o início da produção, apresentei minha proposta estética e explanei minha filosofia de trabalho de gestão de produção baseada no princípio da construção do trabalho coletivo. Ou seja, o aporte que cada um pode oferecer a partir de suas competências e experiências profissionais ao trabalho e ao grupo. Esses fatores somados constituem-se no trabalho coletivo. E esse aporte se dá, principalmente, pela atuação criativa de cada profissional. 
Por meio desse conjunto de atuações, constrói-se a coautoria no trabalho coletivo. Isso se reflete na tela, ou seja, o produto final expressa a articulação e o tipo de atuação que aconteceu entre os profissionais ao longo do processo de produção.

Para se construir o método de produção baseado no trabalho coletivo, foi preciso equalizar as diferenças (de métodos e conhecimentos) da equipe e construir o método de produção próprio ao exercício prático. Resolvemos, então, estabelecer reuniões semanais que tinham dois momentos: o primeiro, mais objetivo, com discussões pontuais de acordo com a pauta e o segundo era um momento de conversas informais de integração durante o preparo e a hora do jantar.

Nesse contexto, definimos a linguagem da direção de acordo com nosso estilo de trabalho. Temos características (PC Toledo e eu) do modelo observativo de Bill Nichols (2005), devido à nossa prioridade ética em lidar com a sensibilidade e o cuidado no embate com os entrevistados. Ou seja, não queríamos que a câmera fosse um elemento invasivo no ambiente privado dos entrevistados.

Nas reuniões, conhecemos o trabalho do diretor musical, que explicou os conceitos com os quais trabalha. Projetou um DVD da peça "Macbeth", cuja direção musical é de sua autoria e explicou os momentos significativos de sua composição sonora.

Concebíamos os roteiros de gravação (ordens do dia) juntos e delineamos a linguagem das sequências: nas entrevistas, definimos que eu faria as perguntas dando preferência ao conteúdo e ângulo de visão do entrevistado. Mas concordamos que, se alguém da equipe tivesse alguma pergunta pertinente ao assunto, seria formulada, pois assumiríamos, na edição, o desvio do ângulo de visão 
do entrevistado. O mais importante seria aproveitar o momento propício para se abordar a questão.

Desde aí se caracteriza, a meu entender, a coautoria. Exemplo dessa situação foi a gravação com José Luis depois da entrevista com a câmera fixa. PC Toledo estava à mesa, operando a câmera móvel no final do horário do almoço e sutilmente começou uma entrevista em tom de conversa descontraída, que rendeu uma performance do entrevistado muito diferente da anterior, com o personagem construído diante da câmera fixa.

Durante as reuniões, também definíamos os sets de gravação, o estilo da linguagem das sequências dos objetos biográficos, da memória afetiva e prevíamos os ruídos e sons que faziam parte de cada ambiente. Saíamos com o roteiro elaborado para a gravação.

Entretanto, se, no embate com o mundo histórico, deparássemos com algo diferente do previsto, gravávamos aquela situação, como foi o caso dos momentos pós-gravações das entrevistas. Nesses momentos, havia muita descontração, e o entrevistado interagia com a câmera de forma mais solta. Essas conversas aconteciam, geralmente, nas cozinhas e no momento em que comíamos algo oferecido pelos entrevistados.

Dava-me a impressão de que eles nos diziam, de forma indireta, que seria naqueles lugares e naquelas circunstâncias que eles preferiam ser gravados, representados.

Nós (a equipe de gravação) fomos aprendendo com os entrevistados nesse contexto de percepção sensível. Por isso, passamos a gravar tais situações. Mas nessa concepção da direção ainda faltaram as cenas dos entrevistados preparando 
as refeições. Pois notamos, ao longo das gravações, que, para eles, a comida é um elemento cultural integrador deles e suas famílias.

Portanto, depois da experiência das gravações, aprendemos o valor e a necessidade de a equipe de documentário desenvolver uma expertise nesse formato. Ressaltando que a interação desta equipe, no encontro e embate com o mundo histórico, precisa ser baseada em códigos de comunicação verbais e nãoverbais.

A construção do trabalho coletivo deu-se por meio dos diálogos e também pela postura de colaboração entre todos. A troca de conhecimentos sempre fluiu, no sentido de compartilhar e de participar na qualificação profissional um do outro.

Sempre tive curiosidade de aprender detalhes da área técnica, bem como esclarecer questões do aspecto da produção de documentário. Aproveitava os momentos de conversas descontraídas, como a separação do equipamento, para tirar tais dúvidas, com PC Toledo.

Fabiana estava acostumada a trabalhar com PC Toledo e com Vanderley Mastropaulo. Eles têm trabalhado juntos desde o início do ano de 2009 em outros projetos e têm constituído uma equipe dentro de nossa equipe do documentário, que, por sua vez, é uma parte do Aruanda lab.doc.

O compositor Fábio Cintra esteve atento a todos e a tudo durante as gravações. Ele estava aprendendo muito do processo de produção do documentário. Além disso, sua postura de profissional da área de áudio nos orientava nas gravações dos áudios necessários para a produção do desenho sonoro.

Esses procedimentos colaboraram, em grande medida, na formação e qualificação profissionais de todos da equipe. Vanderley vem construindo sua formação profissional com afinco, empenho, dedicação e seriedade. 
Ele participou de várias etapas do processo: na gravação, transcrição e decupagem da maior parte do material bruto e na edição. Pôde avaliar seu trabalho de operação da câmera móvel no processo de decupagem e transcrição. Nós dois havíamos assistido ao material bruto inúmeras vezes para realizar esse procedimento. $\mathrm{Na}$ ilha de edição, constatamos que conhecíamos profundamente cada cena, cada tomada, cada fala dos entrevistados. O fato de ter atuado em todas as etapas da produção permitiu a ele compreender o processo de forma completa.

Fábio Cintra deve ter-se sentido inserido no contexto de um estilo e formato de produção audiovisual que trazia muitos elementos novos a sua formação profissional. PC Toledo exercitou a construção do trabalho coletivo nas reuniões, nas gravações e na edição. Para selecionar o material que constituirá o eixo narrativo da finalização, recebeu minhas indicações, ouviu opiniões de Vanderley e Fabiana nos momentos de decisão para selecionar o material que fosse pertinente à edição.

Com Fabiana, desenvolvi o exercício da criatividade e o senso crítico constante, aplicados à produção e à direção. E acredito que todos da equipe tenham construído conhecimento significativo, que contribuirá com suas qualificações profissionais. Certa ocasião, Vanderley afirmou que saiu da experiência da produção do exercício documental transformado.

Essa opção de trajetória talvez seja a mais difícil, pois ela demanda empenho, disponibilidade de tempo, tolerância, respeito e abertura para o diálogo por parte de todos na construção do trabalho coletivo. Equacionar as opiniões diferentes, construir o consenso e encontrar soluções demanda muita energia. 
Depois de ter passado por essa experiência, há uma equipe constituída, sintonizada e qualificada profissionalmente. Preparada para diferentes tipos de produção.

Ao final da produção do exercício prático, criamos nosso método de produção. Estamos atentos à construção desse método e em constante questionamento e avaliação (individual e da equipe) para outros projetos.

$\mathrm{Na}$ relação com os entrevistados, sentimo-nos enriquecidos por termos sido ouvintes das suas narrativas, por termos aprendido com eles e com suas histórias de vida. Saímos transformados dessa experiência humana.

\subsection{Autoria e generosidade - humildade em relação ao tema}

A reflexão acerca da autoria no documentário será elaborada à luz das reflexões e discussões do Aruanda lab.doc., uma vez que há poucos estudos sobre esse tema.

O estímulo inicial do documentarista é a paixão pelo seu tema. É ela que impulsiona todo o processo de realização de um documentário. Ela determina o olhar do realizador e o tratamento que dará ao tema. Esses componentes pessoais e particulares iniciam o processo de delineamento da autoria no documentário.

A autoria desse exercício prático foi construída a partir da minha paixão pela cultura espanhola, apesar das questões psicológicas que não estavam resolvidas. Paixão que faz parte de minha história de vida e de minha identidade cultural. $\mathrm{O}$ tratamento do tema do documentário foi norteado, primeiramente, pelas relações afetivas e éticas (entre os entrevistados e eu) construídas anteriormente à produção, 
e que perdurarão ao tempo de realização do documentário. Por meio dessa relação de afetividade e sensibilidade humanas, parti para o embate com o mundo histórico.

O segundo aspecto para o delineamento dessa autoria foi minha relação com o tema da imigração, meu olhar para a Espanha contemporânea e para os espanhóis imigrantes que vivem na cidade de São Paulo, olhar este que parte da condição de filha de espanhol nascida no Brasil. Esses fatores contribuíram para o processo de aproximação dos entrevistados, que pressupunha a criação de vínculos e compromisso de respeito e afeto.

Outro aspecto fundamental ter vivenciado a direção do documentário a partir de meu lugar de origem: a produção. Fiz questão de desempenhar a produção do exercício na pesquisa de personagens para manter os vínculos afetivos construídos nas relações pessoais e fazer a transposição para a relação documentarista entrevistados.

A estruturação da produção abrigou características de meu método de trabalho acrescido das sugestões e aportes dos profissionais da equipe. Portanto, priorizou-se a organização, a sistematização e a disponibilização das informações para toda a equipe. Elaboraram-se documentos específicos para este projeto, e criou-se um ambiente propício ao diálogo, à troca de experiências, enfim, à constituição do trabalho coletivo.

Segundo a Profa. Marília Franco, o documentarista precisa ter generosidade e humildade para se relacionar com o mundo histórico e com o tema. De acordo com minha percepção na experiência do exercício prático, ter generosidade e humildade significa estar aberto para apreender o que o mundo histórico vai lhe revelar. Tinha a curiosidade de uma pesquisadora, em busca de respostas às minhas perguntas 
(argumento) acerca do tema. Respostas essas que começaram a surgir no processo de pesquisa bibliográfica.

No embate com o mundo histórico, o princípio de interação que adotei foi a noção dos limites no embate com esse mundo. A ideia de que o documentário registraria apenas um recorte restrito desse mundo por meio das narrativas de vidas dos entrevistados era clara desde o início.

Com essa postura, constatei o que significa lidar com o mundo histórico. Mundo esse que tem seu ritmo e movimento próprios, portanto, com vários elementos de imprevisibilidade que acontecem no encontro e no embate.

A postura de generosidade e humildade possibilita que o documentarista lide com esse grau de imprevisibilidade, transformando essa característica na riqueza do documentário.

Imbuída dessa postura de curiosidade de quem está se iniciando em uma experiência e querendo aprender e compreender o outro, sentia-me aprendiz de documentarista.

E como aprendiz de um exercício prático de produção, exercitei a atenção, a percepção, a sensibilidade, a intuição e a receptividade para captar o que o mundo histórico iria me transmitir.

Com essa postura de abertura, pudemos vivenciar momentos significativos durante as gravações. São situações imprevistas que aconteceram de acordo com as circunstâncias do momento e cujo valor documental tem caráter expressivo. São cenas das quais guardo boa recordação e afeto.

Tais cenas foram gravadas nos momentos descontraídos na interação com os personagens. São humanamente mais reveladoras. Revelam 0 fluir da espontaneidade das pessoas e a demonstração de seus sentimentos. 
A título de ilustração, posso citar algumas cenas em que Margarita, no final da entrevista, convida-nos para tomar um lanche na cozinha. Gravamos as sequências das conversas com ela e ela revelou vários episódios que não contou na gravação da entrevista. Seu tom era de alívio e satisfação por desfrutar daquela conversa conosco.

A câmera também captou a narração de José Luis, meu pai, quando apresenta um objeto biográfico (um dicionário do idioma espanhol) e comenta sobre como ganhou, de quem e sua relação de afetividade com ele.

Nessa mesma gravação, surpreendi-me quando sua esposa, Cidinha, minha mãe, "reivindicava" que fosse gravada. Ela queria participar do documentário, assim como participa da vida de José Luis. Vanderley gravou cenas dela preparando a comida na cozinha e, depois, na hora do almoço, explicando a receita da tortilla.

Os registros gravados das cenas que não havíamos produzido trazem-nos o elemento surpresa ao rever o material gravado. Eles se constituem nas pedras de toque desse material, pois emanam a espontaneidade e o frescor de cenas gravadas à medida que os fatos iam acontecendo, que o mundo histórico se revelava a nós. Se as produzíssemos, tais cenas não guardariam tamanho frescor e espontaneidade.

Talvez resida nesse aspecto o diferencial da produção desse estilo de documentário.

Espero que este seja apenas o começo do processo de aprendizagem. Gostaria de vivenciar a produção e direção do documentário em outras ocasiões, para ser surpreendida pelo inesperado. 


\section{CONSIDERAÇÕES FINAIS}

Esta pesquisa acadêmica teve por objetivo a utilização do documentário como meio constituinte e significante para a reflexão sobre a construção das identidades culturais de imigrantes espanhóis na cidade de São Paulo. Para tanto, compreendeu a produção de um exercício prático, em formato de documentário, e a elaboração de um texto acadêmico que contemplou a reflexão sobre o método de produção construído durante a produção do exercício prático.

A reflexão produzida foi feita a partir de aproximações com métodos de produção de antropólogos-realizadores e também com o método do documentarista Eduardo Coutinho. Levou-se em conta, ainda, a hipótese elaborada no contexto do laboratório Aruanda lab.doc., do qual faço parte. Esse grupo de pesquisas, que se preocupa em refletir sobre as diferentes formas de produção de audiovisuais de nãoficção, postula como hipótese de pesquisa que não há uma metodologia única ou unificadora para o documentário, na medida em que ele tem como princípio fundante o compromisso com o real.

Nesse contexto, é importante dizer que a realização do mestrado compreendeu a construção de conhecimentos e a superação de desafios nas esferas acadêmica, pessoal e profissional.

$\mathrm{Na}$ esfera acadêmica, a experiência significou a construção de conhecimentos acerca da metodologia de pesquisa científica e da escritura da dissertação.

Ao final do processo, pude comprovar que minhas estratégias e procedimentos de pesquisa necessitam de aprimoramento, no sentido de se estabelecer mais rigor na organização das informações. Esse aprimoramento será 
desenvolvido a fim de me preparar para realizar a pesquisa na categoria compatível com o nível de doutoramento.

A escritura da dissertação, por sua vez, representou o início do processo de construção do conhecimento científico e, ao mesmo tempo, o desafio de aprender a linguagem acadêmica e o rigor da formatação do texto.

Além desses desafios, deparei com as dificuldades e as responsabilidades que se impõem quando se pesquisa algo que conta com pouca literatura acadêmica com a qual dialogar. Face ao exposto, é imperativo ressaltar que as reflexões desenvolvidas, cujo foco foi o método de produção, foram orientadas, em grande medida, pelos estudos, debates e práticas desenvolvidos no grupo Aruanda lab.doc.

Por se tratar de uma dissertação que realizou abordagens inéditas em diversos aspectos, esta pesquisa possivelmente apresentará incompletudes. Entretanto, tenho por certo que ela contribuirá para estudos posteriores, que aprimorarão e aprofundarão as ponderações a que cheguei no final deste percurso de pesquisa.

$\mathrm{Na}$ esfera pessoal, o desenvolvimento do trabalho teórico, e, principalmente, do exercício prático, propiciou uma reflexão sobre a construção de minha identidade cultural. O caminho percorrido trouxe o apaziguamento de inquietações, no que diz respeito à aceitação da identidade espanhola e a coexistência dela com minhas outras identidades (brasileira e latino-americana).

Um fato que contribuiu significativamente para esse apaziguamento foi a revelação na entrevista de Margarita. Ela narrou suas opiniões acerca de sua identidade cultural e atribuiu a dimensão humana a sua concepção.

Interpretei, portanto, que a reflexão acerca da construção das identidades culturais adquire um valor superior à esfera das identidades regionais. Com a 
reflexão de Margarita, constatei que os valores relevantes extrapolam essa esfera e alcançam a esfera humana.

Na dimensão profissional constatei, igualmente, um importante crescimento, decorrente da experiência de me perceber construindo novos conhecimentos. A realização do mestrado possibilitou um deslocamento profissional que me permitiu vivenciar o trabalho com a produção na função de diretora de um projeto autoral, experiência inédita na minha trajetória profissional.

A autoria foi construída, primeiramente, por meio de um projeto de lastro acadêmico. Isso significou a articulação da experiência prática com a construção do conhecimento acadêmico. A proposta estética para o exercício documental foi elaborada levando em conta essas duas dimensões.

O processo de criação e produção do exercício prático foi realizado por meio de um trabalho coletivo e colaborativo, entre mim e a equipe da gravação. A produção foi concebida no contexto da produção independente, experiência também inédita para mim.

Essa experiência propiciou a convivência profissional de uma equipe comprometida com os mesmos objetivos de pesquisa do Aruanda lab.doc, pois a maioria dos integrantes é proveniente do grupo de pesquisa. Essas características foram fundamentais para construirmos um trabalho coletivo fundamentado no diálogo e na troca de experiências, cujo objetivo era a construção de um método de produção adequado ao tema.

Essa vivência me possibilitou compreender como se estabelece a concepção e a produção de um documentário no contexto da produção independente, fora da estrutura de uma emissora de televisão. Nesse ambiente profissional, o ritmo da produção é gerenciado pela grade de programação, e a produção trabalha na 
realização de séries de programas a fim de atender à exigência de exibição nessa grade. Ter a oportunidade de produzir sem a imposição do ritmo de produção para exibição em uma grade de programação nos deixou mais livres para a criação e produção do exercício.

Por outro lado, houve a restrição financeira. Foi necessário adaptar o trabalho às limitações impostas por meio da otimização dos recursos humanos e financeiros, que compreendeu longo período de planejamento e definiu um número mínimo de gravações .

método construído teve como proposta inicial minha abordagem pessoal em relação ao tema. Responsabilizei-me pela pesquisa de personagens e também pelo apoio à produção e direção. A proposta de direção do documentário relacionouse com o princípio básico de minha atuação. Tal proposta fundamentou-se nas concepções de Eduardo Coutinho e Andy MacDougall, para os quais o documentário é, essencialmente, o encontro com o outro.

O conceito do encontro foi adotado por mim desde o momento da aproximação com os personagens até as gravações das entrevistas. Juntamente com a concepção relacional do documentário de Coutinho e MacDougall, utilizei também a fundamentação metodológica postulada pela História Oral, proposta por Meihy (2007, informação verbal ${ }^{20}$ ). Todos esses elementos corroboraram para a construção da minha relação (diretora) com os entrevistados.

De acordo com Meihy (2007, informação verbal ${ }^{21}$ ), para ser fazer a história oral é preciso ter um cuidado intimista com o entrevistado e, por ser uma relação de alteridade, faz-se necessário reconhecer e aceitar o outro. Meihy (2007, informação

\footnotetext{
${ }^{20}$ Informação fornecida pelo Professor Dr. José Carlos Sebe Bom Meihy, na disciplina “História Oral, memória e relações disciplinares", cursada no primeiro semestre de 2007.

${ }^{21}$ Cf. nota 20.
} 
verbal $^{22}$ ) acrescenta que entre o oralista (diretora) e o entrevistado faz-se necessário construir uma relação de respeito por meio do diálogo.

Diálogo este proposto também por D’Almeida (2008) como alternativa possível no momento do embate da entrevista, a fim de se constituir uma relação diferenciada, além da assimétrica relação de poder comumente estabelecida entre diretor e entrevistado.

Vale ressaltar que a proposta estética por mim adotada também tomou por base as concepções do "falar de perto" - speaking nearby - da documentarista Trinh T. Minh-há. Segundo minha proposta, esse conceito foi utilizado desde as aproximações até as gravações da entrevistas.

A transposição audiovisual do "falar de perto" teve, na linguagem da câmera móvel, sua expressão maior. Ela foi utilizada nas sequências denominadas "memória afetiva", em que o entrevistado apresentou pessoas e fotos que fazem parte de sua vida, e também na sequência dos "objetos biográficos", que revelaram as histórias e relações dos entrevistados com esses objetos. A linguagem dessa câmera foi concebida com movimentos suaves (planos fechados e planos detalhes). Todavia, as imagens gravadas no embate não expressaram a linguagem concebida na proposta, porque não exprimiram a proximidade e intimidade previstas.

Outro aspecto, concebido na proposta estética, que acabou sendo modificado no embate das gravações foram as sequências denominadas "construção do personagem". O objetivo da utilização desse recurso estilístico reflexivo era revelar ao público como os entrevistados se construíam enquanto personagens.

Concebi as cenas para a gravação das entrevistadas, mas duas delas (Mari Carmen Acirón e Carmen Baena) não concordaram com a proposta de gravá-las.

\footnotetext{
${ }^{22}$ Cf. nota 20.
} 
Elas alegaram que não se sentiam à vontade nas situações sugeridas por mim, tais como se maquilando, mostrando as roupas que iriam vestir etc. Aceitei suas argumentações, primeiramente, pelas questões éticas envolvidas - para mim, foi importante não forçá-las a gravar uma cena na qual não se sentiam representadas e, em segundo lugar, porque notei que a aproximação afetiva e de respeito eram mais relevantes para obter as narrativas do que a proposta estética anteriormente construída "na teoria", em projeto.

Neste ponto, foi estabelecida uma negociação entre a entrevistadora e os entrevistados. Vale lembrar que, conforme o método de Coutinho, “(...) o documentário é negociação de desejos mas também de coisas concretas - horários, disponibilidade e condições de produção". (LINS, 2007, p. 119).

As entrevistadas não aceitaram gravar as cenas de construção de seus personagens conforme minha concepção. Todavia, é curioso notar que elas gravaram as cenas de construção de seus personagens segundo suas próprias concepções. Eis aqui um fato digno de nota e reflexão sobre os encontros e embates que se dão quando da realização de documentários.

Como exemplo posso citar que Margarita estava maquilada e com o cabelo penteado. Seu figurino era composto de um vestido estampado e sandálias brancas, combinando com os tons do vestido. Tivemos a oportunidade de gravar Margarita em diferentes ambientes e performances e sem produção prévia: em conversa descontraída no terraço, na sequência "memória afetiva" no quarto de hóspedes, mostrando seus discos e livros, na entrevista, sentada na sala e na cozinha, e com a equipe, depois da gravação, compartilhando o lanche típico catalão. Em cada momento, ela construiu um personagem diferente. Na edição, vamos compor essa diversidade de personagem. 
Carmen Acirón estava pronta para a gravação ao chegarmos. Usava uma camisa colorida listrada, estava maquilada, tinha as unhas pintadas e o cabelo tingido. Carmen Baena, por sua vez, vestia uma roupa simples (blusa e calça), a seu estilo. Usava, ainda, munhequeira e relógio.

José Luis também já se encontrava arrumado para a gravação quando a equipe de filmagem chegou para a entrevista. Por uma questão técnica, tivemos que propor a ele que trocasse de camisa, o que nos levou a gravar as cenas da construção do personagem por conta desse momento. Esse foi mais um momento inusitado do documentário, pois não havia produzido a construção de personagem com ele devido ao seu temperamento marcadamente inflexível. Acreditava que ele não aceitaria gravar esse tipo de sequência. Todavia, para minha surpresa, ele gravou e interagiu com a câmera durante todo o em que durou a cena.

O embate entre o mundo histórico e a proposta estética elaborada inicialmente como projeto do documentário possibilitou-me constatar a hipótese de pesquisa do Aruanda lab.doc.: o método pode estar desenhado no projeto, mas é o embate da gravação que o define e o consolida.

Vale ressaltar, neste ponto, que essa mesma hipótese é encontrada no método de Coutinho já que, para ele, quando ocorre um embate, quem deve "ganhar" é o entrevistado, para que o documentarista possa "ganhar" o seu documentário.

O que se estabelece, portanto, é uma relação dialética - entre diretora e entrevistados - no momento do embate. Relação essa caracterizada pela alteridade, segundo D’Almeida (2008). A partir de todas essas questões, foram sendo estabelecidas as vertentes do encontro e do embate na reflexão sobre as gravações. 
Por meio da experiência da produção documental, pude constatar que o momento mais significativo do embate se configura no instante em que ocorrem as gravações. Isso porque é nesse cenário que ocorre a maior parte das negociações com os entrevistados. E, segundo Coutinho, o fundamental do documentário é o instante do encontro. $E$, se ele não acontece, não tem filme. $E$ como o diretor depende inteiramente do outro, é preciso se entregar para acontecer. (LABAKI, 2005, p. 121).

Os embates vivenciados no escopo desta pesquisa foram analisados sob os pontos de vista pessoal e profissional. Da mesma forma, refleti sobre o encontro com cada personagem.

Com efeito, devo dizer que parti do lugar de aprendiz de diretora. Assim, minha atuação contemplava uma postura de abertura para o mundo histórico, justamente por ter a noção do limite de minha atuação nesse mundo.

Neste ponto, convém sublinhar que a postura aberta é algo muito relevante nos momentos em que o documentarista precisa ter humildade em relação ao tema. Segundo minha concepção, a humildade foi necessária nos momentos em que captei as situações inusitadas, não produzidas. Nelas, uma inesperada dimensão do real se impôs perante as premissas que me serviram de base para elaborar este projeto de investigação acadêmica. Dessa forma, pudemos registrar cenas de significativa relevância documental.

Ao final desse processo, pude comprovar, sobretudo por conta do exercício prático, a hipótese quanto ao método de produção documental formulada pelo Aruanda lab.doc.: na produção documental, os métodos se impõem em decorrência do embate entre o assunto, o olhar do realizador e as condições de produção. 
Além disso, na relação de forças entre esses três elementos, há que se buscar o equilíbrio entre os conceitos e métodos preestabelecidos e aqueles estruturados historicamente e diretamente, na prática.

O assunto do documentário recebeu um tratamento particular e autoral, de acordo com a minha relação com ele. Ao assistirmos as sequências selecionadas para a edição, a equipe constatou que o fio condutor a ser estabelecido entre as entrevistas seria um texto com conteúdo reflexivo sobre minha busca e relação com o tema.

No que diz respeito às condições de produção, por um lado, houve limitação imposta pelos recursos financeiros para o gerenciamento do projeto; por outro, o fato de estarmos no ambiente da produção independente nos proporcionou liberdade de criação para a construção do método fundamentado no trabalho coletivo e com os mesmos objetivos de pesquisa do Aruanda lab.doc.

A busca pelo equilíbrio entre os conceitos e métodos preestabelecidos e os estruturados historicamente na prática esteve presente em todos os momentos da produção. Propus à equipe a concepção de um método de produção próprio ao tema, por meio da troca de experiências e do diálogo entre os profissionais. Dessa forma, conseguimos equilibrar as experiências profissionais anteriores com as necessidades específicas da produção do exercício, construindo o método próprio a essa produção.

E como proposta de direção, construí um método fundamentado no respeito e afeto na relação diretora e entrevistados, tendo o princípio ético como elemento que perpassa todo o processo.

Sinto-me enriquecida pela experiência vivenciada, pelos conhecimentos construídos e gostaria de continuar a trabalhar em produções de documentários e de 
poder continuar como caminhante, que aprendeu com a sabedoria do poeta, com o fazer documental, com a pesquisa acadêmica e com a vida: "caminante no hay camino, se hace el camino al andar". 


\section{REFERÊNCIAS*}

AGUIAR, C. Os espanhóis no Brasil: contribuição ao estudo da imigração espanhola no Brasil. Rio de Janeiro:Tempo Brasileiro,1991.

BAUMAN, Zygmunt. Comunidade: a busca por segurança no mundo atual. Rio de Janeiro: Jorge Zahar Editor, 2003.

. Identidade: entevista a Benedetto Vecchi/ Zygmunt Bauman. Tradução Carlos Alberto Medeiros. Rio de Janeiro: Jorge Zahar Editor, 2005.

BERKELY MEDIA. Catálogos de filmes. Disponível em: <www.berkeleymedia.com>. Acesso em: 18 jul. 2009.

BERNARDET, J.C. Cineastas e imagens do povo. São Paulo: Brasiliense,1985.

BOLAÑO, C. R. S. (Org.). Globalização e regionalização das comunicações.São Paulo: EDUC,1999.

BOSI, Ecléa. Memória e sociedade: lembranças de velhos. São Paulo: Companhia das Letras, 1994.

. O tempo vivo da memória: ensaios de psicologia social. São Paulo: Ateliê Editorial, 2003.

BUADES, Joseph. Os Espanhóis. São Paulo: Contexto, 2006.

CANCLINI, N. G. Consumidores e cidadãos: conflitos multiculturais da globalização. Rio de Janeiro: Editora UFRJ, 1999.

CASTELLS, M. A era da informação: economia, sociedade e cultura. São Paulo: Paz e Terra, 2003.

CORNER, Dolores M. R. A Sociedade Hispano-Brasileira de Socorros Mútuos: patrimônio cultural da imigração espanhola em São Paulo. 2000. 192f.

Dissertação (Mestrado) - Centro Universitário Ibero-Americano, São Paulo, 2000.

COUTINHO, Eduardo.; XAVIER, Ismail.; FURTADO, Jorge. O sujeito (extra) ordinário. In: MOURÃO, M. D.; LABAKI, Amir (Orgs.). O cinema do real. São Paulo: Cosac Naif, 2005.

\footnotetext{
* De acordo com: ASSOCIAÇÃO BRASILEIRA DE NORMAS TÉCNICAS. NBR 6023: informação e documentação: referências: elaboração. Rio de Janeiro, 2002.
} 
D'ALMEIDA, Alfredo Dias. O processo de construção de personagens em documentário de entrevista. In: ENCONTRO DOS NÚCLEOS DE PESQUISA DA INERCOM, 6., 2006, Brasília. Congresso brasileiro de ciências da comunicação da Universidade de Brasília, 29., 2006, Brasília.

D'ALMEIDA, Alfredo Dias. A construção do outro nos documentários de Geraldo Sarno e Jorge Prelorán. 2008. 257f. Tese (Doutorado) - Programa de Pósgraduação em Integração da América Latina - PROLAM, Universidade de São Paulo, São Paulo, 2008.

1991.

. Historiografia da imigração para São Paulo. São Paulo: Editora Sumaré,

FRANCO, Marília. Cinedocumentário: registro de memórias, inventário de culturas. In: MIRANDA, Danilo Santos de (Org.). Memória e cultura: a importância da memória na formação cultural humana. São Paulo: Edições SESC/SP, 2007.

FREITAS, S. M.; RODRIGUES O. A. Imigração espanhola no Estado de São

Paulo. São Paulo: Memorial do Imigrante, 2000. (Série resumos, 2).

FREITAS, Sonia M. de. História oral: possibilidades e procedimentos. São Paulo: Associação Editorial Humanitas, 2006.

GATTAZ, A. C. Braços da resistência: uma história oral da imigração espanhola. São Paulo: Xamã, 1996.

GIOIELLI, Rafael L.P. A identidade líquida: a experiência identitária na contemporaneidade dinâmica. 2006. 127f. Dissertação (Mestrado) - Programa de Pós-graduação da Escola de Comunicações e Artes, Universidade de São Paulo, São Paulo, 2005.

GUILLÉN, M. G. Viemos por nuestras aguas. São Paulo: Editora SENAC, 2005.

HALL, S. Identidade cultural na Pós-Modernidade. São Paulo: DP\&A, 2000.

HELLER, Agnes. O Cotidiano e a História. Rio de Janeiro: Paz e Terra, 1972.

IGUMA, A. Surdos e a comunicação audiovisual: desafiando barreiras. 2004. 169f. Dissertação (Mestrado) - Curso de Pós-graduação da Escola de Comunicações e Artes, Universidade de São Paulo, São Paulo, 2004.

KLEIN, H. S. A imigração espanhola no Brasil. São Paulo: Editora Sumaré/FAPESP, 1994. (Série Imigração, 5).

LINS, Consuelo. O documentário de Eduardo Coutinho: televisão, cinema e vídeo. Rio de Janeiro: Jorge Zahar Editor, 2007. 
MACDOUGALL, David. Beyond observational cinema. In: HOCKINGS, Paul. Principles of Visual Antropology. Berlin e Nova lorque: Mouton de Gruyter, 1995. P. 115-132.

MEIHY, J. C. B. Manual de história oral. São Paulo: Edições Loyola, 2002.

NICHOLS, B. La representación de la realidad: cuestiones y conceptos sobre el documental. Barcelona: Paidós, 1997.

NICHOLS, B. Introdução do ao documentário. Campinas: Papirus, 2005.

NOVAES, S. C. Jogo de espelhos: imagens da representação de si através dos outros. São Paulo: Editora da Universidade de São Paulo, 1993.

NOVAL, Joaquín. Temas fundamentales de la Antropologia. Guatemala: Universidad de San Carlos de Guatemala, 1972. Disponível em: <www.documentalistas.org.ar>. Acesso em: 28 maio 2007.

PARANAGUÁ, P. A. (Ed.). Cine documental en America Latina. Madrid: Catedra Signo e Imagen, 2003.

PENAFRIA, Manuela. O filme documentário: história, identidade, tecnologia. Lisboa: Edições Cosmos, 1999.

PLUTARCO. Como ouvir. Prefácio e notas Pierre Maréchaux. Tradução (grego e francés) João Cabral Mendonça. São Paulo: Martins Fontes, 2003.

RIBEIRO, José da Silva. Antropologia Visual: um processo exploratório. In: Antropologia Visual: da minúcia do olhar ao olhar distanciado. Porto: Edições Afrontamento, 2004. p. 131-176.

Antropologia Visual e Hipermedia.In: BAIRON, Sérgio; RIBEIRO, José da Silva (Orgs.). Antropologia visual e hipermedia. Porto: Edições Afrontamento, 2007.

SILVA, José R. H. Concepções de Cultura, (s/d). In: Comunidade Virtual de Antropologia, seção Divulgando seu Trabalho, edição no 12. Disponível em: $<w w w$.antropologia.com.br/divu/colab/d12-rhonorio.pdf. >. Acesso em: 28 maio 2007.

SKLAIR, Jessie. A quarta dimensão no trabalho de Trinh T. Minh-há: desafios para a antropologia ou aprendendo a falar perto. In: Cadernos de campo, São Paulo, nos. 14 e 15, p. 133-143, 2006. 
TERRA CINEMA. É tudo verdade, 1999. Apresenta pesquisa que elege os mais importantes documentários nacionais. Disponível em:

$<w w w . t e r r a . c o m . b r / c i n e m a / f e s t i v a i s / t r u e 99 \_n a c i o n a l . h t m+g e r a l d o+s a r n o+v i r a m u n d o$ + sinopse\&cd=4\&hl=pt-BR\&ct=clnk\&gl=br>. Acesso em: 18 jul. 2009.

THE INTERNET MOVIE DATABASE. 1990. Disponível em: <http://www.imdb.com/>. Acesso em: 18 jul. 2009.

TRINDADE, M. B. R. Sociologia das migrações. Lisboa: Universidade Aberta, 1995.

WOMEN MAKE MOVIES. Film by and about women. 2005. Disponível em: $<$ www. fandango.com/trinht.minhha/filmography/p198585+sinopsis+SUR+NAME+VIE T+Given+Name+Nam\&cd=20\&hl=pt-BR\&ct=clnk\&gl=br>. Acesso em: 18 jul. 2009. 


\section{ANEXOS}




\section{ANEXO A - Questionário de pré-entrevista - Carmen Baena Fernandez}

Entrevistada: Carmen Baena Fernandez

Idade: 74 anos. Está no Brasil há 64 anos.

Objeto biográfico: ela vai separar um manto (xale) de bailarina sevilhano e um leque.

Músicas: Já pesquisei com ela 06 CDs de músicas espanholas (copiados com Fábio e inseridos na lista de músicas - pasta nova que entreguei ao Fábio). Mas tem um detalhe importante: ela também gosta muito de música sertaneja. Ela tem vários CDs de diferentes duplas. Mas não me deu nenhum.

Fotos: Pedi que separasse fotos da época que chegou. Mas ela disse que não tinha fotos desta época. Acho que precisarei ir até lá depois da gravação pra ver e escolher as fotos que tiver.

\section{ORIGEM}

1) Qual o seu nome completo? E profissão?

Carmen Baena Fernandez. Sou aposentada e viúva.

2) Quando e onde nasceu?

Sevilha.

IMIGRAÇÃO

3) Quando imigrou para o Brasil?

Em 1962.

4) Que idade o senhor (a senhora) tinha?

Dez anos. 


\section{5) Qual o motivo da imigração?}

Porque meu marido tinha irmã e cunhado vivendo aqui no Brasil. Ele conseguiu trabalho no Brasil. (Ela e o marido estavam namorando há 10 anos, então casaramse na Espanha e seu marido veio para o Brasil. Depois de sete meses, ele a chamou para vir ao Brasil. Em abril de 1962.)

\section{A VIAGEM}

6) Conte como foram os arranjos para a viagem. Quem te ajudou na viagem?

Viemos no navio "CaboSanRoque". Me lembro muito da viagem!

\section{7) Quem veio contigo?}

Ninguém da minha família. Vieram 25 moças. Apenas uma era casada. (As moças e ela desceram do navio quando ele parou no Rio de Janeiro. Passearam pela cidade do Rio e depois embarcaram. Elas acharam a cidade muito bonita, na época.)

8) O que trouxe contigo na bagagem? Trouxe alguns objetos de estimação que ainda te acompanham?

Apenas as roupas da mala.

\section{9) Onde e como foi e desembarque?}

No porto de Santos. (Não gostou muito, pois o porto era um lugar muito feio. Ela também não conhecia os negros e foi quando desembarcou que viu os primeiros negros em sua vida! Em suma, ela teve uma má impressão!)

10) Qual foi a sua primeira impressão sobre o Brasil ao desembarcar?

(resposta na pergunta 9)

\section{1) A senhora gostaria de voltar a morar na Espanha hoje?}

Ela não gostaria de voltar a morar na Espanha porque tem dois filhos aqui: Arturo e Marco Antonio. 


\section{DA TRADIÇÃO AOS NOVOS COSTUMES}

11) Fale do período de adaptação: novo clima, novos costumes, novos hábitos, novos amigos, nova língua. Aspectos positivos e negativos.

Ela disse que não teve problemas de adaptação ao clima, mas ela estranhou os costumes e idioma diferentes. Quando ela chegou, estava vivendo com a família de seu marido. Ela diz que até hoje não aprendeu a falar o idioma.

Os amigos que ela arranjou já eram amigos de seu marido e da família dele. Depois que saíram da casa dos sogros, eles foram morar em Pirituba, na região noroeste da cidade, onde vive há 35 anos.

12) $O$ que permaneceu da cultura e dos costumes de origem na sua família (língua, alimentação, religião etc.)?

O que ela acha que mantém da cultura espanhola é a comida. Seu filho Arturo não gosta de paella. Mas gosta de puchero, papas guizadas, lentejas blancas. Ela gosta muito da comida brasileira e aprendeu a cozinhá-la. Mas ainda falta aprender a comida baiana.

13) O que foi incorporado da cultura da nova pátria?

(resposta na pergunta 12)

\section{QUESTÃO DE IDENTIDADE E ESTABELECIMENTO DA VIDA NO BRASIL}

14) Mantém vínculo com o país de origem (cartas, telefonemas etc.)?

Ela mantém o vínculo porque ainda tem quatro irmãos na Espanha - uma irmã e três irmãos. Costuma telefonar e se corresponder por carta.

15) Casou-se com espanhol(a) ou de outra nacionalidade?

Ela casou-se com um espanhol de Sevilha que era seu vizinho, morava na mesma rua que ela.

16) Como o senhor(a) constituiu sua família atual?

(Respostas nas perguntas anteriores)

17) $O$ que significa a família para o senhor (a senhora)?

A família é tudo para ela. Inclusive sua família da Espanha. Ela sempre escreve e telefona para eles. 
18) O senhor (a senhora) se sente brasileiro? Espanhol? Espanhol e brasileiro? Catalão?

(Ela se sente primeiro Espanhola - "Lo tengo dentro de mi!" - e um pouco brasileira.

18.1) Tem coisas que a senhora prefere o Brasil?

Sim, ela diz que prefere fazer compras aqui, pois os preços são mais baixos.

19) O que é ser espanhol? Ou catalão? Ou basco?

Ela respondeu à pergunta a seguir.

20) O que é ser valenciano? Madrileno? Catalão?

Ser sevilhano é ser alegre, dada com as pessoas e fácil de fazer amizades. 
ANEXO B - Questionário de pré-entrevista - Mari Carmen Acirón Rius

\section{ORIGEM}

1) Qual o Seu nome completo?

Mari Carmen Acirón Rius

2) Quando e onde nasceu?

20/11/1946

IMIGRAÇÃO

3) Quando imigrou para o Brasil?

Em 13/04/1957

4) Que idade o senhor (a senhora) tinha?

10 anos

5) Qual o motivo da imigração?

A situação da Espanha: a fome que eles passavam e a perseguição política ao seu pai.

\section{A VIAGEM}

6) Conte como foram os arranjos para a viagem. Quem te ajudou na viagem?

Sua mãe vendeu o relógio de carrilhão (de pé e canto) para pagar as despesas da viagem

7) Quem veio contigo?

A irmã e a mãe. O pai e o irmão já estavam no Brasil.

8) $O$ que trouxe contigo na bagagem? Trouxe alguns objetos de estimação que ainda te acompanham?

A máquina de costura da mãe e pouca roupa na bagagem. Muita ilusão, garra e força. 
9) Onde e como foi e desembarque?

Desembarcaram em Santos. Ela sentiu pavor por ver negros.pela primeira vez. Eles eram grandes e carregavam sacos nas costas.

10) Qual foi a sua primeira impressão sobre o Brasil ao desembarcar?

Ela se sentiu segura por ver o pai no desembarque.

\section{DA TRADIÇÃO AOS NOVOS COSTUMES}

11) Fale do período de adaptação: novo clima, novos costumes, novos hábitos, novos amigos, nova língua. Aspectos positivos e negativos.

A língua e os hábitos eram muito diferentes. "A gente não se entendia!"

12) $O$ que permaneceu da cultura e dos costumes de origem na sua família (língua, alimentação, religião etc.)?

A língua, a comida (pratos típicos) e a educação moral (respeito aos pais, às pessoas e a manter a honestidade).

13) O que foi incorporado da cultura da nova pátria?

O bom humor, a alegria, a comida brasileira e o jeitinho brasileiro.

\section{QUESTÃO DE IDENTIDADE E ESTABELECIMENTO DA VIDA NO BRASIL}

14) Mantém vínculo com o país de origem (cartas, telefonemas etc.)?

Tem vínculos com sua tia Lola, em Valência, e sua filha, Lolita.

15) Casou-se com espanhol(a) ou de outra nacionalidade?

Ela casou-se com um português.

16) Como o senhor (a senhora) constituiu sua família atual?

Pelo casamento com seu esposo, Sr. Henrique. Tiveram três filhos. Dois rapazes e uma moça.

17) O que significa a família para ao senhor (a senhora)?

A família significa tudo! 
18) O senhor (a senhora) se sente brasileiro? Espanhol? Espanhol e brasileiro? Catalão?

Ela se sente parte espanhola, parte brasileira e parte Valenciana.

19) $O$ que é ser espanhol?

É ser "pavio curto", ser apaixonado.

20) O que é ser valenciano? Madrileno?Catalão?

Ser valenciano é ter bom humor, fazer piada de tudo, usar muita ironia e piadas de duplo sentido. 
ANEXO C - Questionário de pré-entrevista - Margarita Riudoms Fernandez

\section{ORIGEM}

1) Qual o seu nome completo? E profissão?

Margarita Riudoms Fernandez, empresaria.

2) Quando e onde nasceu?

Espanha, Barcelona, em 10 de janeiro de 1941.

IMIGRAÇÃO

3) Quando imigrou para o Brasil?

1 de julho de 1962

4) Que idade o senhor (a senhora) tinha?

21 anos

5) Qual o motivo da imigração?

Novos horizontes.

\section{A VIAGEM}

6) Conte como foram os arranjos para a viagem. Quem te ajudou na viagem?

Normais sem ajuda de ninguém.

7) Quem veio contigo?

Meu marido e meu filho.

8) $O$ que trouxe contigo na bagagem? Trouxe alguns objetos de estimação que ainda te acompanham?

Sim, trouxe, mas tudo se acaba. 
9) Onde e como foi e desembarque?

Em Santos. Foi bom desembarcar... sempre é bom sinal na chegada.

10) Qual foi a sua primeira impressão sobre o Brasil ao desembarcar?

Péssima.

\section{DA TRADIÇÃO AOS NOVOS COSTUMES}

11) Fale do período de adaptação: novo clima, novos costumes, novos hábitos, novos amigos, nova língua. Aspectos positivos e negativos.

Tudo negativo, os primeiros 5 anos foram fatais!

12) $O$ que permaneceu da cultura e dos costumes de origem na sua família (língua, alimentação, religião etc.)?

Tudo, aos 21 anos se muda pouco.

13) O que foi incorporado da cultura da nova pátria?

Nada

QUESTÃO DE IDENTIDADE E ESTABELECIMENTO DA VIDA NO BRASIL

14) Mantém vínculo com o país de origem (cartas, telefonemas etc.)?

Sim

15) Casou-se com espanhol(a) ou de outra nacionalidade?

Duas vezes, com Espanhóis.

16) Como o senhor(a) constituiu sua família atual?

Com hábitos europeus.

17) O que significa a família para o senhor (a senhora)?

Tudo. 
18) O senhor (a senhora) se sente brasileiro? Espanhol? Espanhol e brasileiro? Catalão?

Catalã, Brasileira e Espanhola.

19) O que é ser espanhol? Ou catalão? Ou basco?

O que é ser Brasileiro????? Ser espanhol ou catalão é a mesma coisa.

20) O que é ser valenciano? Madrileno? Catalão?

Quase todas as pessoas amam a terra, o catalão adora. 
ANEXO D - Questionário de pré-entrevista - José Luis Blanco Goicoechea

\section{ORIGEM}

1) Qual o seu nome completo? E profissão?

José Luis Blanco Goicoechea, encadernador aposentado.

2) Quando e onde nasceu?

Em 11 de fevereiro de 1929. Nasceu em Madrid.

IMIGRAÇÃO

3) Quando imigrou para o Brasil?

Em 1958. Veio de navio.

4) Que idade o senhor (a senhora) tinha?

Ele tinha 29 anos.

5) Qual o motivo da imigração?

Estava cansado do regime franquista e queria sair da Espanha. Seus irmãos pensaram em sair da Espanha, por isso se motivou a sair de lá. Inicialmente, pensaram em emigrar para Argentina. Mas o navio parou no porto de Santos (Estado de São Paulo ), então resolveram descer e ver como era o Brasil. No início ele pensava que o Brasil era a terra do futuro! "Hoje eu vejo que é uma santa terra!"

\section{A VIAGEM}

6) Conte como foram os arranjos para a viagem. Quem te ajudou na viagem?

A viagem durou de 11 a 12 dias. Vieram de navio.

7) Quem veio contigo?

Seu irmão Enrique (Quique).

8) $O$ que trouxe contigo na bagagem? Trouxe alguns objetos de estimação que ainda te acompanham? 
Ele veio como um turista!Trazia apenas algumas roupas na mala e um relógio ômega de ouro!

9) Onde e como foi e desembarque?

No porto de Santos.

10) Qual foi a sua primeira impressão sobre o Brasil ao desembarcar?

"Deplorable!!! Se me vino el mundo a los pies!"

Quando foi à Avenida Ipiranga, se impressionou com os prédios altos. Mas também viu a miséria!

\section{DA TRADIÇÃO AOS NOVOS COSTUMES}

11) Fale do período de adaptação: novo clima, novos costumes, novos hábitos, novos amigos, nova língua. Aspectos positivos e negativos.

A adaptação foi muito dura! Estranhou o clima, o idioma, as comidas, tudo! Aspecto positivo: "conocer a tu madre!"

12) $O$ que permaneceu da cultura e dos costumes de origem na sua família (língua, alimentação, religião etc.)?

Ele tem passado a cultura espanhola aos filhos e para a esposa, principalmente por meio da comida e do idioma.

13) O que foi incorporado da cultura da nova pátria?

Nada

\section{QUESTÃO DE IDENTIDADE E ESTABELECIMENTO DA VIDA NO BRASIL}

14) Mantém vínculo com o país de origem (cartas, telefonemas etc.)?

"Mantenho contato, pois tenho um irmão, cunhada e sobrinhos". Ele telefona de vez em quando.

15) Casou-se com espanhol(a) ou de outra nacionalidade?

Casou-se com uma brasileira, bisneta de italianos. 
16) Como o senhor(a) constituiu sua família atual?

Ele conheceu a sua esposa na fábrica onde trabalhava. Namoraram pouco tempo e casaram-se. Foram morar na casa que o sogro construiu no terreno onde morava. Moraram lá por sete anos. Enquanto moravam lá, compraram um terreno no mesmo bairro e construíram uma casa. Moraram lá por 35 anos. Depois os filhos casaram e a casa se tornou grande para o casal. Então mudaram para um apartamento.

17) O que significa a família para o senhor (a senhora)?

A família é tudo!

18) O senhor (a senhora) se sente brasileiro? Espanhol? Espanhol e brasileiro? Catalão?

"Soy espanhol!!! Hasta la medula!"

19) O que é ser espanhol? Ou catalão? Ou basco?

20) O que é ser valenciano? Madrileno? Catalão?

Ele se diz madrileno. Acrescenta com o ditado: "De Madrid al cielo con un agujerito para verlo". 


\section{ANEXO E - Questionário das entrevistas para gravação}

\section{CUESTIONÁRIO - ENTREVISTAS PARA GRABACIÓN}

\section{1) Origen}

1.1) ¿Cuál es tu nombre y apellidos?

1.2) ¿Cuándo y dónde naciste? ¿Cómo era tu ciudad? ¿Grande o pequeña?

1.3) ¿Cuántas personas había en tu familia?

1.4) ¿En qué trabajaban tu padre y tu madre?

1.5) ¿Cómo fue tu niñez? ¿en cuál escuela estudiabas. ¿Cómo fue tu adolescencia?

\section{2) Inmigración}

2.1) ¿Cuándo inmigraste a Brasil? ¿Con qué edad?

2.2) ¿Porqué viniste a Brasil? (Resaltar el mundo del trabajo).

2.3) ¿Pensabas en irte a otro país?

2.4) ¿Qué sabias sobre Brasil en la época?

\section{3) El viaje}

3.1) ¿Cómo fueron los preparativos para el viaje? ¿Alguien te ayudó?

3.2) ¿Con quién has venido?

3.3) ¿Qué cosas trajiste contigo? ¿Algún objeto -personal?

3.4) ¿Cómo ha sido el viaje? Transporte, rutina, alimentación, para dormir...

3,5) ¿En qué puerto desembarcaste y cómo era el lugar?

3.6) ¿Qué sentiste al desembarcar? ¿Cuál fue la primera impresión respecto a Brasil?

\section{4) De la tradición a las nuevas costumbres}

4.1) ¿Desde que llegaste mantienes contacto con personas en España?

4.2) ¿Fue difícil acostumbrarse aquí? ¿Cómo fue la adaptación al clima, nuevas costumbres, nuevos hábitos, otro idioma.

4.3) ¿Conviviste con inmigrantes españoles? ¿Y con inmigrantes de otras nacionalidades?

4.4) ¿Habían escuelas para inmigrantes y sus hijos? ¿Quiénes las mantenían?

4.5) ¿Cómo vivían los niños?

4.6) ¿Dónde fuiste a trabajar? 


\section{5) La (s) identidades culturales}

5.1) ¿Todavía tienes familiares o amigos en España?

5.2) ¿Te casaste con español o con persona de otra nacionalidad?

5.3) ¿Ya volviste a tu tierra ¿Qué pasó?

5.4) ¿Hoy te sientes español (a), valenciano (a), catalán o brasileño(a)?

$5.5)$ ¿Con lo qué te identificas más en la cultura brasileña?

5.6) ¿Cuáles son las cosas buenas y las malas en Brasil?

5.7) ¿Algún hábito o costumbre en Brasil te parecen raros?

5.8) ¿Para ti, qué es/significa ser español?

5.9) ¿Cuáles son los colores de España?

5.10) ¿Cuáles son los olores de España?

5.11) ¿Cuéntanos algunos recuerdos felices de España (opción- hacer esta pregunta articulando con los sonidos, olores y colores).

\section{SUBTEMAS TRANSVERSALES P/ INSERIR A LO LARGO DE LOS TEMAS:}

- Sueños

- Recuerdos felices

- Sensaciones - olores, sabores y colores que recuerdan España

- Aficiones

- Amores

- provocaciones (fútbol, etc.)

- Chistes de español.

- Anécdotas que haya vivido 
ANEXO F - Ordem do dia - primeira gravação - Mari Carmen Acirón Rius

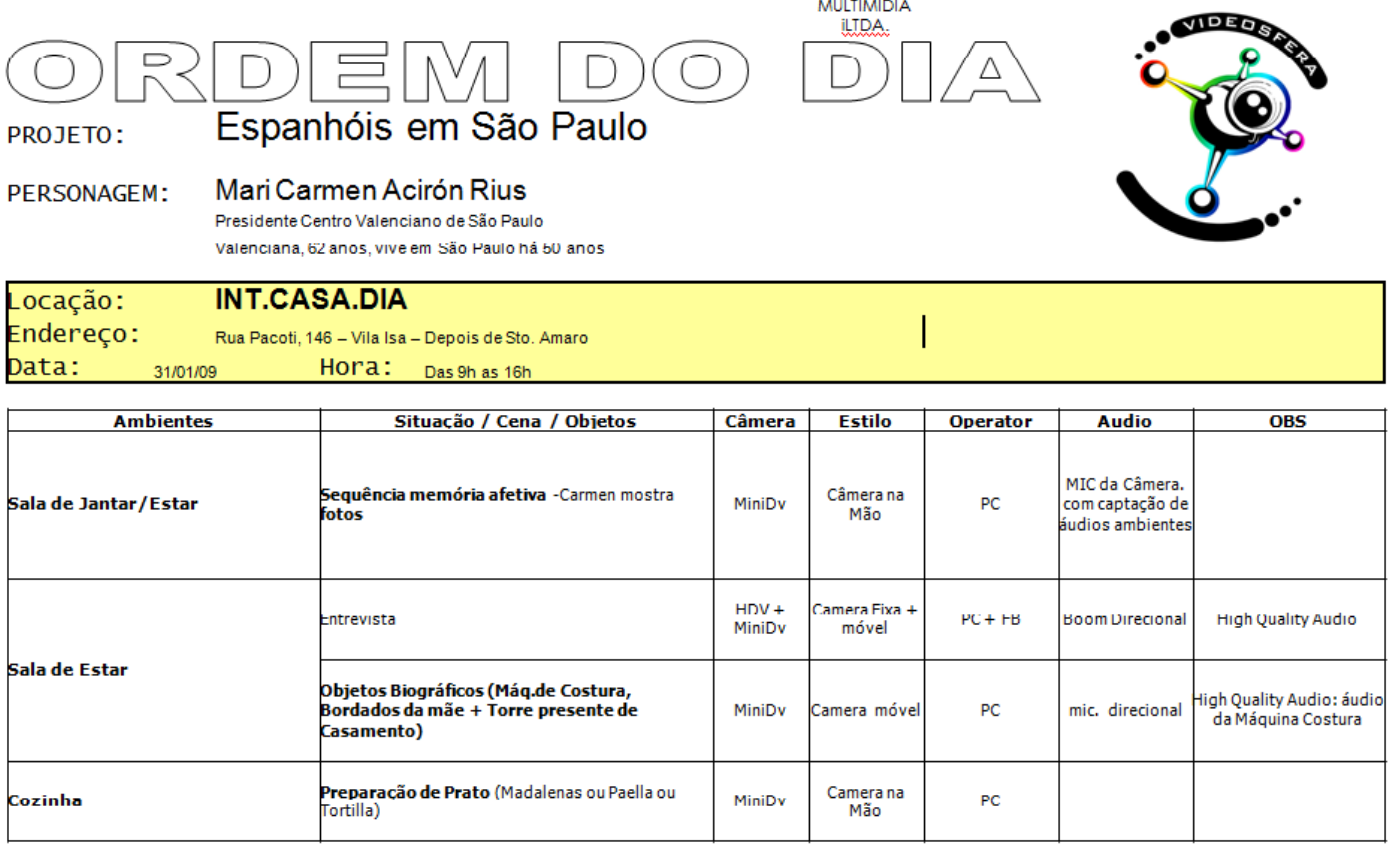




\section{ANEXO G - Ordem do dia - segunda gravação - José Luis Blanco Goicochea}

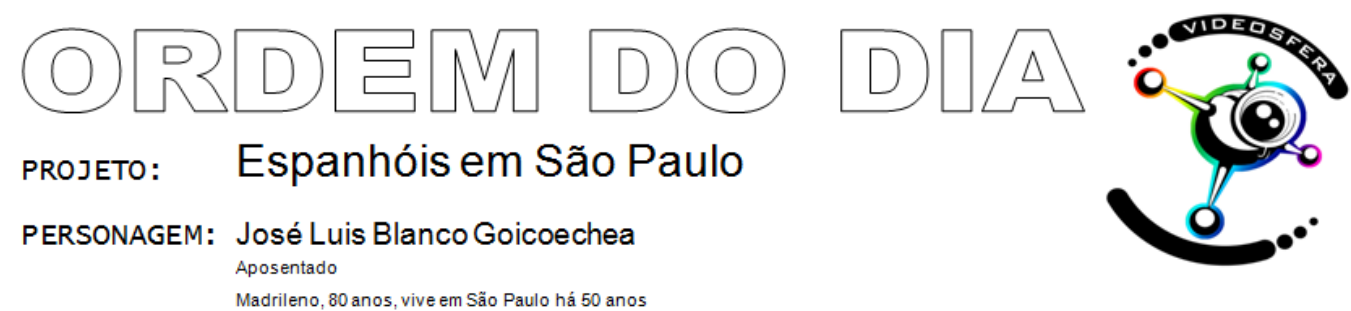

Locação: INT.APARTAMENTO.DIA

Endereço: R. Willis Roberto Banks, 401 - Bl 03 Apto 74

Data: $06 / 02 / 09$ Hora: Das $9 \mathrm{~h}$ as $16 \mathrm{~h}$

\begin{tabular}{|c|c|c|c|c|c|c|}
\hline Ambientes & Situação / Cena / Objetos & Câmera & Estilo & Operator & Audio & OBS \\
\hline Sala de Jantar/Estar & $\begin{array}{c}\text { Quadro Guernica / Castanholas / Fotos } \\
\text { / Outros Objetos }\end{array}$ & MiniDv & $\begin{array}{c}\text { Camera na } \\
\text { Mão }\end{array}$ & VANDERLEI & \begin{tabular}{|c|} 
MIC da \\
Camera. sem \\
captação de \\
sons \\
ambientes \\
\end{tabular} & $\begin{array}{c}\text { Máquina Fotográfica } \\
\text { !!!!! }\end{array}$ \\
\hline \multirow{3}{*}{ Sala de Estar } & Entrevista & \multirow{2}{*}{$\begin{array}{l}\mathrm{HDV}+ \\
\text { MiniDv }\end{array}$} & \multirow{2}{*}{$\begin{array}{c}\text { Camera Fixa } \\
+ \text { móvel }\end{array}$} & \multirow{2}{*}{$\begin{array}{l}\text { PC: PMédio } \\
\text { VD: Detalhe }\end{array}$} & \multirow{2}{*}{$\begin{array}{l}\text { Boom } \\
\text { Direcional }\end{array}$} & \multirow[b]{2}{*}{ High Quality Audio } \\
\hline & $\begin{array}{l}\text { Momento Memória Afetiva: Seleção de } \\
\text { livros em mau estado para JL restaurá-los }\end{array}$ & & & & & \\
\hline & $\begin{array}{l}\text { Objetos Biográficos (Boneca Espanhola / } \\
\text { Mapas / Objetos de profissão: } \\
\text { Espátula de Osso, dicionário } \\
\text { ilustrado) }\end{array}$ & MiniDv & $\begin{array}{c}\text { Camera na } \\
\text { Mão }\end{array}$ & PC & & \\
\hline Cozinha & $\begin{array}{l}\text { Preparação de Prato Sentimental: } \\
\text { Tortilla }\end{array}$ & MiniDv & $\begin{array}{c}\text { Camera na } \\
\text { Mão }\end{array}$ & VANDERLEI & & \\
\hline
\end{tabular}




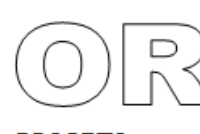

PROJETO:

\section{Espanhóis em São Paulo}

PERSONAGEM: Margarita Riudoms Fernandez

Comerciante. Loja de Biquínis

Catalã (Barcelona-Catalunha) 69 anos, Vive em São Paulo há 49 anos
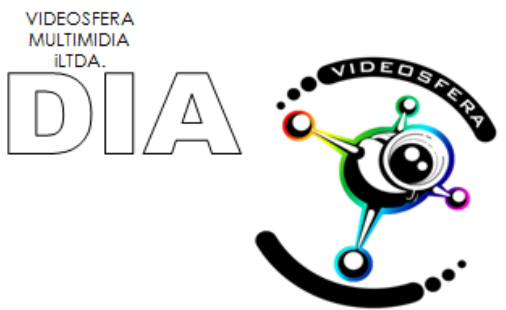

Locação:

Endereço:

INT.CASA.DIA

bata:

Rua Cel. Tupi Caldas, 37 - Agua Fria - Santana ZN

।

\begin{tabular}{|c|c|c|c|c|c|c|}
\hline Ambientes & Situação / Cena / Objetos & Câmera & Estilo & Operator & Audio & OBS \\
\hline Quarto & $\begin{array}{l}\text { Sequência: memória afetiva mostra livros e } \\
\text { discos }\end{array}$ & & & & & \\
\hline Na Sala & 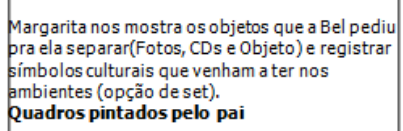 & Minidv & $\begin{array}{l}\text { Camera } \\
\text { móvel }\end{array}$ & A Definir & $\begin{array}{c}\text { Mic da Camera. } \\
\text { com captaç̃̃o } \\
\text { de sons } \\
\text { ambientes }\end{array}$ & $\begin{array}{l}\text { Definir Planos de } \\
\text { Câmera }\end{array}$ \\
\hline Audio & $\begin{array}{l}\text { Conversa inicial com Fábio sobre músicas de que } \\
\text { ela gosta. }\end{array}$ & HDV & $\begin{array}{c}\text { Registrar } \\
\text { imagem se } \\
\text { possivel }\end{array}$ & PC Fábio & Direcional & $\begin{array}{l}\text { 1. Perto (Close) } \\
\text { 2. P.A (Médio) } \\
\text { 3. (Zoom In/Z.OO) }\end{array}$ \\
\hline \multirow{2}{*}{ Sala de Estar } & Entrevista & $\begin{array}{l}\text { HDV }+ \\
\text { MiniDv }\end{array}$ & $\begin{array}{c}\text { Camera Fixa } \\
+ \text { móvel }\end{array}$ & $P C+F B$ & Direcional & High Quality Audio \\
\hline & Objeto Biográfico: Livro de poesias em catalẫ & MiniDv & Camera móvel| & $\mathrm{PC}$ & Direcional & $\begin{array}{l}\text { High Quality Audio: } \\
\text { som }\end{array}$ \\
\hline
\end{tabular}




\section{ANEXO I - Ordem do dia - quarta gravação - Carmen Baena Fernandez}

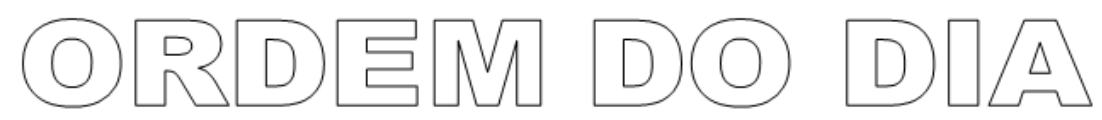

\section{PROJETO: $\quad$ Espanhóis em São Paulo}

PERSONAGEM: Carmen Baena Fernandez

Dona de Casa

Sevilhana, 74 anos, vive em Săo Paulo há 64 anos

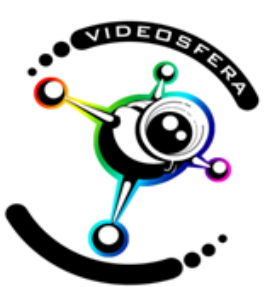

Locação: INT.CASA.DIA

Endereço: $\quad$ Rua Julio Porto Carrero, 35 - Jd. Regina

bata: 28/03/09 Hora: A partir das 14h

\begin{tabular}{|c|c|c|c|c|c|c|}
\hline Ambientes & Situação / Cena / Objetos & Câmera & Estilo & Operador & Audio & OBS \\
\hline \multirow{5}{*}{$\begin{array}{l}\text { Sala de Jantar/Estar Registrar } \\
\text { essa sequência já no lugar que se definiu } \\
\text { para gravar a entrevista. Vanderlei } \\
\text { egistra a cena (câm. Móvel) enquanto } \\
\text { CC monta o set com Carmen sentada. }\end{array}$} & $\begin{array}{l}\text { Sequência Construção da Personagem: Não } \\
\text { paverá }\end{array}$ & \multirow{5}{*}{ MiniDv } & \multirow{5}{*}{$\begin{array}{l}\text { Camera } \\
\text { móvel }\end{array}$} & \multirow{5}{*}{ VANDERLEI } & \multirow{5}{*}{$\begin{array}{l}\text { Mic } \\
\text { acoplado à } \\
\text { mini DV }\end{array}$} & \multirow{5}{*}{$\begin{array}{l}\text { Bel e Fábio comandam } \\
\text { entrevistas e assuntos } \\
\quad \text { com Carmen }\end{array}$} \\
\hline & Sequência Memória Afetiva: Mostra livro de Sevilla & & & & & \\
\hline & $\begin{array}{l}\text { Músicas: FÁBIO ENTREVISTA } \\
\text { Ela gosta de Músicas Espanholas, Boleros e Sertanejas. }\end{array}$ & & & & & \\
\hline & $\begin{array}{l}\text { Objeto(s) Biográfico(s): } \\
\text { xale de bailarina Sevilhana- mantón de manilla e } \\
\text { leque }\end{array}$ & & & & & \\
\hline & $\begin{array}{l}\text { Fotos: Não há fotos da época em que ela chegou ao } \\
\text { Brasil. Verificar fotos de familia em álbuns, nas paredes da } \\
\text { Fala, atenção para o Rack da TV. }\end{array}$ & & & & & \\
\hline Sala de Estar & Sequencia entrevista - câm. Fixa & $\begin{array}{l}\text { HDV + } \\
\text { MiniDv } \\
\text { (c/ monopé) }\end{array}$ & & $\begin{array}{l}\text { PC: PMédio } \\
\text { VD: Detalhe }\end{array}$ & Mic. Direcional & High Quality Audio \\
\hline
\end{tabular}

NOTES: 